Departamento de Computação e Matemática

Faculdade de Filosofia Ciências e Letras de Ribeirão Preto (FFCLRLP)

Universidade de São Paulo (USP)

DISSERTAÇÃO APRESENTADA AO PROGRAMA INTERUNIDADES EM

BIOINFORMÁTICA DA UNIVERSIDADE DE SÃO PAULO PARA OBTENÇÃO DO TÍTULO DE MESTRE EM CIÊNCIAS

\title{
ANÁLISE GÊNICA DE COMORBIDADES A PARTIR DA INTEGRAÇÃO DE DADOS EPIDEMIOLÓGICOS
}

\author{
Acadêmica: Karla Ferraz Néto
}

Orientador: Prof. Dr. Evandro Eduardo Seron Ruiz - FFCLRP, USP

Co-Orientadores: Prof. Dr. Victor Evangelista Ferraz - FMRP, USP

Prof. Dr. Domingos Alves - FMRP, USP

São Paulo 
Karla Ferraz Néto

\section{ANÁLISE GÊNICCA DE COMORBIDADES A PARTIR DA INTEGRAÇÃO DE DADOS EPIDEMIOLÓGICOS}

Este exemplar corresponde à redação final de dissertação/tese devidamente corrigida e defendida por Karla Ferraz Néto e aprovada pela Comissão Julgadora.

Área de Concentração: Bioinformática

Banca Examinadora:

- Prof. Dr. Evandro Eduardo Seron Ruiz (orientador) - FFCLRP - USP

- Prof. Dr. Alexandre Souto Martinez - FFCLRP - USP

- Prof. Dr. Helena Paula Brentani - FMUSP - USP 


\section{Resumo}

\section{NÉTO, K. F. Análise Gênica de Comorbidades a partir da Integração de Dados}

Epidemiológicos. 2014. Dissertação de Mestrado - Faculdade de Filosofia Ciências e Letras de Ribeirão Preto, Ribeirão Preto, São Paulo, 2014.

A identificação de genes responsáveis por doenças humanas pode fornecer conhecimentos sobre mecanismos patológicos e fisiológicos que são essenciais para o desenvolvimento de novos diagnósticos e terapias. Sabemos que uma doença é raramente uma consequência de uma anormalidade num único gene, porém reflete desordens de uma rede intra e intercelular complexa.

Muitas metodologias conhecidas na Bioinformática são capazes de priorizar genes relacionados a uma determinada doença. Algumas abordagens também podem validar a pertinência ou não destes genes em relação à doença estudada. Uma abordagem de priorização de genes é a investigação a partir de doenças que acometem pacientes ao mesmo tempo, as comorbidades.

Existem muitas fontes de dados biomédicos que podem ser utilizadas para a coleta de comorbidades. Desta forma, podemos coletar pares de doenças que formam comorbidades epidemiológicas e assim analisar os genes de cada doença. Esta análise serve para expandirmos a lista de genes candidatos de cada uma dessas doenças e justificarmos a relação gênica entre essas comorbidades.

O objetivo principal deste projeto é o de integração dos dados epidemiológicos e genéticos para a realização da predição de genes causadores de doenças. Isto se dará através do estudo de comorbidade destas doenças.

Palavras-chave: predição de genes, integração de dados, comorbidade. 


\section{Abstract}

\section{NÉTO, K. F. Comorbidities Genetic Analysis from Epidemological Data Integra-}

tion. 2014. Master's thesis - Faculdade de Filosofia Ciências e Letras de Ribeirão Preto, Ribeirão Preto, São Paulo, 2014.

The identification of genes responsible for human diseases can provide knowledge about pathological and physiological mechanisms that are essential for the development of new diagnostics and therapeutics. It is known that a disease is rarely a consequence of an abnormality in a single gene, but reflects complex intra and intercellular network disorders.

Many methodologies known in Bioinformatics are able to prioritize genes related to a particular disease. Some approaches can also validate how appropriate or not these genes are relative to a disease. An approach for prioritizing genes is the research from diseases affecting patients at the same time, i.e. comorbidities.

There are many sources of biomedical data that can be used to collect comorbidities and analyse genes of each disease. We can also expand the list of candidate genes for each singular disease and justify the genetic relationship of these comorbidities.

The main objective of this project is the integration of epidemiologic and genetic data to perform the prediction of causing genes through the study of comorbidity of these illnesses.

Keywords: gene prediction, data integration, comorbidity. 


\section{Sumário}

Lista de Figuras $\quad$ vii

Lista de Tabelas $\quad$ ix

1 Introdução 1

1.1 Contexto e Motivação . . . . . . . . . . . . . . . . 1

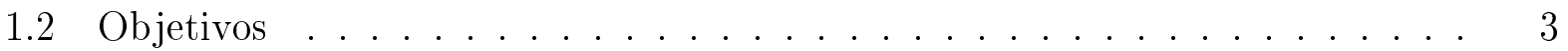

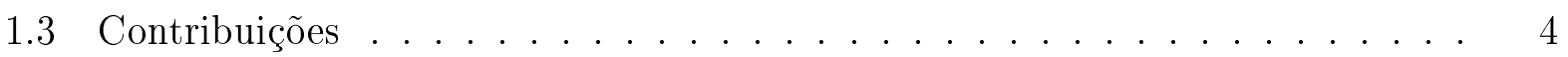

1.4 Organização do Trabalho . . . . . . . . . . . . . . . . . . 4

2 Estado da Arte $\quad 6$

2.1 Doenças Complexas . . . . . . . . . . . . . . . . . . 6

2.2 Métodos de Predição de Genes . . . . . . . . . . . . . . . . . 8

2.3 Considerações . . . . . . . . . . . . . . . . . . . . . 11

3 Conceitualização 12

3.1 Proposta de Método para Predição de Genes . . . . . . . . . . . . . . . . . 12

3.2 Coleta de Genes . . . . . . . . . . . . . . . . . . . 13

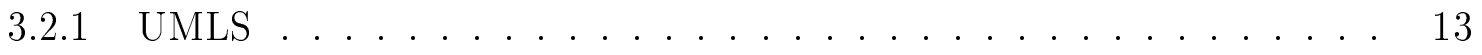

3.3 Gene Ontology . . . . . . . . . . . . . . . . . . 17

3.3 .1 Comparação entre Genes . . . . . . . . . . . . . . . . . . . . 19

3.4 Considerações . . . . . . . . . . . . . . . . . . . . . . . 23

4 Método para Predição de Genes $\quad 24$

4.1 Pipeline-Etapas do Projeto . . . . . . . . . . . . . . . . . 24

4.2 Coleta de Dados-Base Hospitalar . . . . . . . . . . . . 25 
4.2.1 Confiabilidade dos Dados . . . . . . . . . . . . . . . 25

4.3 Filtragem dos Dados - Cálculo de Comorbidade . . . . . . . . . . . . 26

4.4 Triangulação CID-10-UMLS-OMIM . . . . . . . . . . . . . 27

4.5 Mapeamento OMIM-Símbolo de Genes . . . . . . . . . . . . . . . . . 28

4.6 Similaridade Semântica . . . . . . . . . . . . . . . . . . . . . 29

4.7 Visualização Gráfica da Matriz de Similaridade . . . . . . . . . . . . 31

4.8 Validação dos Métodos . . . . . . . . . . . . . . . . . . . . . 32

5 Resultados $\quad 33$

5.1 Resultados da Filtragem de Dados . . . . . . . . . . . . . . . . 33

5.2 Validação dos Resultados . . . . . . . . . . . . . . . . . . 34

5.2 .1 Esquizofrenia $\mathrm{x}$ Autismo . . . . . . . . . . . . . 34

5.2 .2 Macrocefalia x Autismo . . . . . . . . . . . 37

5.3 Resultados do Estudo de Caso . . . . . . . . . . . . . . . . . . 38

5.3.1 Fenda Palatina x Coxartrose não especificada . . . . . . . . . . . 42

5.3.2 Fenda Palatina x Sinusite crônica não especificada . . . . . . . . . . . 43

5.3 .3 Fenda Palatina x Apneia do Sono . . . . . . . . . . . . . 45

5.3.4 Fenda Palatina x Osteomielite . . . . . . . . . . . . 46

5.3.5 Fenda Palatina x Testículo Não Descido . . . . . . . . . . . . 48

5.3.6 Fenda Palatina x Espinha Bífida . . . . . . . . . . . . . . . 49

5.3.7 Fenda Palatina $x$ Polidactilia . . . . . . . . . . . . . 51

5.3 .8 Fenda Palatina x Sindactilia . . . . . . . . . . . . . 53

5.4 Discussão dos Resultados . . . . . . . . . . . . . . . . . . . 53

6 Considerações Finais $\quad 56$

6.1 Conclusões . . . . . . . . . . . . . . . . . . 56

6.2 Dificuldades Encontradas . . . . . . . . . . . . . . 56

6.3 Trabalhos Futuros . . . . . . . . . . . . . . . . 57

$\begin{array}{ll}\text { A Laudo AIH } & 58\end{array}$

$\begin{array}{ll}\text { Referências Bibliográficas } & 60\end{array}$ 


\section{Lista de Figuras}

2.1 Efeito pleiotrópico de genes associados a causas de múltiplas doenças complexas. 7

3.1 Fluxo básico do método a ser proposto. . . . . . . . . . . . . . . 12

3.2 Mapeamento de códigos CID-10 em OMIM através dos conceitos referentes da UMLS. . . . . . . . . . . . . . . . . . . . . 17

3.3 Organização relacional do GO . . . . . . . . . . . . . . . . . . . 19

3.4 Exemplo de probabilidades e IC de termos do Gene Ontology. . . . . . . . . 23

4.1 Pipeline de execução das etapas do projeto. . . . . . . . . . . . . . 24

4.2 Fluxo de chamada de funções para o mapeamento CID-10-OMIM. . . . . . . 28

4.3 Organização estrutural do arquivo morbidmap. . . . . . . . . . . . . . 29

4.4 Matriz de Similaridade Semântica entre os genes representados por identificadores Entrez. Os identificadores 379, 10584 e 8625 correspondem respectivamente aos símbolos de genes ARLD4, COLEC10 e RFXANK. . . . . . . . 31

5.1 Visualização Bidimensional de distâncias entre os genes relacionados à Esquizofrenia e ao Autismo. . . . . . . . . . . . . . . . . . 36

5.2 Via de interação entre os genes IFNG e DRD3. . . . . . . . . . . . 37

5.3 Visualização Bidimensional de distâncias entre os genes relacionados à Macrocefalia e Autismo. O destaque em roxo mostra a associação do gene PTEN tanto para Macrocefalia como para Autismo. . . . . . . . . . . . . . . . 40

5.4 Visualização Bidimensional de distância entre os genes relacionados à Fenda Palatina e Coxartrose. . . . . . . . . . . . . . . . . . 44

5.5 Via de interação entre os genes COL9A3 e COL11A1. . . . . . . . . 45

5.6 Visualização Bidimensional de distâncias entre os genes relacionados à Fenda Palatina e Sinusite. . . . . . . . . . . . . . . . . . 46 
5.7 Visualização Bidimensional de distâncias entre os genes relacionados à Fenda Palatina e Apneia do Sono. . . . . . . . . . . . . . . . . . . . 47

5.8 Visualização Bidimensional de distâncias entre os genes relacionados à Fenda Palatina e Osteomielite. . . . . . . . . . . . . . . . . . . 48

5.9 Via de interação entre os genes NTRK1, TCOF1, UBB. . . . . . . . . . . 49

5.10 Visualização Bidimensional de distâncias entre os genes relacionados à Fenda Palatina e Testículo Não Descido. . . . . . . . . . . . . . . . . . . . 50

5.11 Visualização Bidimensional de distâncias entre os genes relacionados à Fenda Palatina e Espinha Bífida. . . . . . . . . . . . . . . . . . . 51

5.12 Visualização Bidimensional de distâncias entre os genes relacionados à Fenda Palatina e Polidactilia. . . . . . . . . . . . . . . . . . 52

5.13 Via de interação entre os genes TFAP2A e os associados à Fenda Palatina. 53

5.14 Visualização Bidimensional de distância entre os genes relacionados à Fenda Palatina e Sindactilia. . . . . . . . . . . . . . . . . . . 54

A.1 Laudo de Solicitação de Autorização de Internação Hospitalar. . . . . . . . . 59 


\section{Lista de Tabelas}

3.1 Categorização de Terminologias UMLS. . . . . . . . . . . . . . 15

5.1 Valores pré-filtragem de comorbidades. . . . . . . . . . . . . . 33

5.2 Valores pós-filtragem de comorbidades. . . . . . . . . . . . . . . . 34

5.3 Evidência de comorbidade entre Esquizofrenia e Autismo nos registros de internações hospitalares. . . . . . . . . . . . . . . . . . 34

5.4 Relação de genes resposáveis para Esquizofrenia e Autismo. . . . . . . . . . 35

5.5 Relação de genes resposáveis para Macrocefalia e Autismo. . . . . . . . . . . 39

5.6 Principais doenças associadas à Fenda Palatina (Q35). . . . . . . . . . . 42

5.7 Genes relacionados às doenças. . . . . . . . . . . . . . . . . 43 


\section{Capítulo 1}

\section{Introdução}

Este capítulo visa contextualizar e descrever motivações e objetivos para a realização deste projeto de pesquisa.

\subsection{Contexto e Motivação}

Um dos principais desafios da bioinformática é a identificação de fatores causais de doenças complexas humanas. Tais doenças são conhecidas por apresentarem múltiplas variações genéticas e fatores ambientais. Elas são tipicamente causadas pela combinação de perturbações genéticas ou não genéticas que podem variar entre pacientes e desregular um mesmo componente do sistema celular. A multiplicidade de fatores e variações que causa essas doenças dificulta a identificação de suas origens e seus possíveis tratamentos (KIM; WUCHTY; PRZYTYCKA, 2011).

A identificação de genes responsáveis por doenças complexas humanas fornece conhecimento sobre mecanismos patológicos e fisiológicos que são essenciais para o desenvolvimento de novos diagnósticos e terapias (GUDIVADA et al., 2008). O estudo da identificação de conjuntos corretos de genes para análise de mutações associadas a uma doença em estudo, é chamado de predição de genes (AERTS et al., 2006).

Uma anormalidade genética específica não está restrita à atividade do produto gênico que o carrega. Ela pode se propagar para as ligações de sua rede gênica e alterar a atividade de outros produtos gênicos que não apresentam mutação (BARABASI; GULBAHCE; LOSCALZO, 2011). Desta forma, usando uma perspectiva proteômica, podemos afirmar que a ocorrência de um par de doenças num mesmo indivíduo pode estar relacionado geneticamente, pois proteínas associadas às doenças podem estar ligadas aos mesmos processos biológicos de ambas as doenças (HIDALGO et al., 2009).

Esforços para se mapear localizações de doenças humanas, genética e fisicamente, foram seguidas pela recente clonagem de muitos genes relacionados a doenças e estudos de associa- 
ção de genômica ampla. Isso gerou uma lista extensa de associações de pares doenças-genes. Além disso, mapeamentos de interações proteína-proteína em humanos, junto com mapeamentos de redes metabólicas e regulatórias, aumentaram o detalhamento do relacionamento entre os genes causadores de doenças (GOH; CUSICK, 2007). Devido à facilidade de acesso a esses dados, há uma grande gama de pesquisas relacionadas à predição de genes. Elas levam em conta diversas abordagens que utilizam essas informações de relacionamentos de genes associados a doenças.

Em pesquisas recentes, como a realizada por (ROQUE et al., 2011), foram extraídas correlações entre doenças a partir de registros eletrônicos de pacientes. Essas extrações foram feitas para estender informações de relações entre as doenças recorrentes com dados gênicos já reconhecidos como causadores. A partir desta extensão, foi possível identificar novos genes que podem estar relacionados à associação de doenças registradas em históricos clínicos.

Pode-se perceber que, enquanto o progresso das frentes gênicas e proteômicas é impressionante, não nos damos conta de que muitas fontes disponíveis de dados apresentam atualizações extensivas e contínuas de informações fenotípicas humanas, conhecidas como os históricos clínicos de pacientes. Esses conjuntos de dados contêm informações de associações e progressões de doenças de milhares de pacientes. Na realidade da maioria dos hospitais no Brasil, realizar um estudo semelhante ao trabalho realizado por (ROQUE et al., 2011), ainda é um passo distante, dado que para estes hospitais faltam dados sobre as características genéticas dos pacientes. No entanto, o Sistema Único de Saúde (SUS) proporciona um grande conjunto de outras informações, como por exemplo, o registro de ocorrências de internações hospitalares.

Surge então a questão: será que na realidade brasileira da maioria dos hospitais públicos, utilizando estes registros do SUS, pode-se obter dados fenotípicos dos pacientes que podem auxiliar o trabalho de predição gênica?

Acreditamos que essas informações sobre internações hospitalares podem ser utilizadas em conjunto com os dados moleculares e genéticos para o auxílio a descobertas de origens moleculares de doenças. Um dado relevante que pode ser estudado a partir desses registros de internações é o estudo das comorbidades - a presença de uma ou mais complicações (ou doenças) em adição a uma doença ou complicação primária que o paciente apresenta (GOH; CUSICK, 2007). Através do estudo detalhado de doenças e suas principais comorbidades podemos tentar identificar os principais genes associados às duas doenças. Assim, podemos também verificar se estes genes associados aos mesmos processos biológicos são também considerados responsáveis por doenças vistas em comorbidades comuns (LEE et al., 2008). Esta verificação poderá contribuir com a busca dos genes que são associados às comorbidades e assim poderemos desenvolver estudos das causas e associações genéticas das mesmas.

A Ciência da Computação aplicada à Saúde virá a ser um facilitador para este projeto, podendo prover ao profissional da Saúde um auxílio no apoio à tomada de decisão. Com 
o processamento do grande volume de dados hospitalares e enorme conhecimento presente na literatura, o acesso à informação se tornou mais complexo. A partir de metodologias computacionais, podemos auxiliar o profissional da saúde a acessar os dados com mais facilidade. Será possível também relacionar dados fenotípicos e genéticos que estão disponíveis em bancos de dados de grande abrangência de forma eficiente. Ou seja, o profissional poderá ter acesso a possíveis novos conhecimentos sobre as associações de doenças, suas causas e relações genéticas.

Este projeto propõe, em uma primeira etapa, a construção de um método de análise epidemiológica de registros dos hospitais públicos do Brasil. Estes registros são provenientes dos documentos de Autorização de Internação Hospitalar (AIH), mantidos pelo Sistema de Informações Hospitalares do SUS, do Ministério da Saúde. Eles registram dois diagnósticos por internação (principal e secundário), codificados pelo sistema CID-10 (Classificação Internacional de Doenças, versão 10). A partir da análise de pares de doenças baseado em registros AIH num período de 13 anos, ou seja, entre 1998 e 2011 realiza-se a análise dos potenciais genes responsáveis por tais doenças. Para tanto, utilizam-se as informações fenotípicas e genotípicas relacionadas na base de dados Online Mendelian Inheritance in Man (OMIM) (OMIM, 2014). Em uma segunda etapa, complementaremos estas coleções de genes associados às doenças, realizando uma análise das inter-relações destes conjuntos a partir de estudos de Similaridade Semântica. Nosso objetivo é associar novos genes relacionados a cada doença através de relações ontológicas de processos biológicos dos termos referentes a esses genes e que já foram previamente anotados na literatura.

\subsection{Objetivos}

O objetivo principal deste projeto de pesquisa é desenvolver um método de busca de genes candidatos, ou seja, de predição gênica, para doenças complexas. Este método utiliza um conhecimento à priori de comorbidades, assim como o conhecimento integrado de bancos de dados públicos do SUS e métodos que utilizam vocabulários controlados.

Como objetivos secundários, temos:

- avaliar o uso de registros de comorbidades do Sistema de Informações Hospitalares do SUS para priorização de comorbidades a serem exploradas;

- avaliar se doenças que apresentam alta comorbidade compartilham genes candidatos;

- avaliar a pertinência das relações gênicas encontradas através de medidas de Similaridade Semântica entre os genes, usando as anotações ontológicas dos processos biológicos dos quais estes genes participam;

- propor um método computacional de análise baseado no uso dos códigos de doenças 
estruturados para a busca dos genes candidatos. Este método será uma alternativa à realidade dos nossos sistemas de registros públicos, onde somente os códigos de doenças são disponibilizados.

Visando estes objetivos, buscaremos responder a algumas questões de pesquisa:

- Como estudar as relações e associações de doenças a partir de uma amostra de dados de registros do SUS?

- Como avaliar a qualidade desses dados e utilizar somente aqueles que apresentem significância estatística para andamento do estudo?

- Como esses resultados podem nos auxiliar na pesquisa de relações gênicas entre patologias que compartilham comorbidades?

- Como lidar com problemas de ausência de mapeamento direto entre doença-genes candidatos?

\subsection{Contribuições}

As principais contribuições deste trabalho foram as seguintes:

- levantamento bibliográfico, com o estudo das doenças complexas e o relacionamento destas com a pleiotropia dos genes. Além disso, realiza-se o estudo dos métodos de predição de genes;

- proposição e avaliação de um método capaz de realizar a predição de genes, através da integração de dados de comorbidades e de diversas ferramentas comumente utilizadas na comunidade da bioinformática, como o OMIM, UMLS e o Gene Ontology;

- validação dos resultados através da busca de evidências na literatura que comprovem associação de genes-doenças;

- contribuição para a publicação de um artigo para o Workshop de Informática Médica de 2012 (NETO et al., 2012) e para a submissão de outro artigo para o Congresso Brasileiro de Informática em Saúde de 2014.

\subsection{Organização do Trabalho}

Esta dissertação está dividida em 6 capítulos. Neste primeiro capítulo abordamos a contextualização do problema referente à predição gênica e descrevemos os objetivos do projeto 
de pesquisa. No Capítulo 2, discutiremos pontos sobre doenças complexas, a importância da identificação de origens genéticas das mesmas, além da definição de métodos comumente utilizados no trabalho de predição de genes candidatos à doenças.

No Capítulo 3, uma breve conceitualização é realizada a partir das principais arestas que são utilizadas para a construção do método de predição de genes deste projeto. No Capítulo 4, uma descrição sucinta é realizada para cada etapa metodológica do projeto. O Capítulo 5 apresenta os resultados obtidos a partir da aplicação do método proposto e uma discussão sobre o que foi encontrado. Finalmente, no capítulo 6 são relatas as considerações finais sobre o desenvolvimento e resultados do projeto, bem como as dificuldades encontradas e o direcionamento para trabalhos futuros. 


\section{Capítulo 2}

\section{Estado da Arte}

Neste capítulo descrevemos os resultados da pesquisa bibliográfica sobre alguns conceitos relacionados a doenças complexas e métodos comumente utilizados para a predição de genes candidatos destas doenças. Daremos ênfase àqueles que utilizam a integração de dados através de vocabulários controlados e ontologias.

\subsection{Doenças Complexas}

Doenças cardíacas, psiquiátricas, oncológicas: todas são doenças complexas ou multifatoriais, sendo que as mesmas não podem ser associadas exclusivamente a mutações em um único gene ou a um fator ambiental. Acredita-se que estas surjam a partir de vários fatores predisponentes, tanto genéticos como não genéticos (LESNICK et al., 2007).

As mutações gênicas isoladas, associadas às doenças complexas, apresentam pequenos sinais ou sintomas atribuíveis. Entretanto, a junção das ações de inúmeras mutações gênicas dentro de vias de interação pode desempenhar um papel importante na predisposição de doenças complexas. Descobertas que relacionem a ação de vários genes podem apresentar benefícios consideráveis à saúde pública, tanto em âmbito de prevenção quanto de tratamento. Essa dinâmica entre mutações gênicas nas vias de interação de genes apresenta efeitos pleiotrópicos em doenças complexas. A pleiotropia ocorre quando um gene apresenta um efeito em múltiplos fenótipos. Os mecanismos moleculares da pleiotropia podem ser divididos em múltiplas funções moleculares de um único gene e múltiplas consequências de uma única função molecular (SIVAKUMARAN et al., 2011).

Os efeitos fenotípicos que os genes sozinhos podem impor em vários sistemas muitas vezes nos dão uma visão sobre a função biológica de genes específicos. Genes pleiotrópicos também podem fornecer informações valiosas sobre a evolução de diferentes genes e famílias de genes. Por exemplo, como os genes são associados para novos fins, que vão além do que se acredita ser sua função original. Desta forma, a pleiotropia reflete o fato de que a maioria das 
proteínas têm vários papéis em tipos de células distintas. Assim, qualquer variação genética que altere a expressão ou a função do gene pode potencialmente ter efeitos de grande porte em uma grande variedade de tecidos ou orgãos (HODGKIN, 1998).

A pleiotropia pode ser visualizada também em doenças que são relacionadas, como por exemplo, Obesidade e Diabetes. Ambas as doenças são metabólicas e compartilham fatores genéticos entre suas causas, como mutações no gene ENPP1, que realiza a mediação de alguns efeitos do hormônio da insulina no metabolismo da glicose (MEYRE et al., 2005).

Enquanto pode ser lógico e comum categorizar doenças em classificações discretas, um aspecto importante das doenças complexas é que elas tendem a se sobrepor, de diversos modos, com doenças relacionadas. Dentro de cada classe de doenças, aquelas que estão relacionadas podem compartilhar características que se sobrepõem ou são similares. Esta sobreposição pode se manifestar através de características clínicas da doença, através de um espectro de sintomas de uma classificação de doença ou através de comorbidades de doenças e fenótipos relacionados a pacientes. Isto sugere que fatores etiológicos em uma dada doença podem ser compartilhados em doenças relacionadas (BECKER, 2004).

A Figura 2.1 ilustra como a pleiotropia de genes pode favorecer as múltiplas causas de doenças complexas. Nesta ilustração vemos que o Gene 1 está associado a duas doenças, A e B, enquanto o Gene 2 está associado às doenças B e C. Podemos observar a multiplicidade de causas de uma doença, como é o caso da doença B, que apresenta associações de dois genes diferentes. Além disso, podemos observar a multiplicidade de ações que um determinado gene pode ter em mais de uma doença.

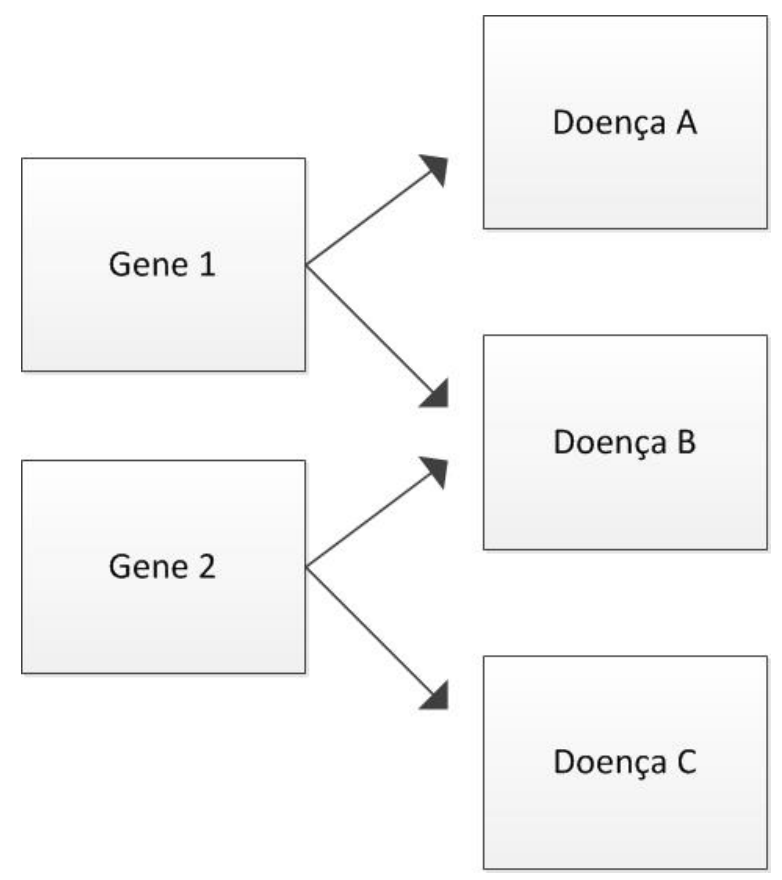

Figura 2.1: Efeito pleiotrópico de genes associados a causas de múltiplas doenças complexas.

A identificação de genes associados a essas doenças complexas é o objetivo de vários grupos de pesquisas da área da Bioinformática que buscam melhorar a medicina e o melhor 
entendimento de funções genéticas, interações e processos biológicos. Diversas abordagens computacionais com o objetivo de realizar a predição de genes candidatos são baseadas em anotações funcionais, dados de expressão gênica ou de recursos baseados no sequenciamento. A seguir, especificamos o escopo utilizado para a realização de alguns dos métodos conhecidos de predição de genes e o levantamento de algumas pesquisas e resultados que utilizaram os mesmos métodos para a realização da predição gênica.

\subsection{Métodos de Predição de Genes}

Os métodos de predição de genes são classificados de acordo com seu tipo e evidência. Os tipos possíveis para classificação de métodos de predição de genes são: Priorização e Seleção. $\mathrm{Na}$ Priorização, o objetivo dos métodos é de ranquear o gene associado à doença com o escore mais alto possível em uma lista de genes candidatos. Na Seleção, o objetivo é obter uma redução significativa do subconjunto de genes candidatos, mantendo uma probabilidade alta de selecionar o verdadeiro gene associado à doença entre eles (BROMBERG, 2013).

Os tipos de evidências utilizados dentre os métodos de predição de genes são variados. Existe uma diversidade de fontes de dados que podem ser utilizadas com sucesso para explorar a predição de genes candidatos associados a uma determinada doença (PIRO; CUNTO, 2012). Vejamos alguns destes métodos de evidência:

- Anotações funcionais: Esta evidência se baseia no fato de que um gene é candidato a ser associado a uma determinada doença, caso este seja membro de uma mesma via molecular, função, ou é acionado na mesma localização celular ou de tecidos de outros genes que já foram associados à mesma doença. Como existem diversas bases de dados de anotações destas propriedades de genes, é necessária a utilização de métodos computacionais para a realização desta integração de fontes de dados (BROMBERG, 2013).

O crescimento da utilização de arquiteturas distribuídas, especialmente no ambiente Web, contribuiu para que informações originalmente isoladas sejam disponibilizadas para o uso de maneira integrada. No campo da bioinformática, iniciativas da comunidade científica internacional levaram a um crescimento explosivo de informações biológicas geradas diariamente. A preocupação inicial era a criação e manutenção de bancos de dados para armazenar informação biológica. Conforme as bases de dados genômicas foram sendo preenchidas, e os genomas sequenciados, o foco das pesquisas começou a ser transferido. Ele passa do mapeamento dos genomas para a análise da vasta gama de informações resultantes da caracterização funcional dos genes através da Biologia Molecular e Bioinformática. Torna-se fundamental a integração entre os dados obtidos pelos diversos projetos de pesquisa ao redor do mundo sobre o interrelacionamento de enzimas, genes, componentes químicos, doenças, espécies, tipos de 
células e órgãos (MENDES; PN, 2005).

Ontologias assumem o papel desta integração, viabilizando a interoperabilidade semântica de sistemas distribuídos heterogeneamente. Ontologia é um conjunto de conceitos padronizados onde termos e definições devem ser aceitos por uma comunidade no âmbito de um domínio, e tem por finalidade permitir que múltiplos agentes compartilhem conhecimento. Uma ontologia consiste em termos, definições e axiomas relativos a eles. As ontologias constituem um meio poderoso de inter-relacionar sistemas. São elaboradas, principalmente, visando à estruturação de bases de conhecimento ou para serem utilizadas como ferramentas semânticas no suporte à interoperabilidade entre sistemas de informação (CAMPOS, 2010).

No âmbito da genética, a ontologia é utilizada para realizar a caracterização funcional dos genes, descrevendo seus domínios de vias de interação, vias metabólicas, regulatórias, localização celular, processos biológicos que seus produtos gênicos participam e suas respectivas funções celulares. Esta integração é realizada através de anotações de termos utilizando vocabulários controlados.

- Evidência Textual: Baseia-se na existência de uma coocorrência de termos anotados na literatura para o gene candidato e para a doença que está sendo analisada (PIRO; CUNTO, 2012). Este tipo de evidência, aliada com informações funcionais, constituem um dos métodos mais íntegros para a avaliação de genes candidatos. O problema é a escassez da unificação de vocabulários controlados de diferentes fontes de dados da literatura para a realização de mineração de texto automática. Uma das ferramentas capazes de realizar essa unificação de dados de diversas bases é o Sistema Unificado de Linguagem Médica (UMLS, do termo em inglês Unified Medical Language System) (UMLS, 2014). O Metatesauro da UMLS é um grande repositório, multiuso, e de múltiplos bancos de dados de terminologias que contém informações sobre conceitos biomédicos e de saúde. O mesmo representa conceitos biomédicos derivados de uma variedade de vocabulários controlados e classificações.

O projeto da UMLS procura superar duas barreiras importantes para o desenvolvimento de sistemas de informações. Estas barreiras são a disparidade de terminologias usadas em diferentes fontes de informação e a diversidade de tipos de usuários. O projeto pode ajudar profissionais da saúde a tomarem melhores decisões. É também uma fonte de conhecimento para desenvolvedores de sistemas, que pode ser usada para construção de aplicações para a recuperação e integração de informações biomédicas de diversas bases de dados (BODENREIDER, 2004).

- Espécies Cruzadas: Genes candidatos podem apresentar homólogos que implicam na geração de fenótipos similares de outras espécies. Dados de outras espécies também podem ser usados de forma complementar com outros métodos de predição para filtrar dados humanos. O objetivo é de reduzir o ruído e/ou mudar o foco para aspectos 
fundamentais que foram preservados no curso da evolução (BROMBERG, 2013).

- Relações Fenotípicas: Caso a doença que está sendo estudada não apresente um conjunto vasto de genes candidatos para realizar outras análises de evidências, a saída é a busca de doenças que apresentem fenótipos similares à doença em questão. Neste caso, tomar como referência genes de doenças similares ou relacionadas, pode ser apropriado para a predição de genes candidatos (HAN; MARC, 2004).

- Interações Proteína-Proteína: Estas interações são uma das mais fortes manifestações da relação funcional entre genes. As proteínas que se interagem, quando sofrem mutações podem levar ao mesmo fenótipo da doença. É claramente intuitivo que proteínas que interagem fisicamente irão realizar uma função comum com frequência. Desta forma, uma alteração deletéria de qualquer uma destas proteínas apresenta alta probabilidade de desenvolver fenótipos similares (OTI, 2006).

Diversos estudos combinaram diferentes métodos de evidência para a realização da predição de genes candidatos a doenças. (SUN et al., 2009) apresentaram uma abordagem em que os dados gênicos foram coletados de diversos tipos de bases de dados: estudos de associações, análises de relacionamentos, expressão gênica e buscas na literatura sobre Esquizofrenia. A partir da coleta dos genes, os mesmos receberam pontuações e pesos através de métodos de classificação. Posteriormente, os genes centrais dos métodos de pontuações anteriores foram novamente filtrados através do cálculo de $p$-valor em Estudos de Associações em Genômica Ampla (GWAS, do termo em inglês Genome-Wide Association Study). Através desses filtros, os genes foram finalmente selecionados e priorizados.

O estudo apresentado por (YU et al., 2010b) realiza a mineração de texto de diversas bases de dados (Gene Ontology, MeSH, eVOC, OMIM, LDDB, KO, MPO, SNOMED-CT e UniprotKB) para selecionar vocabulários controlados de genes relacionados a doenças através da priorização dos mesmos. Ele se utiliza de métodos estatísticos de classificação e treinamento.

Métodos propostos por (GUDIVADA et al., 2008) apresentam a possibilidade de utilização de técnicas e padrões da Semântica Web para a busca de genes relacionados a doenças. Ontologias podem ser utilizadas para integrar anotações genômicas e proteômicas ao conjunto de genes candidatos. Grafos são construídos a partir destas anotações de genes e uma análise de centralidade é aplicada para classificar elementos da rede. Esta análise de centralidade determina a importância relativa de um nó dentro da rede, medida calculada pelo número de ligações em direção a um nó e pelo número de ligações que sai de um nó em um grafo direcionado. Elementos centrais em redes biológicas são geralmente tratados como essenciais e podem ser relacionados a termos importantes que levam a genes candidatos fortes.

A quantidade de dados de relações fenotípicas e genotípicas disponíveis atualmente é 
enorme e isto levou à construção do diseasoma, que é definido por um grafo bipartido constituído de dois conjuntos de nós disjuntos. Um conjunto de nós corresponde a todas as doenças geneticamente conhecidas, enquanto que o outro conjunto corresponde a todos os genes associados a doenças do genoma humano. Uma doença e um gene são conectados se mutações neste gene implicam nesta doença. Essas listas de doenças, genes e suas associações foram coletadas do OMIM, a base de dados que representa o mais completo e atual repositório de genes associados a doenças (GOH; CUSICK, 2007).

Através do diseasoma pode-se construir a rede de genes de doenças humanas, uma rede em que os genes são conectados caso compartilhem implicação em uma mesma doença.

Como discussão importante desta rede resultante, foi constatada a alta heterogeneidade em relação a genes e doenças. Enquanto muitas doenças associadas apresentavam poucos genes, algumas como a surdez, leucemia e câncer de colón são associadas a mais de 30 genes. Ou seja, enquanto muitos genes estão envolvidos em poucas doenças, alguns genes estão envolvidos em mais de 10 doenças, transformando-se em hubs na rede. Isto confirma a teoria da pleiotropia dos genes, como citado no começo deste capítulo (GOH; CHOI, 2012).

Outro ponto de discussão dessa rede é que embora a mesma apresente uma conectividade intensa, as conexões entre as doenças não são aleatórias. Ao contrário, doenças tendem a formar agrupamentos por patofisiologia similar. A descoberta destas ligações entre as doenças não somente nos ajuda a entender como fenótipos diferentes, muitas vezes abordados por diferentes categorias médicas, estão ligados em nível molecular, mas também nos auxilia a compreender porque certos grupos de doenças se manifestam juntos. As comorbidades que são mostradas a partir do diseasoma oferecem visões de novas abordagens para a predição de genes candidatos associados a estas comorbidades. Os resultados destas abordagens podem produzir novas técnicas de prevenção de doenças, diagnósticos e tratamentos.

\subsection{Considerações}

Através desses conceitos sobre doenças complexas, métodos de predição de genes candidatos e a grande contribuição feita pela construção do diseasoma, foi possível realizar um processo metodológico de pesquisa. Este processo se concentra na predição de genes através do estudo epidemiológico de comorbidades de dados de internações hospitalares públicas do Brasil, assim como através de buscas de vocabulários controlados de integração de dados e ontologias. 


\section{Capítulo 3}

\section{Conceitualização}

Neste capítulo iremos abranger Ontologias e as ferramentas que foram utilizadas para a integração de dados epidemiológicos e genéticos e como as mesmas apresentam sua organização funcional.

\subsection{Proposta de Método para Predição de Genes}

A proposta deste projeto parte da utilização de informações de associações de doenças através das comorbidades coletadas e pela coleta dos genes responsáveis por cada uma destas doenças. Realiza-se então a inter-relação destes genes, a fim de expandir as listas de genes candidatos de cada doença.

A Figura 3.1 ilustra o fluxo básico para a realização do método de predição de genes através das informações contidas em comorbidades e suas respectivas relações gênicas.

Temos dois desafios a serem solucionados através deste projeto. O primeiro deles é a construção de um método capaz de, a partir de um par de doenças codificadas pelo sistema CID-10, realizar a coleta dos genes causadores dessas doenças. O segundo desafio é o de realizar a inter-relação dos conjuntos de genes causadores de duas doenças, através de anotações funcionais, capazes de expandir as listas de genes candidatos de cada doença que está sendo estudada.

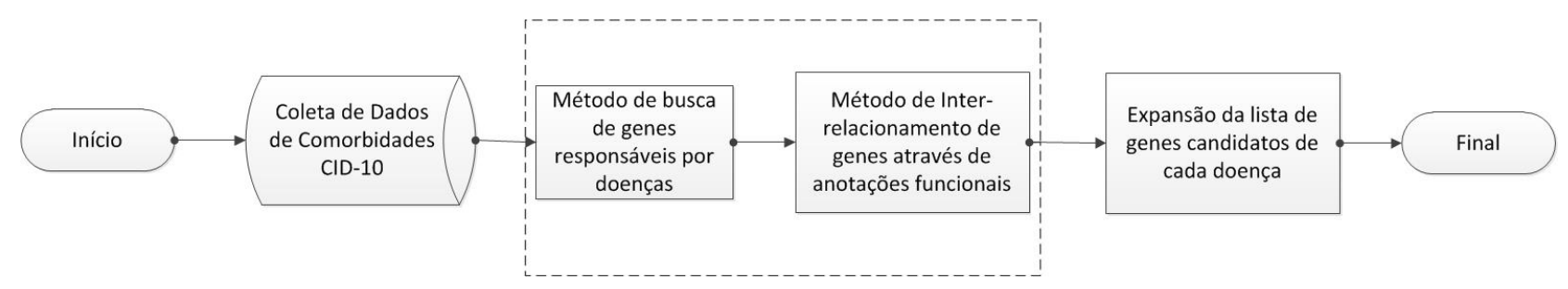

Figura 3.1: Fluxo básico do método a ser proposto.

A seguir, iremos definir alguns conceitos que são essenciais para a construção deste pro- 
jeto, focando a resolução desses dois desafios. Vamos nos concentrar no estudo do sistema da UMLS, que apresenta o objetivo de integração de fontes de vocabulários biomédicos. Além disso, iremos definir alguns conceitos referentes ao projeto Gene Ontology, capaz da integração de informações funcionais dos genes. Também iremos discutir os cálculos capazes de realizar a comparação e inter-relacionamento entre esses genes, através da Similaridade Semântica.

\subsection{Coleta de Genes}

Como citado anteriormente, as doenças registradas nas AIHs através dos campos de diagnóstico principal e secundário apresentam codificação específica do CID-10. Desta forma, o método que será proposto deverá levar em consideração a coleta de genes através da codificação dessas doenças.

A coleta de genes é baseada em uma busca na literatura de artigos e materiais científicos publicados que comprovaram ou evidenciaram chances de determinados genes estarem associados de forma causal a uma doença específica. Tal busca de genes pode ser realizada através do projeto Online Mendelian Inheritance In Man (OMIM).

O projeto OMIM é uma base de dados que possui informações de muitas doenças que apresentam fatores genéticos como uma de suas causas. O ínicio do projeto OMIM focava somente doenças mendelianas, ou seja, doenças geneticamente monofatoriais. Porém, com o aparecimento de estudos de doenças complexas, o OMIM passou a apresentar mapeamentos de mais de 3000 doenças complexas e seus genes responsáveis. O principal foco do projeto OMIM é a identificação do relacionamento do fenótipo e genótipo.

Entretanto, o OMIM possui uma classificação particular de suas doenças. O OMIM é uma base de dados não estruturada, escrita em texto livre, em que os nomes das doenças não são os mesmos nomes utilizados no CID-10. Não podemos realizar uma busca textual usando os codigos ou identificadores do CID-10 nesta base de dados. Sendo assim, temos que utilizar um mapeamento intermediário para realizarmos a coleta de genes para cada um dos códigos de doenças das internações hospitalares (ROQUE et al., 2011).

Para tanto, iremos utilizar o Sistema Unificado de Linguagem Médica (UMLS) para realizar um mapeamento intermediário dos códigos do CID-10 e os nomes de doenças que compõem o OMIM.

\subsubsection{UMLS}

Conforme descrito na Seção 2.2, a UMLS tem como objetivo a unificação de terminologias de diversas fontes de dados biomédicos. 
O Metatesauro da UMLS transcende suas mais de 150 fontes individuais, organizando a coleção resultante por significado e adicionando informações úteis e relações interconceituais não presentes em qualquer uma de suas fontes (bases) de vocabulário. São exemplos de bases de vocabulários relacionadas à biomedicina: OMIM, MESH, CID-10 e Snomed. O objetivo principal da construção do Metatesauro é de compreender o significado pretendido de cada termo em cada base de terminologias e de conectar todos os termos que apresentam o mesmo significado (SCHUYLER et al., 1993).

A noção de conceito, que vai além de um termo é o propósito do Metatesauro da UMLS. Por meio da ligação de diferentes termos usados para expressar o mesmo conceito, ele transcende vocabulários específicos, significados convencionais e reduz a ambiguidade.

O conjunto completo de termos preferidos, variantes léxicas e sinônimos forma um conceito ou um grupo conceitual. Quanto maior for este conjunto, maior será a oportunidade para reconhecimento, interpretação e entendimento do conceito. As seções seguintes nos mostra como é a organização estrutural que a UMLS utiliza para realizar a unificação de termos de diversas fontes em um único conceito (Manual-UMLS, 2014).

\subsubsection{Conceitos e Identificadores de Conceitos (CUIs)}

Um conceito representa um significado, sendo que um significado pode ser representado por diferentes termos.

Cada conceito no Metatesauro apresenta um identificador de conceito único e permanente (CUI). O CUI não apresenta um significado intrínseco. Em outras palavras, não se pode inferir nada sobre o conceito apenas olhando o CUI. Em princípio, o identificador para um conceito nunca muda.

\subsubsection{Termos e Identificadores de Termos (SUIs)}

Cada variante de termo em cada linguagem no Metatesauro apresenta um identificador de termo (SUI). Qualquer variação de caracteres, pontuação, abreviação ou numeração apresenta um SUI diferente. O mesmo nome em diferentes línguas (por exemplo, em português e espanhol) apresenta identificadores de termo diferentes. Se um mesmo termo apresenta mais de um siginificado, o mesmo será ligado a mais de um identificador de conceito (CUI).

\subsubsection{Atómos e Identificadores de Átomos (AUIs)}

Os blocos básicos de construção ou átomos que são construídos pelo Metatesauro são os termos de conceitos de cada fonte de vocabulário. Todas as ocorrências de um termo em cada fonte de vocabulário são atribuídas a um identificador único de átomo (AUI). Quando o mesmo termo aparece em múltiplas fontes de vocabulários, haverá um AUI para todas as 
ocorrências deste termo. Todos esses AUIs são ligados a um SUI, desde que eles representem ocorrências de um mesmo termo. Diferentemente dos identificadores de termos (SUI), um AUI sempre estará ligado a um único identificador de conceito (CUI), pois cada ocorrência de um termo em uma fonte de vocabulário poderá ser representada por somente um significado.

Tabela 3.1: Categorização de Terminologias UMLS.

\begin{tabular}{lll}
\hline Conceito (CUI) & Termos (SUI) & Átomos (AUIs) \\
\hline C0004238 & S0016668 & A11928858 \\
Fibrilação & Fibrilação & Fibrilação \\
Atrial & Atrial & Atrial \\
& & (OMIM) \\
& & A169833191 \\
& & Fibrilação \\
& & Atrial \\
& & (CID-9) \\
\hline C0004238 & S0016669 & A0027668 \\
Fibrilações & Fibrilações & Fibrilações \\
Atrial & Atrial & Atrial \\
& & (MESH) \\
\hline C0004238 & S0016899 & A0027930 \\
Fibrilação & Fibrilação & Fibrilação \\
Auricular & Auricular & Auricular \\
& & (PSY) \\
\hline C0004238 & S0016900 & A0027932 \\
Fibrilações & Fibrilações & Fibrilações \\
Auricular & Auricular & Auricular \\
& & (MESH) \\
\hline
\end{tabular}

Como mostrado na Tabela 3.1, o termo "Fibrilação Atrial"aparece como um átomo para mais de uma fonte de vocabulário e apresenta um AUI distinto para cada ocorrência. Desde que esses átomos apresentem termos ou conceitos idênticos, eles são ligados a um mesmo SUI. Como "Fibrilação Atrial"e "Fibrilação Auricular"foram considerados por apresentarem o mesmo significado, eles são ligados a um mesmo CUI.

Todos esses identificadores fornecem propósitos importantes na construção do Metatesauro e permitem uma customização eficiente e acurada para os objetivos específicos.

\subsubsection{Relacionamentos}

O Metatesauro inclui muitos relacionamentos entre diferentes conceitos. Muitas destas relações vêm de fontes de vocabulários individuais. Os relacionamentos são expressos em termos de CUIs e AUIs. O Metatesauro contém relacionamentos não sinônimos entre conceitos de uma mesma fonte de vocabulário e entre conceitos de diferentes vocabulários. O mesmo inclui todos os relacionamentos presentes em suas fontes e alguns adicionais que foram fei- 
tos para conectar conceitos relacionados. Em geral, os relacionamentos que são atribuídos por fontes de vocabulários conectam conceitos relacionados próximos, assim como aqueles que compartilham propriedades comuns ou são relacionados por definição. Por exemplo, um membro de uma classe de drogas como a penicilina será conectado ao nome de sua classe, antibióticos; uma infecção bacteriana será conectada à bactéria que a causa. A seguir, listamos as definições e atribuições dos dois tipos de relacionamentos existentes na UMLS, sendo que ambos serão utilizados para realizar o mapeamento de códigos de doenças CID-10 para doenças e genes da base OMIM.

Relacionamentos de uma mesma Fonte de Vocabulário A maioria dos relacionamentos de uma mesma fonte é atribuída pelas fontes de vocabulários individuais. Esses relacionamentos ocorrem através de combinações hierárquicas ou contextos explícitos ou implícitos em uma fonte de vocabulário, estruturas de referência cruzada, regras para aplicação de qualificadores ou conexões entre diferentes tipos de nomes para o mesmo conceito.

Algumas das relações entre uma mesma fonte de vocabulário são relações estatísticas, que são computadas pela determinação da frequência em que cada conceito em um vocabulário específico coocorre em registros da base de dados. Por exemplo, existem relações de coocorrência para o número de vezes que os conceitos tem coocorrido como tópicos chave de um mesmo artigo na base da MEDLINE. Em contraste com os relacionamentos atribuídos em fontes de vocabulários, as relações estatísticas no Metatesauro podem conectar diferentes conceitos, como doenças e genes.

Relacionamentos entre Fontes de Vocabulário $O$ relacionamento entre fontes primárias no Metatesauro são os relacionamentos de sinônimos representados na estrutura de conceito do Metatesauro. O mesmo também inclui algumas relações não sinônimas de diferentes fontes de vocabulários. Esses relacionamentos são essenciais para os profissionais que necessitam de um mapeamento de conceitos entre fontes de vocabulários diferentes.

É através desses relacionamentos entre termos e conceitos que iremos construir um método capaz de, a partir da entrada de um código de doença CID-10, coletar os termos OMIM referentes ao mesmo conceito do código da doença para posteriormente realizar a coleta de genes.

A Figura 3.2 ilustra esse mapeamento de códigos CID-10 em OMIM através da UMLS.

Após a coleta dos genes para cada doença que forma o par de comorbidade, o objetivo final do projeto é de inter-relacionar os genes que compõem os diferentes conjuntos de genes relacionados a cada doença do par de comorbidade. Assim sendo, iremos expandir nossas listas de genes candidatos, para então realizarmos validações de acordo com as possíveis evidências descritas na Seção 2.2 .

O inter-relacionamento de genes será realizado através da comparação de similaridade 


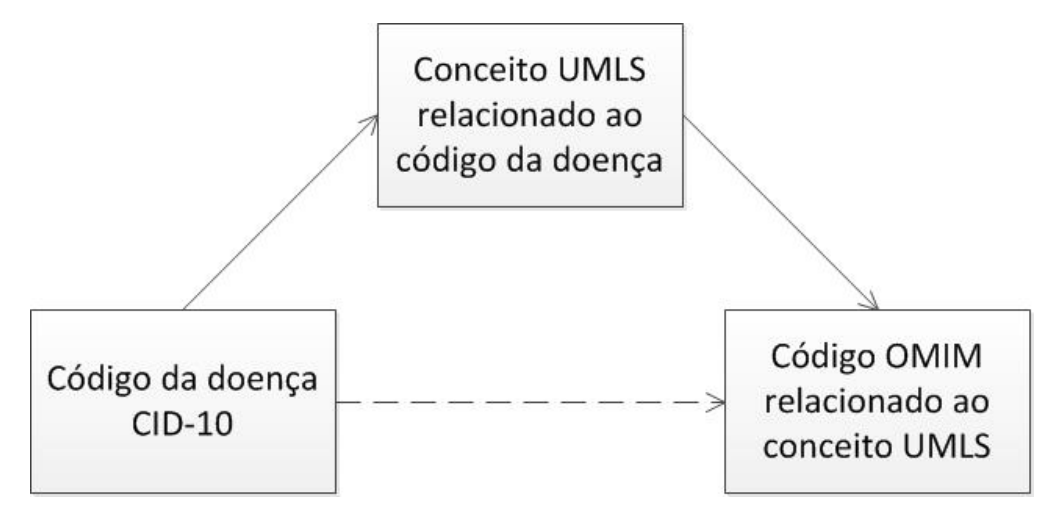

Figura 3.2: Mapeamento de códigos CID-10 em OMIM através dos conceitos referentes da UMLS.

de termos anotados para cada um dos genes, utilizando Ontologias. A seguir, introduzimos conceitos da Ontologia gênica mais conhecida entre a comunidade científica, o Gene Ontology.

\subsection{Gene Ontology}

O projeto do Gene Ontology (GO) apresenta um esforço colaborativo para tratar da necessidade de descrições consistentes e únicas de produtos gênicos. O projeto começou em 1998 com a colaboração entre três bancos de dados de modelos de organismos, FlyBase (de Drosophilas), o Banco de dados do Genoma de Saccharomyces (SGD) e o Banco de genoma de Ratos (MGD). O objetivo do projeto é de produzir um vocabulário controlado, comum, estruturado e precisamente definido para a descrição de todos os genes e seus produtos gênicos em um organismo (ASHBURNER et al., 2000).

O projeto GO desenvolveu três estruturas controladas de vocabulários (ontologias) que descrevem o produto de genes em termos dos processos biológicos associados, componentes celulares e funções moleculares de espécies dependentes. Existem três aspectos diferentes para essa aplicação: primeiro, o desenvolvimento e manutenção das próprias ontologias; segundo, a anotação dos produtos gênicos, que realiza as associações entre as ontologias e os genes e os produtos gênicos dentro dos bancos de dados colaborativos; e em terceiro, o desenvolvimento de ferramentas para facilitar a criação, manutenção e o uso de ontologias.

O uso dos termos de GO dos bancos de dados facilita pesquisas uniformes ao redor deles. A estrutura fornecida pelo GO permite aos anotadores atribuir propriedades aos genes ou aos produtos gênicos em diferentes níveis, dependendo da profundidade de conhecimento sobre a entidade.

A ontologia GO é estruturada como um grafo acíclico direcionado e cada termo define relações de um ou mais termos do mesmo domínio, e às vezes a outros domínios. $\mathrm{O}$ vocabulário GO é projetado para ser neutro em relação às espécies e inclui termos aplicados a procariotos e eucariotos, organismos uni e multicelulares (LEWIS, 2005). 
O projeto GO fornece uma ontologia de termos definidos que representam as propriedades dos produtos gênicos. A ontologia cobre três domínios nos quais os termos podem ser associados a:

- Processo Biológico: Operações ou grupos de eventos moleculares com começo e fim definidos, pertinente ao funcionamento de unidades vivas integradas: células, tecidos, órgãos e organismos. É uma serie de eventos realizados por um ou mais conjuntos ordenados de funções moleculares. Exemplos de termos de processos biológicos são "processo fisiológico celular"ou "transdução de sinal". Pode ser difícil distinguir um processo biológico de uma função molecular, porém a regra geral é que um processo deve ter mais que um passo distinto. Todo processo deve ter um começo e um fim, e estes devem ser claramente estabelecidos na definição do termo. A ontologia do processo biológico inclui termos que representam coleções de processos assim como termos que representam um processo específico.

- Componente Celular: A parte da célula ou seu ambiente extracelular, podendo ser uma estrutura anatômica (como um retículo endoplasmático ou um núcleo) ou um grupo de produto gênico (ribossomo, proteossomo ou um dímero proteico). Geralmente, um produto proteico está localizado em ou é um subcomponente de um componente celular particular. A ontologia do componente celular representa relações "é_um"completas, isto é, todos os termos tem um caminho à raiz que passa unicamente através de relações "é_um".

- Função Molecular: Descreve atividades, assim como atividades catalíticas e de ligação, que ocorrem em nível molecular. Os termos de função molecular representam atividades ao invés de entidades (moléculas ou complexos) que realizam as ações. Não representam especificamente quando ou onde, ou em qual contexto, a ação ocorre. Funções moleculares normalmente correspondem a atividades que podem ser realizadas por produtos gênicos individuais.

O GO fornece um esquema de representação da função do produto gênico em um contexto celular. A Figura 3.3 mostra como o GO é estruturado como uma árvore independente de grafos acíclicos direcionados que correspondem às categorias ortogonais dos produtos gênicos: função molecular, processo biológico e componente celular, domínios que foram definidos anteriormente.

Os nós no grafo representam termos que descrevem componentes de uma função do produto gênico. O GO liga cada um dos termos por seus relacionamentos, comumente dos tipos "é_um" e "parte_de". 


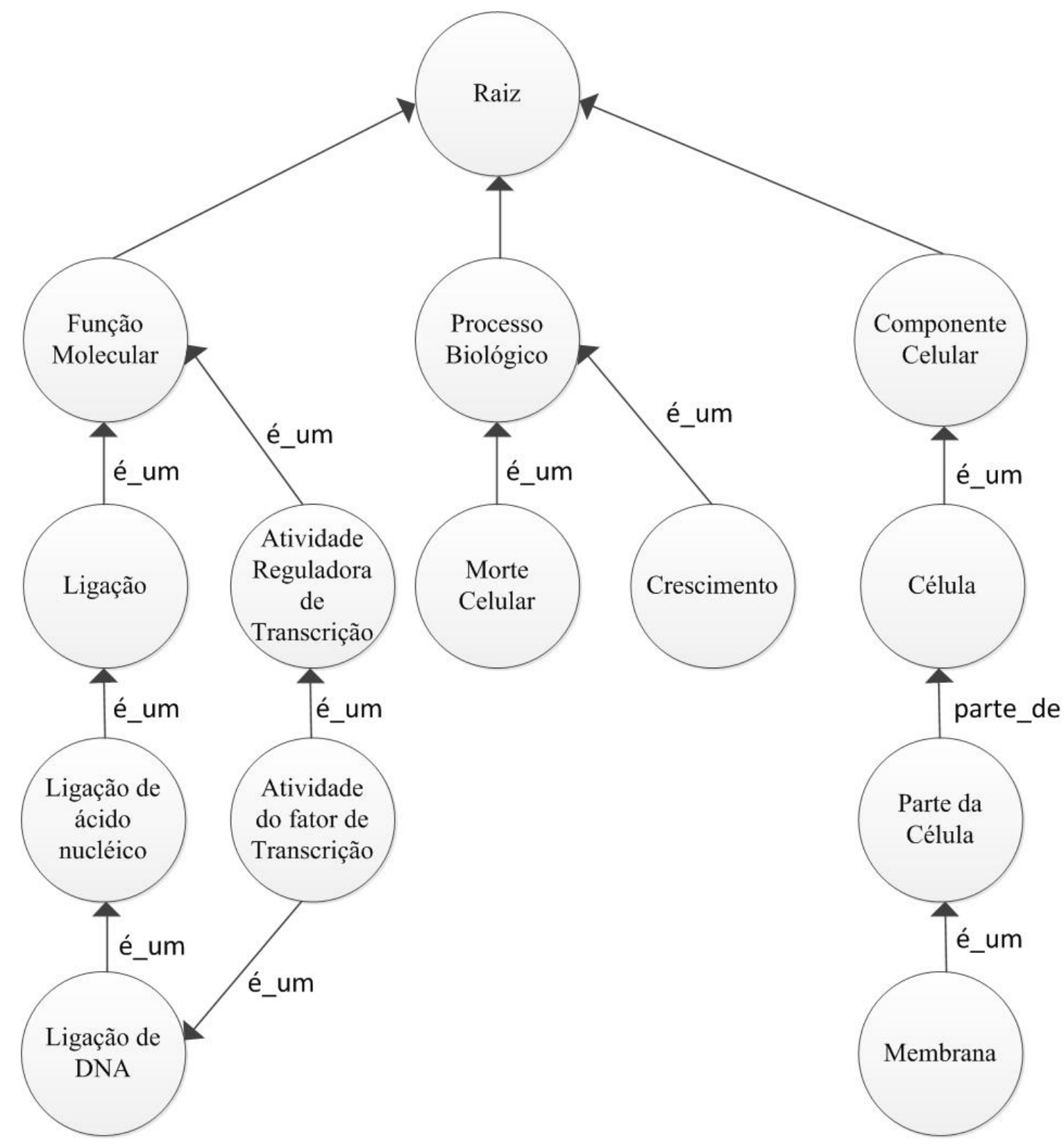

Figura 3.3: Organização relacional do GO.

\subsubsection{Comparação entre Genes}

Comparação e classificação têm sido pilares centrais da biologia. Como todo o conhecimento científico, as leis e modelos da biologia são derivados da comparação de entidades (como genes, células, organismos, populações, espécies) e da busca de suas similaridades e diferenças (PESQUITA et al., 2009).

Entretanto, a biologia é diferente de outras ciências em que o conhecimento pode ser reduzido em uma fórmula matemática. Assim, biólogos anotam seus conhecimentos através da linguagem natural como a dos artigos científicos, ou eles procuram outras formas de representação para organizar, como os esquemas de classificação. Quando novas entidades nascem, biólogos as abordam, comparando-as através de entidades conhecidas e realizando 
inferências de acordo com seus graus de similaridade.

A comparação de entidades biológicas nem sempre é trivial. Por exemplo, enquanto sequências ou estruturas de dois produtos gênicos podem ser comparadas diretamente através de algoritmos de alinhamento, o mesmo não é verdadeiro para seus aspectos funcionais. A diferença é a de que sequências e estruturas têm uma representação objetiva e propriedades mensuráveis, enquanto aspectos funcionais não têm. Isto não significa que é impossível comparar aspectos funcionais, mas para serem comparados eles devem ser expressos de forma comum e objetiva.

A adoção de ontologias para anotações biológicas fornece modos para comparação de entidades que de outra forma não seriam comparáveis. Por exemplo, se dois produtos gênicos são anotados em um mesmo esquema, nós podemos realizar uma comparação a partir dos termos em que os mesmos foram anotados. Enquanto esta comparação é frequentemente feita de maneira implícita, é possível realizar outras formas de comparação, como por exemplo, utilizando uma medida de Similaridade Semântica.

As comparações usando Similaridade Semântica tem um foco principal no GO, não somente porque é a ontologia mais usada na comunidade científica, mas também porque a comparação de produtos gênicos em um nível funcional é crucial para uma variedade de aplicações. Algumas destas aplicações: predição de interações de proteína, validação de predição de função, predição de localização celular e validação da anotação automática. No nosso caso de estudo, estas medidas de Similaridade Semântica irão mensurar o quanto os genes relacionados são similares e compartilham associações com o par morbidade-comorbidade.

A seguir, listamos as classificações de medidas de Similaridade Semântica disponíveis atualmente e quais são mais apropriadas para o estudo de associações gênicas (PESQUITA et al., 2009). Somente as ontologias que estão estruturadas em forma de grafo possibilitam a realização dos cálculos de medidas de Similaridade Semântica descritas a seguir.

\subsubsection{Classificação de medidas de Similaridade Semântica}

Diversas abordagens estão disponíveis para quantificar a Similaridade Semântica entre termos ou entidades anotadas em uma ontologia representados por um grafo acíclico direcionado como o GO.

Medidas baseadas em arestas Abordagens baseadas em arestas estão fundamentadas principalmente na contagem de números de arestas no grafo entre dois termos anotados na ontologia em questão. A técnica mais comum, chamada de distância, seleciona o menor caminho ou a média de todos os caminhos, quando mais de um caminho existe. Esta técnica produz uma medida de distância entre dois termos, que pode ser facilmente convertida em uma medida de similaridade. Alternativamente, a técnica do caminho comum calcula a 
similaridade diretamente pelo comprimento do caminho do menor ancestral comum entre dois termos até a raiz.

Apesar destas abordagens serem intuitivas, elas estão baseadas em 2 assunções que normalmente são verdadeiras em ontologias biológicas: nós e arestas estão uniformemente distribuídos e níveis de arestas em ontologias correspondem à mesma distância semântica entre termos. Algumas estratégias foram propostas para atenuar estes dois pontos, como atribuir pesos às arestas de acordo com sua profundidade hierárquica. Entretanto, termos de uma mesma profundidade não necessariamente representam a mesma distância semântica, portanto estes pontos não podem ser resolvidos com esta estratégia.

Medidas baseadas em nós Abordagens baseadas em nós contam com a comparação das propriedades dos termos envolvidos, que podem ser relacionados aos próprios termos, seus ancestrais e seus descendentes. Um conceito comumente usado nestas abordagens é o conteúdo informacional ( $I C$ ), que mostra quanto um termo é especifico e informativo. O IC de um termo $c$ pode ser quantificado pelo logaritmo da probabilidade de ocorrência deste termo $c$ em um corpus específico, normalmente estimado pela sua frequência de anotação (WU; RUIZ, 2012).

$$
I C=-\log p(c)
$$

O conceito de $I C$ pode ser aplicado para os ancestrais comuns que dois termos apresentam para quantificar a informação que eles compartilham. Neste caso, o cálculo de Similaridade Semântica leva em conta o $I C$ dos termos que estão sendo comparados.

Abordagens baseadas em $I C$ são menos sensíveis aos problemas de distância semântica variável como são as medidas baseadas em arestas. Isto ocorre porque o $I C$ dá uma medida de especificidade do termo que é independente da sua profundidade na ontologia (a especificidade de um termo é dependente de seus filhos, mas não de seus pais). Entretanto, o $I C$ é viesado pelas tendências atuais nas pesquisas biomédicas, pois espera-se que termos relacionados às áreas de interesse cientificas tenham maior frequência de anotação de outros termos. Apesar disso, o uso de um $I C$ continua a fazer mais sentido dentro de uma visão probabilística: é mais provável que dois produtos gênicos compartilhem um termo comumente usado do que um termo comumente não usado.

Neste projeto iremos utilizar medidas baseadas em arestas para calcularmos a Similaridade Semântica dos conjuntos de termos anotados aos genes das doenças em estudo.

Existem diversas medidas de Similaridade Semântica baseadas em arestas.

(RESNIK, 1995) utiliza o conceito chamado de mica (most informative common ancestor), ou seja, o termo ontológico ancestral comum a dois termos que possui o maior conteúdo informacional. A similaridade entre dois termos é encontrada através da seguinte: 


$$
\operatorname{SimTermos}\left(c_{1}, c_{2}\right)=I C(\text { mica })
$$

A segunda abordagem para cálculo de Similaridade Semântica, a abordagem de (LIN, 1998), é um pouco mais elaborada e pode ser encontrada através da seguinte fórmula:

$$
\operatorname{Lin}\left(c_{1}, c_{2}\right)=2 * \operatorname{IC}(\text { mica }) / \operatorname{IC}\left(c_{1}\right)+\operatorname{IC}\left(c_{2}\right)
$$

A varíavel mica, como já foi descrita, representa o termo ancestral mais informativo entre $c_{1}$ e $c_{2}$. Já o $I C\left(c_{1}\right)$ e $I C\left(c_{2}\right)$ representam respectivamente o conteúdo informacional dos termos $c_{1}$ e $c_{2}$.

Um problema quando se aplicam estas medidas para produtos gênicos é que elas são usadas para a comparação de termos isolados, porém produtos gênicos apresentam muitos termos (PESQUITA et al., 2008). Deste modo, deve-se realizar a combinação desses cálculos para os conjuntos de termos anotados para cada gene, a partir da fórmula:

$$
\operatorname{SimGenes}\left(g_{1}, g_{2}\right)=\operatorname{MAX}\left(\operatorname{SimTermos}\left(t_{1}, t_{2}\right)\right)
$$

Tem-se que $g_{1}$ e $g_{2}$ são os genes que estão sendo comparados ao calcularmos a similaridade, e $t_{1}$ e $t_{2}$ correspondem ao conjunto de termos da GO anotados para $g_{1}$ e $g_{2}$ respectivamente. Ou seja, a similaridade de dois genes é dada pelo máximo mica entre os termos de cada gene. Deve-se notar que $g_{1}$ é o gene relacionado a uma doença e $g_{2}$ é o gene relacionado à outra doença que compartilham par morbidade-comorbidade nos registros hospitalares.

Aplicação das Medidas baseadas em arestas Como exemplificação da aplicação das medidas de Similaridade Semântica baseadas em arestas, podemos considerar a árvore de termos da Figura 3.4. A árvore mostra a distribuição de termos anotados em um determinado corpus e suas probabilidades de ocorrência neste corpus. Através das probabilidades de cada termo, podemos calcular o IC de cada um deles pela Fórmula 3.1.

Analisando os valores de probabilidades e $I C$, percebemos que enquanto a probabilidade de ocorrência aumenta, a informatividade diminui, então quanto mais abstrato for um conceito, menor será o conteúdo informacional deste. Além disso, caso o corpus de estudo apresentar somente um único conceito raiz anotado no GO, o IC dele será sempre 0.

Caso compararmos os termos "Receptor Transmembrana"e "Fotoreceptor", os ancestrais comuns destes são "Receptor", "Transdução de Sinal"e "Função Molecular". Analisando a Figura 3.4, podemos perceber que o ancestral comum com maior Conteúdo Informacional (mica) é o termo "Transdução de Sinal", com $I C=0,90$.

Assim, o valor de Similaridade Semântica de Resnik é de 0,90, pois este é calculado pelo $I C$ de mica, como mostrado através da Fórmula 3.2. 
Já para o valor de Similaridade Semântica de Lin para os mesmos termos, podemos afirmar que o valor é de 0,41, como mostrado através da Fórmula 3.3.

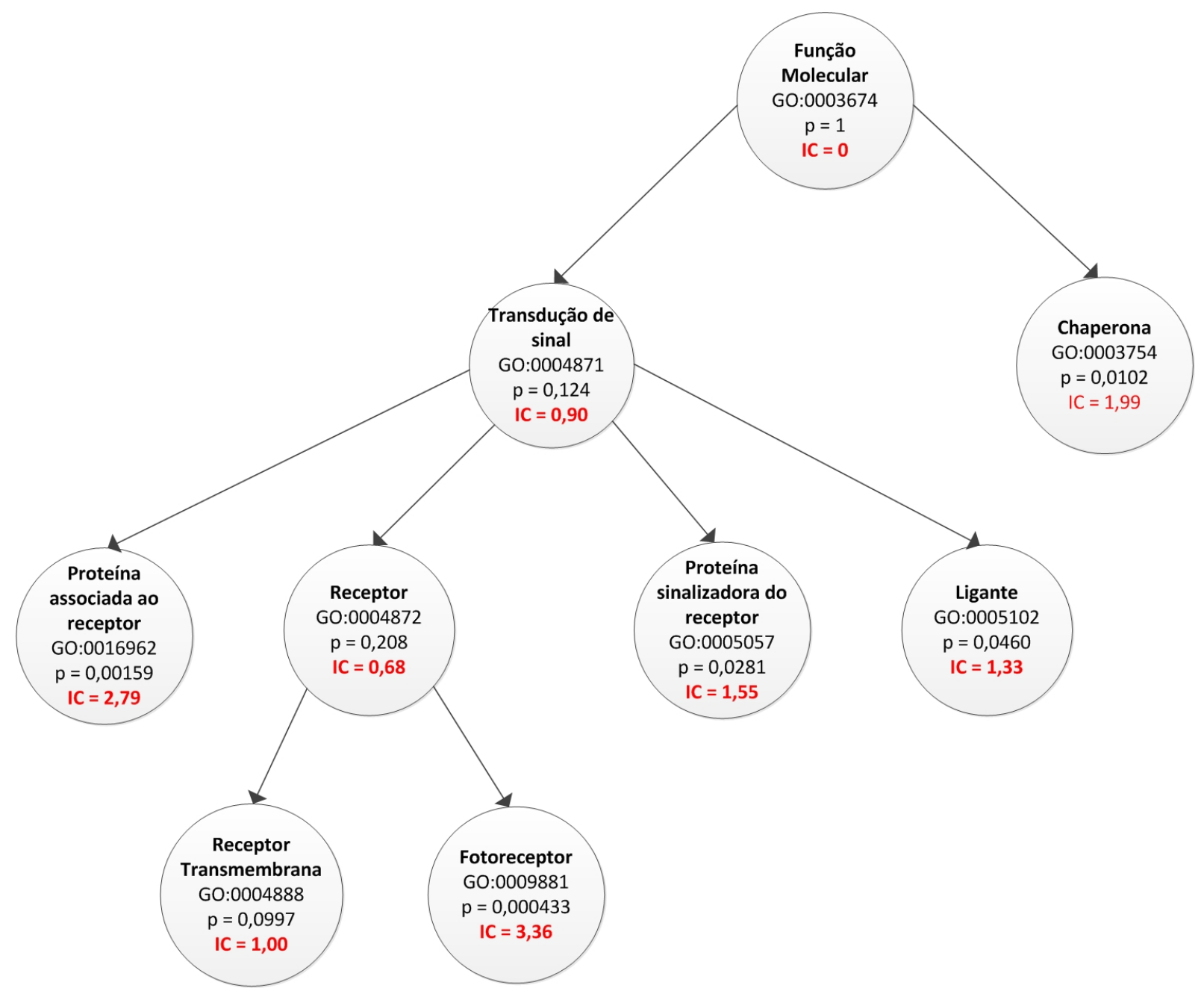

Figura 3.4: Exemplo de probabilidades e IC de termos do Gene Ontology.

\subsection{Considerações}

Por meio do estudo dessas ferramentas, capazes de utilizar vocabulários controlados para realizar integrações de diferentes fontes de dados biomédicos e realizar comparações de anotações gênicas, é que foi possível construir o processo metodólogico deste projeto. Este processo é capaz de integrar os dados de doenças que formam pares de comorbidades, coletar genes responsáveis por tais doenças e realizar comparações entre estes genes.

O resultado esperado de toda esta proposta é o de demonstrarmos que o estudo de comorbidades e suas relações gênicas pode nos auxiliar no âmbito de predição de genes. 


\section{Capítulo 4}

\section{Método para Predição de Genes}

Neste capítulo são apresentados os métodos da pesquisa adotada, considerando-se:

- a coleta de evidências em base de dados hospitalar;

- o método de filtragem dos registros de internação;

- o mapeamento de genes para cada classificação de doenças;

- o método para relacionamento desses genes, através da Similaridade Semântica de termos da ontologia anotados para os mesmos.

\subsection{Pipeline--Etapas do Projeto}

A Figura 4.1 ilustra as etapas que foram realizadas para a execução deste projeto. A seguir apresentamos uma descrição sucinta destas etapas.

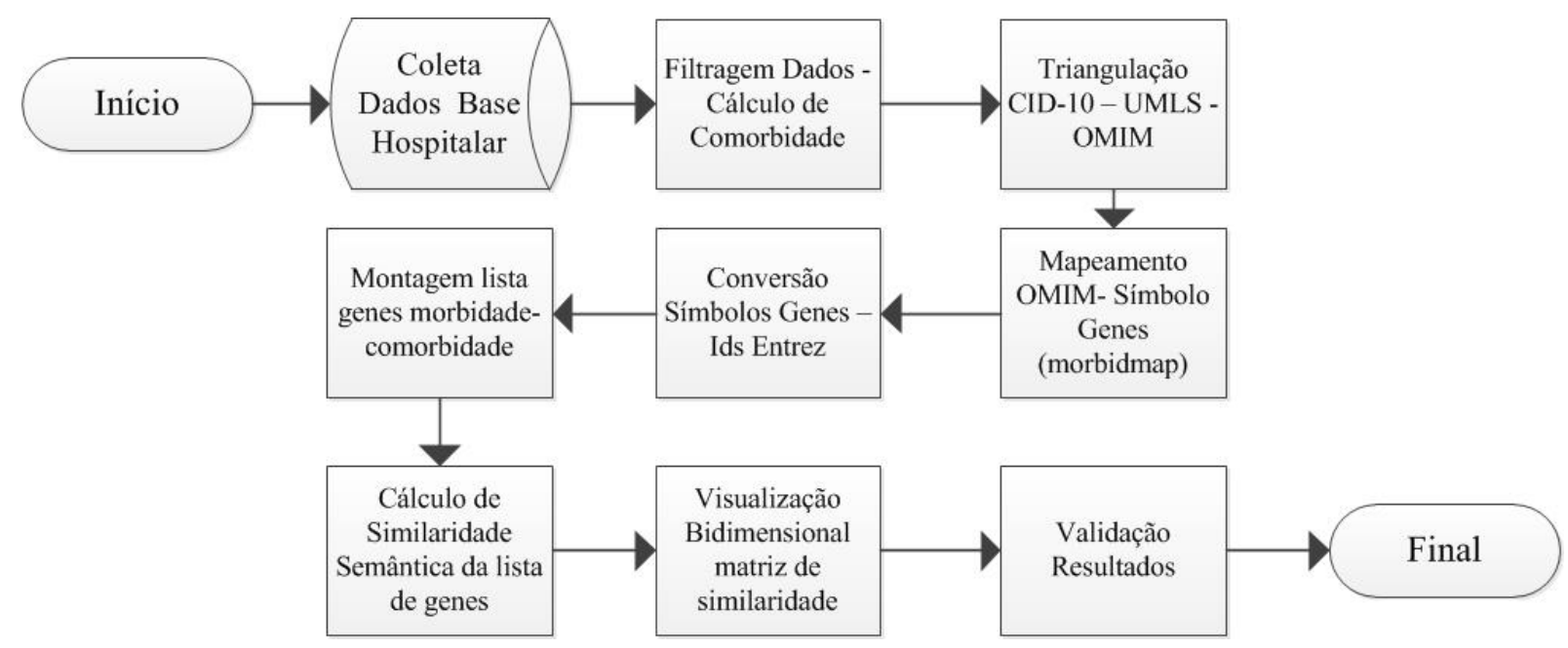

Figura 4.1: Pipeline de execução das etapas do projeto. 


\subsection{Coleta de Dados-Base Hospitalar}

Para a análise e coleta de dados sobre comorbidades foi utilizado o Sistema de Internações Hospitalares (SIH) do Datasus (DATASUS, 2014). O SIH do Sistema Único de Saúde (SUS) foi criado em 1990 pelo Ministério da Saúde, contendo informações que viabilizam efetuar o pagamento dos serviços hospitalares. Ele está estruturado na lógica da avaliação e controle da produção. Esses documentos são exigidos para o reembolso dos serviços hospitalares prestados pelos hospitais públicos e particulares vinculados ao SUS.

Este sistema contém informações sobre aproximadamente 15 milhões de internações/ano, sendo uma fonte de dados extremamente relevante para a programação, gerência e avaliação dos serviços hospitalares, além de ser de grande utilidade para a área de investigação em serviços de saúde, para estudos epidemiológicos e atividades de vigilância em saúde (VERAS; MARTINS, 1994).

As Autorizações de Internação Hospitalar (AIHs), documentos exigidos para controle do SIH, incluem como principais dados: informações de internações realizadas, valor dos procedimentos realizados, datas de entrada e saída do paciente, como também diagnósticos principal e secundário com seus respectivos CID-10. O Apêndice A ilustra um modelo de laudo utilizado para a emissão das AIHs. Desta forma, podemos analisar um par de doenças que forma um par de morbidade-comorbidade, através do diagnóstico principal e secundário. Com esta análise, pode-se avaliar se é possível a realização da predição de genes através de estudos de associação gênica entre estas doenças.

\subsubsection{Confiabilidade dos Dados}

A confiabilidade de dados de origem médica é definida como a capacidade de reproduzir a mesma informação com relação a critérios predefinidos. No caso particular de diagnósticos médicos, a confiabilidade não informa sobre a veracidade da informação, porém informa sobre a qualidade da transcrição, interpretação e da codificação da mesma. Nossa base de dados de estudos utiliza a codificação apropriada para classificações de doenças, o CID-10.

Diversos estudos sobre confiabilidade e concordância dos diagnósticos em bases de prontuários eletrônicos mostram grande variação de taxa de concordância (DEMLO; CAMPBELL; BROWN, 1978; LEBRAO, 1978). Estes problemas se devem ao fato de que a característica dessa informação é muito subjetiva. Certos casos de discordâncias desses estudos foram justificados, pois a equipe de profissionais não conseguiu selecionar o diagnóstico principal, dado que o paciente possuía mais de um diagnóstico em sua internação.

A concordância desses dados aumenta em casos com um único diagnóstico em comparação a casos de pacientes com diversas complicações. Por definição, o diagnóstico principal é o diagnóstico que, após a alta do paciente, é identificado como aquele que melhor justificou 
a internação. A estrutura de laudos das AIHs permite que o profissional da saúde selecione mais de um diagnóstico, principal e secundário, para casos de pacientes que possuam mais de uma complicação.

Os pesquisadores (VERAS; MARTINS, 1994) relataram que a concordância dos dados de diagnósticos em documentos de AIHs era mais alta quando os códigos do CID-10 eram restritos a um menor nível de agregação (três dígitos). No estudo realizado por (LEBRAO, 1978), o nível de concordância para os diagnósticos foi de 82,5\% para codificação em três dígitos, o que pode ser considerado um resultado ótimo para o nosso estudo.

Porém, vários problemas são descritos na literatura sobre a confiabilidade dos dados descritos nos laudos das AIHs. Entre eles a ilegibilidade, informações incompletas e imprecisas, o que dificulta a transcrição da informação para o Sistema de Internações Hospitalares. Em alguns casos, os profissionais responsáveis por este cadastro não possuía treinamento adequado para esta atividade.

\subsection{Filtragem dos Dados - Cálculo de Comorbidade}

Como o nível de confiabilidade e concordância aumenta quando os códigos CID-10 estão em um nível menor de agregação, prevalecemos com a análise dos códigos em somente três dígitos.

Dado que o nível de confiabilidade a partir da amostra de dados dos pares morbidadecomorbidade de nosso estudo é baixo nos dados de diagnósticos, todos os registros foram filtrados. Assim, os registros restantes deveriam representar internações contendo valores de associações de doenças maiores que a probabilidade esperada, ou seja, essas associações não deveriam ser aleatórias. Essa filtragem foi feita a partir de cálculos específicos de comorbidade.

No estudo de (ROQUE et al., 2011) foi definido um cálculo de corte para a análise de pares de doenças $a$ e $b$, a partir da seguinte fórmula:

$$
c s_{a b}=\ln \frac{O b s+1}{E x p t+1}
$$

Podemos definir a variável Expt a partir da fórmula:

$$
\operatorname{Expt}=\frac{n_{a} \times n_{b}}{n_{\text {total }}}
$$

A variável $O b s$ é definida pelo número observado de associações entre as doenças $a$ e $b$, e a variável Expt é definida pelo número esperado desta respectiva associação. O número esperado é calculado pela prevalência de cada doença no corpus atual $\left(n_{a}\right.$ e $\left.n_{b}\right)$. A soma do valor 1 em ambos, nominador e denominador da fórmula, é usada para favorecer os pares 
de doenças raras, cujas prevalências são baixas. Como temos o logaritmo na base 2 neste cálculo, os valores de corte acima de 1 restringem pares com maior coassociação.

A filtragem de dados foi realizada para os registros de internações hospitalares de todo o territorío brasileiro dentro do período de 1998 a 2011.

\subsection{Triangulação CID-10-UMLS-OMIM}

Como relatado na seção 3.1, para a coleta de genes de cada doença que forma o par de morbidade-comorbidade, utilizamos o mapeamento intermediário da UMLS, capaz de, a partir de códigos das classificações de doenças do sistema CID-10, coletar os dados referentes a genes da base OMIM que estão relacionados a estas doenças.

A UMLS fornece uma API Java que permite a manipulação e o acesso ao seu Metatesauro. Diversos métodos foram implementados para que os usuários possam usufruir com maior independência das fontes e recursos da UMLS.

Apresentamos a seguir os métodos utilizados para a realização do mapeamento CID-10OMIM:

- getCodeAtoms (código, base, filtro) : Este método tem como entrada um código de busca e a respectiva base relacionada a este código. Pode-se realizar um filtro para restringir quais bases o resultado deverá apresentar. O getCodeAtoms tem como saída os átomos que estão relacionados aos conceitos que apresentam como termo o código de entrada. O código que iremos colocar de entrada é o código de diagnóstico da doença. Ex: Q35. A base será CID-10 e não iremos restringir nenhum filtro para a execução deste método. A saída deste apresentará uma lista dos átomos ligados a termos que apresentam o código da doença. Tais átomos podem estar ligados a diferentes conceitos. Neste exemplo, temos somente um conceito relacionado a este código CID-10: $C 0008925$.

- getConceptAtoms (conceito, filtro): Após a coleta dos conceitos relacionados ao código do CID-10, a próxima etapa é a coleta dos átomos da fonte OMIM relacionados a esses conceitos coletados no último processo. Este método tem como entrada o código do conceito e um filtro de fontes de vocabulário. Como estamos interessados somente nos átomos da base OMIM, o filtro de busca será OMIM. O código do conceito será o mesmo coletado anteriormente: C0008925. A saída deste método apresentará uma lista de átomos da base OMIM que está relacionada a este conceito. Neste caso, somente um átomo é resultado do método, apresentando o seguinte código: $M T H U 000511$. Particularmente, os átomos que apresentam código com o prefixo $M T H U$ são átomos que foram construídos por métodos de agregação de diferentes átomos. De modo geral, podemos ter átomos diferentes relacionados a um 
átomo global, que neste caso, não representa um termo de uma determinada fonte de vocabulário. Estes átomos globais apresentam o prefixo $M T H U$ para a sua distinção. Eles não estão ligados a um termo específico da base em interesse, mas a uma agregação de termos construída pelo Metatesauro, por isso o prefixo $M T H U$. Quando esses átomos se apresentam, deve-se entrar em um menor grau na árvore e coletar os átomos relacionados a este átomo global, sendo que os últimos apresentarão códigos da base OMIM.

- getAtomAtomRelations (códigoAtomo, filtro): Este método tem como objetivo listar os átomos que estão relacionados a um determinado átomo. Pode-se realizar um filtro para restringir os átomos de uma determinada fonte de vocabulário. Como entrada deste método iremos passar o código do átomo que foi coletado no método anterior, A12009030 (identificador do átomo com código MT HU000511). Restringiremos os resultados para que só retornem átomos da fonte OMIM. A saída deste método lista diversos átomos ligados à base OMIM com seus respectivos códigos de seus termos. Desta forma, podemos então coletar os genes que estão relacionados às doenças dos códigos CID-10 de seus respectivos diagnósticos. Exemplo de códigos OMIM de saída: 217100, 192430, 300166, 200610, 614261, 607597, 106260, 258860, 154500.

A Figura 4.2 ilustra o fluxograma da execução dos métodos do algoritmo implementado para realizar o mapeamento dos códigos CID-10 em códigos OMIM.

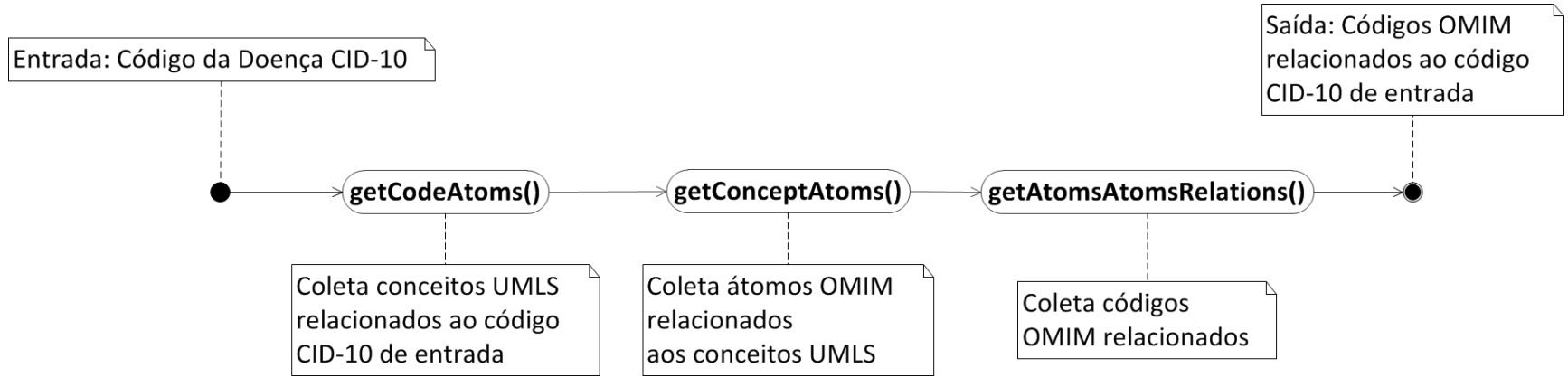

Figura 4.2: Fluxo de chamada de funções para o mapeamento CID-10-OMIM.

\subsection{Mapeamento OMIM-Símbolo de Genes}

Após a coleta dos códigos OMIM referentes às doenças estudadas, o próximo passo foi realizar o mapeamento desses códigos para símbolos de genes. O OMIM disponibiliza um arquivo chamado de morbidmap com todos os dados armazenados de sua base atual com as seguintes informações por linha do arquivo:

- nome da doença com o seu respectivo identificador OMIM; 
- símbolos genes/lócus respectivos da respectiva doença;

- identificador OMIM dos símbolos dos genes;

- localização citogenética.

A Figura 4.3 abaixo mostra a disposição das informações fenotípicas e genotípicas e seus respectivos identificadores OMIM do arquivo morbidmap:

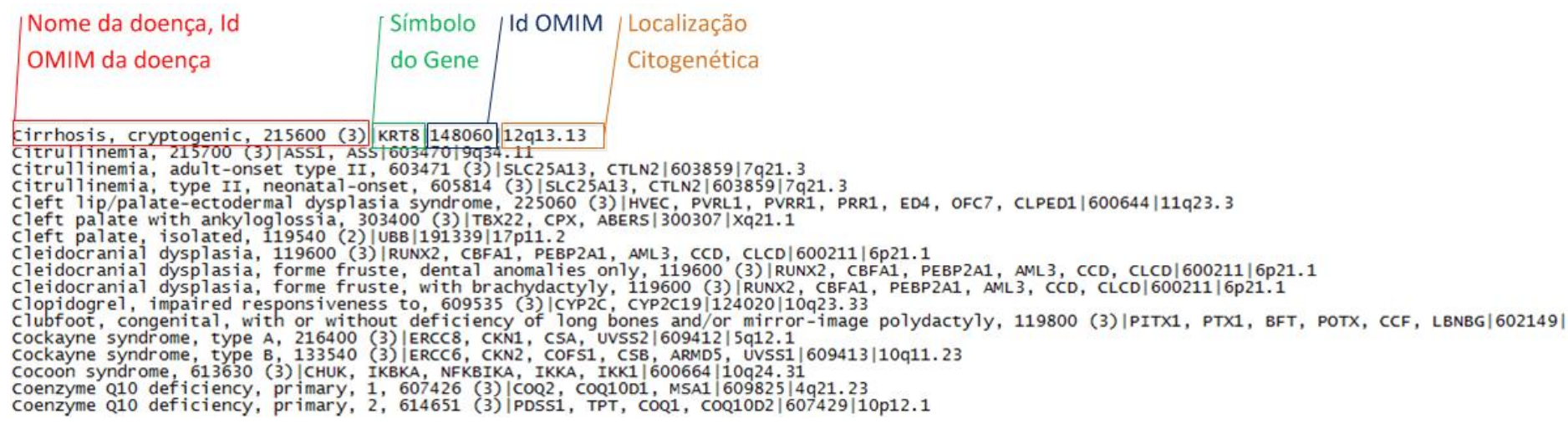

Figura 4.3: Organização estrutural do arquivo morbidmap.

A partir deste arquivo, pudemos então consultar os genes responsáveis por cada doença através dos códigos OMIM (identificadores) coletados no processo anterior. Vale observar que no processo de coleta dos códigos OMIM, os identificadores podem ser específicos para fenótipos, bem como para genótipos. Assim sendo, fizemos consultas dos genes a partir de ambos os identificadores.

\subsubsection{Gene Sets}

Após a coleta de genes através do arquivo morbidmap, pôde-se através desse processo construir conjuntos de genes de cada doença do par morbidade-comorbidade que está sendo analisado. Um novo arquivo foi formado com a listagem desses dois conjuntos de genes que foram comparados par a par através de medidas de Similaridade Semântica.

\subsection{Similaridade Semântica}

Como próxima etapa de nosso processo metodológico, foi utilizada a busca de anotações gênicas em Ontologias a fim de inter-relacionar os diferentes genes que compartilham relações entre as doenças que formam pares morbidade-comorbidade. Esta inter-relação é realizada através de medidas de Similaridade Semântica de terminologias estruturadas encontradas nas Ontologias gênicas, especificamente do Gene Ontology. Uma validação de dados, em sentido restrito, deve ser laboratorial, porém métodos computacionais podem corroborar com a validação dos resultados adquiridos. 


\subsubsection{Pacote GOSemSim-Algoritmo para Similaridade Semântica}

Para o cálculo de Similaridade Semântica dos conjuntos de genes relacionados às doenças que formam os pares morbidade-comorbidade foi utilizado um pacote do software $\mathrm{R}$ ( $\mathrm{R}$, 2014) chamado GOSemSim, derivado do conjunto de pacotes do projeto Bioconductor (YU et al., 2010a).

Diversas funções estão disponíveis neste pacote para o cálculo de Similaridade Semântica entre genes. A função de maior interesse para o projeto é a mgeneSim, que calcula a Similaridade Semântica par a par de uma lista de genes passada por parâmetro.

Após a última etapa do nosso projeto, obtemos uma lista dos genes de cada doença que forma o par morbidade-comorbidade estudado. Esta lista apresenta os símbolos de genes, porém para o cálculo de Similaridade Semântica utilizando o pacote GOSemSim, devemos converter estes símbolos de genes em identificadores da base de dados Entrez (Entrez, 2014). A base de dados Entrez fornece um sistema de consulta e recuperação de diferentes bases de dados genômicos. O sistema apresenta uma relação de todos os genes e sequências conhecidas e identificadores únicos para cada um deles. Dessa forma, muitos outros sistemas, como o pacote GOSemSim, utilizam estes identificadores para servir de referência aos genes. Para tanto, foi feito um código para realizar essa conversão, de modo que pudéssemos acessar a base de dados da Entrez para converter o nome do símbolo do gene para o identificador Entrez. O código na linguagem de programação (Python, 2014) abaixo exemplifica como essa conversão foi realizada.

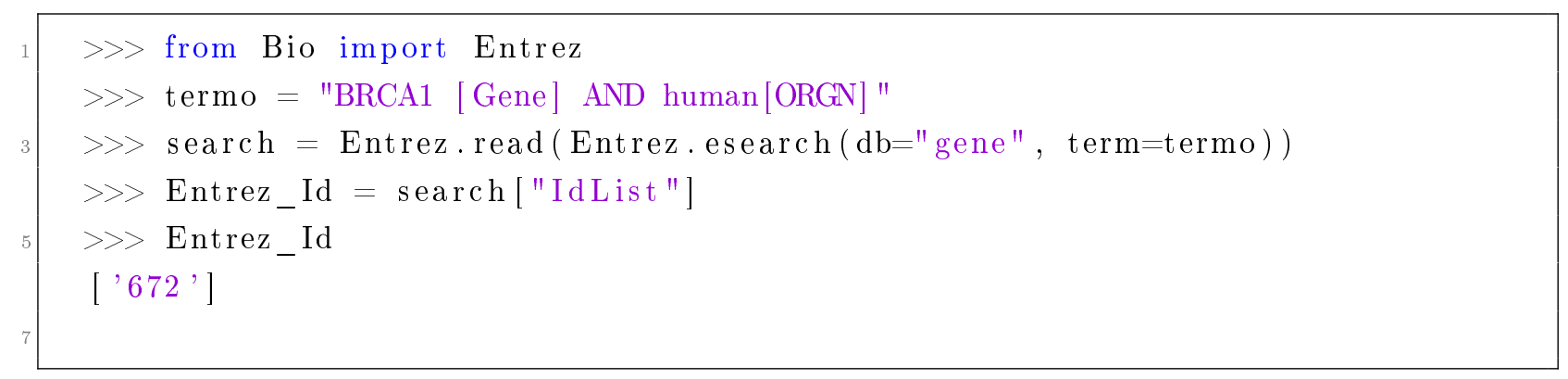

Essa conversão foi feita para toda a lista de símbolos de genes e uma nova lista com os Ids Entrez foi produzida.

Para um estudo do par morbidade-comorbidade foi montada uma única lista com os id Entrez de cada conjunto de genes do par morbidade-comorbidade.

Após a Similaridade Semântica ser calculada para a lista de genes em estudo, o resultado da função foi uma matriz onde cada gene foi comparado com o restante de genes da lista.

A linha de comando na linguagem de programação R (R, 2014) exemplifica a chamada que é feita para a o cálculo de medidas, em que a função de Lin (LIN, 1998) para Similaridade Semântica é calculada para a lista de genes passada como parâmetro, levando em conta 
termos anotados para ontologias relacionadas a processos biológicos (BP):

$>\operatorname{sim}<-$ mgeneSim ( listaGenes, ont="BP", organism="human", measure="Lin")

A Figura 4.4 ilustra como é visualizada a matriz final de Similaridade Semântica. O valor máximo de Similaridade Semântica é 1, que ocorre quando os dois genes que estão sendo comparados são iguais. Quanto mais próximo de 1 for o valor resultante, maior será a Similaridade Semântica entre os genes.

\begin{tabular}{|c|c|c|c|}
\cline { 2 - 4 } \multicolumn{1}{c|}{} & 379 & 10584 & 8625 \\
\hline 379 & 1.000 & 0.117 & 0.210 \\
\hline 10584 & 0.117 & 1.000 & 0.428 \\
\hline 8625 & 0.210 & 0.428 & 1.000 \\
\hline
\end{tabular}

Figura 4.4: Matriz de Similaridade Semântica entre os genes representados por identificadores Entrez. Os identificadores 379, 10584 e 8625 correspondem respectivamente aos símbolos de genes $A R L D 4, C O L E C 10$ e RFXANK.

\subsection{Visualização Gráfica da Matriz de Similaridade}

Podemos aplicar o escalonamento multidimensional (MDS) na matriz de distâncias. O escalonamento multidimensional é o método mais comum para quantificar a posição de um conceito em comparação a concorrentes. A técnica é baseada nas avaliações diretas de conceitos, sobre o quão semelhantes/diferentes os conceitos são um dos outros. Outra definição desta técnica é que a mesma é constituída por uma família de modelos. Neles, um conjunto de dados é representado por um conjunto de pontos em um espaço em que as relações geométricas entre estes pontos correspondem, o mais próximo possível, às relações empíricas no conjunto de dados (CARROLL; CHANG, 1970).

Em relação a este projeto, a técnica de MDS foi aplicada a esta matriz de similaridade de genes, com o objetivo de obtermos uma projeção bidimensional das distâncias entre os genes. Deste modo, a distância entre pares de genes é equivalente ao calculado na matriz de distâncias. Este é um dos processos mais utilizados para a visualização de dados, pois é capaz de reduzir as dimensões do problema e tentar preservar as informações originais. Para tanto, foi utilizado o método MDS Clássico cmdscale do pacote MASS da ferramenta estatística $\mathrm{R}$ para fazer a transformação da matriz de similaridade em dados bidimensionais. Quanto mais próximo os genes estiverem, maior será a similaridade entre eles, levando-se em conta a similaridade calculada através dos termos anotados a eles no GO, em um determinado domínio da ontologia (função molecular, componente celular ou processo biológico). Logo, com a visualização bidimensional da distância entre os genes, podemos analisar quais genes 
de cada doença do par morbidade-comorbidade apresentam maior similaridade entre eles, para podermos predizer novos genes às respectivas doenças de estudo.

\subsection{Validação dos Métodos}

Para a validação do processo do projeto, coletamos pares de doenças que formam comorbidades genéticas a partir do estudo na literatura científica e os respectivos genes que estão relacionados a esses pares de doenças morbidade-comorbidade. Assim, após a execução de todos os processos, pôde-se avaliar se os genes coletados para a validação são os mesmos que os achados através da literatura. 


\section{Capítulo 5}

\section{Resultados}

Nossos esforços se concentraram nos resultados da filtragem de dados da base das AIHs, além de realizar um estudo de validação do método proposto a partir da escolha de dois pares de morbidade-comorbidade conhecidos na literatura, bem como seus genes responsáveis. Além disso, realizamos um estudo de caso de comorbidades referentes à Fenda Palatina, aplicando o método proposto na expectativa de realizar novas predições de genes candidatos a esta doença e às suas comorbidades.

\subsection{Resultados da Filtragem de Dados}

Após a coleta de dados de internações hospitalares, foi realizado o cálculo de comorbidade descrito no Capítulo 4. Foi realizada uma filtragem desses registros, preservando-se somente os pares de doenças com valor de comorbidade maior que 1. A Tabela 5.1 mostra um resumo sobre a base de dados estudada. Esses dados se referem aos registros dentro do período de coleta de 1998 a 2011, de todo o território brasileiro.

Tabela 5.1: Valores pré-filtragem de comorbidades.

\begin{tabular}{l|r}
\hline Dado & Valor \\
\hline Total de Internações & 162.692 .255 \\
\hline Total de Internações com ambos diagnósticos & 14.238 .930 \\
\hline Total de Pares de Doenças & 429.746 \\
\hline
\end{tabular}

A Tabela 5.2 apresenta os valores da pós-filtragem dos registros de comorbidades e sua respectiva porcentagem em relação aos valores da base de dados original do período de coleta. 
Tabela 5.2: Valores pós-filtragem de comorbidades.

\begin{tabular}{l|l|l}
\hline Dado & Valor & Porcentagem \\
\hline Total de Internações Filtradas & 7.624 .576 & $\begin{array}{l}4 \% \text { em relação ao Total } \\
\text { de Internações }\end{array}$ \\
\hline Total de Pares de Doenças Filtradas & 160.362 & $\begin{array}{l}37 \% \text { em relação ao Total } \\
\text { de Pares de Doenças }\end{array}$ \\
\hline
\end{tabular}

\subsection{Validação dos Resultados}

Para a validação do método proposto, dois pares de morbidade-comorbidade foram selecionados na literatura para investigação. Estes pares foram selecionados de acordo com artigos científicos que evidenciam comprovações de relações gênicas entre as doenças que formam o par. Todos os passos metodológicos foram realizados, desde a coleta de pares de comorbidades até a visualização bidimensional dos genes candidatos de cada doença dos pares. Assim, a partir do estudo da literatura e da comparação dos resultados encontrados a partir da aplicação do método, pudemos avaliar se os achados são condizentes com evidências encontradas na literatura.

\subsubsection{Esquizofrenia x Autismo}

Diversos artigos da literatura (HALLERBACK; LUGNEGARD; GILLBERG, 2012; KING, 2011; GADOW, 2013) mostram evidências de que existe relação de comorbidade entre a Esquizofrenia e o Autismo. Pelo nosso método de cálculo de comorbidade, o par de doenças apresenta valor acima do estipulado para o corte de registros das comorbidades das AIHs, como mostra a Tabela 5.3:

Tabela 5.3: Evidência de comorbidade entre Esquizofrenia e Autismo nos registros de internaçôes hospitalares.

\begin{tabular}{l|l|r}
\hline Diagnóstico Principal & Diagnóstico Secundário & Comorbidade \\
\hline Esquizofrenia residual & Autismo infantil & 1,24 \\
\hline Esquizofrenia hebefrênica & Autismo atípico & 1,09 \\
\hline
\end{tabular}

Após o processo de mapeamento dos códigos CID-10 das doenças Esquizofrenia e Autismo em códigos OMIM através da UMLS, foi possível apresentar a relação de códigos OMIM relacionados a cada código de doença. Através da relação de códigos OMIM, foi montada a lista de genes responsáveis por cada doença, a partir da busca dos códigos no arquivo morbidmap. A Tabela 5.4 relaciona os genes responsáveis para cada doença.

A Figura 5.1 ilustra a visualização bidimensional da distância entre os genes coletados como candidatos para ambas as doenças. O cálculo de distância entre eles é realizado através dos valores resultantes do método de Similaridade Semântica de (LIN, 1998), considerando a ontologia de Processos Biológicos. Os símbolos de genes em vermelho são os associados à 
Tabela 5.4: Relação de genes resposáveis para Esquizofrenia e Autismo.

\begin{tabular}{|c|c|c|}
\hline Código CID-10 & Descrição da Doença & Genes \\
\hline $\begin{array}{l}\text { F20 } \\
\text { F20.1 } \\
\text { F20.5 }\end{array}$ & Esquizofrenia & $\begin{array}{r}\text { AKT1 } \\
\text { APOL2 } \\
\text { APOL4 } \\
\text { ATP2A2 } \\
\text { CHI3L1 } \\
\text { COMT } \\
\text { DAO } \\
\text { DAOA } \\
\text { DISC1 } \\
\text { DISC2 } \\
\text { DRD3 } \\
\text { DTNBP1 } \\
\text { GP39 } \\
\text { HTR2A } \\
\text { MTHFR } \\
\text { RTN4R } \\
\text { SCZD11 } \\
\text { SCZD12 } \\
\text { SCZD2 } \\
\text { SCZD3 } \\
\text { SCZD5 } \\
\text { SCZD6 } \\
\text { SCZD7 } \\
\text { SCZD8 } \\
\text { SYN2 }\end{array}$ \\
\hline $\begin{array}{l}\text { F84 } \\
\text { F84.0 } \\
\text { F84.1 }\end{array}$ & Autismo & $\begin{array}{r}\text { AUTS1 } \\
\text { AUTS5 } \\
\text { CSS } \\
\text { DPYD } \\
\text { IFNG } \\
\text { NHS } \\
\text { PTEN } \\
\text { SCN8A } \\
\text { TSC1 } \\
\text { TSC2 }\end{array}$ \\
\hline
\end{tabular}

Esquizofrenia, enquanto que os em preto associados ao Autismo. Pode-se perceber uma alta aproximação entre os genes IFNG, candidato ao Autismo com o gene DRD3, candidato à Esquizofrenia. Para validar nosso método, foram levantados dados da literatura que pudessem levar à discussão a hipótese de que ambos os genes pudessem ser compartilhados entre as doenças estudadas.

Transtornos do espectro autista, ou a sigla ASD do termo em inglês Autism Spectrum Disorder, são um grupo heterogêneo de doenças do desenvolvimento neural que se manifestam no início da infância. Indivíduos com ASD apresentam um grau variável de danos 


\section{Esquizofrenia x Autismo}

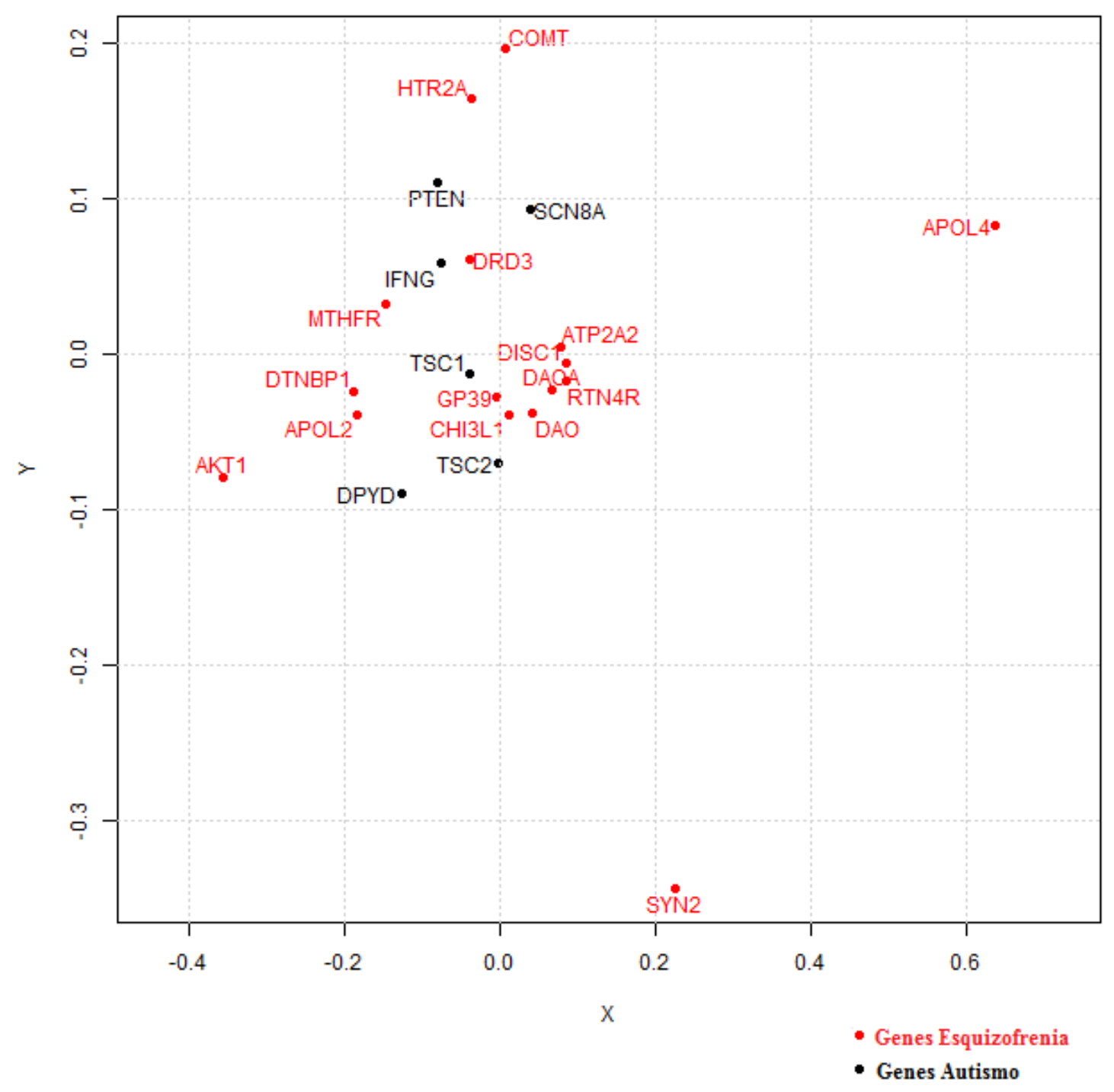

Figura 5.1: Visualização Bidimensional de distâncias entre os genes relacionados à Esquizofrenia e ao Autismo.

sociais, déficits na linguagem e comunicação e comportamentos estereotipados e repetitivos. Um estudo de (GOINES et al., 2011) relata que anomalias imunológicas são associadas em indivíduos com doenças no espectro autista. Foi realizada uma análise nesse estudo para entender se o perfil imunológico materno na gravidez pode estar associado com o risco de se ter uma criança com ASD ou outra doença neurológica. Como resultado da pesquisa, um perfil elevado do soro de IFN-g, IL-4 e IL-5 foi mais comum em mulheres que deram à luz uma criança diagnosticada com ASD. Sabe-se que o gene IFNG codifica membros do tipo 2 da família interferon gamma.

Pacientes com Esquizofrenia são caracterizados por um distúrbio profundo em cognição e funcionamento social. Da mesma forma que ocorre com o Autismo, já foi sugerido que uma 
disfunção imunológica pode contribuir para a etiologia multifatorial da Esquizofrenia. Um estudo feito por (KIM et al., 2012) mostrou que polimorfismos no gene IFNG são associados à Esquizofrenia. Esses resultados sugerem que IFNG e as proteínas afetadas pelo gene podem participar na patogênese tanto de Autismo como de Esquizofrenia.

Já em pesquisa realizada por (URRACA et al., 2011) podemos ver um efeito sinergético de polimorfismos no gene DRD3 em casos de Esquizofrenia em pacientes mexicanos. Da mesma forma, (KROM et al., 2009) realizaram uma pesquisa investigando 132 genes candidatos para casos de transtorno no espectro autista e concluiu-se que o gene DRD3 é relacionado ao comportamento estereotipado, tendências a efeitos colaterais de remédios psicóticos e desordens de movimentação. Isto sugere que mutações neste gene apresentam importantes implicações clínicas para a ASD.

Foi também verificado no interatoma humano (HPRD) (PRASAD et al., 2009) se existe ligação entre os genes IFNG e DRD3 que possam validar o método de aproximação de ambos os genes, como foi apresentado no gráfico de distâncias acima. A Figura 5.2 ilustra a via de ligação entre os mesmos.

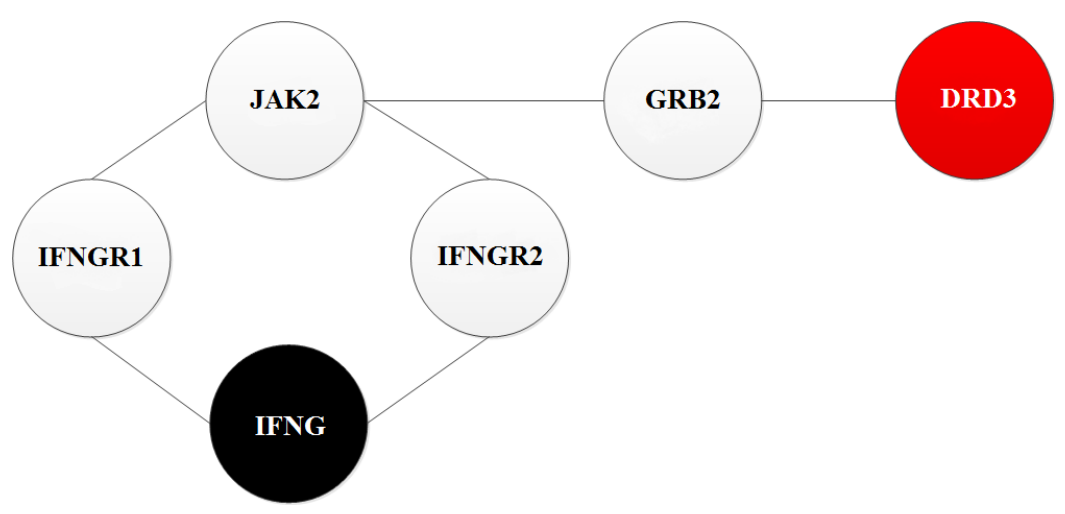

Figura 5.2: Via de interação entre os genes IFNG e DRD3.

Podemos observar, pela validação na literatura e no interatoma, que os genes IFNG e DRD3 podem ser candidatos às duas doenças analisadas. Tal validação mostra também que a ligação de ambos os genes, através de vias no interatoma, pode estar relacionada à dinâmica entre mutações destes genes. Esta dinâmica pode favorecer o surgimento desta comorbidade.

\subsubsection{Macrocefalia x Autismo}

Na análise dos genes candidatos a Autismo da literatura, foi observada uma alta quantidade de artigos relacionados à associação de Macrocefalia e Autismo através do gene PTEN (CLIPPERTON-ALLEN; PAGE, 2014).

Na etapa de análise de comorbidades a partir dos dados filtrados das AIHs do SUS, não foi evidenciado nenhum registro de internação hospitalar com ambos os diagnósticos de Macrocefalia e Autismo entre os campos principal e secundário. Tal fato gerou a impossibilidade 
de validar o processo de filtragem de comorbidades. Porém, coletamos os genes candidatos de ambas as doenças através do mesmo processo metodológico anterior e verificamos se, nos resultados finais, ambas as doenças confirmavam o compartilhamento do gene PTEN entre a lista de genes candidatos.

A Tabela 5.5 relaciona os genes responsáveis pela Macrocefalia e Autismo coletados a partir do processamento de mapeamento da UMLS e encontrados através do arquivo morbidmap. Pode-se notar que ambos os conjuntos de genes responsáveis apresentam o símbolo do gene PTEN.

O gráfico de distâncias da Figura 5.3 também ilustra o resultado positivo do processo. O gene PTEN aparece para ambas as ocorrências, tanto para Autismo como para Macrocefalia, o que pode ser constatado pela sobreposição das cores relacionadas a ambas as doenças.

\subsection{Resultados do Estudo de Caso}

Foi realizado um estudo de caso de comorbidades de Fenda Palatina (CID-10: Q35) com o objetivo de obter a expansão de genes candidatos para as doenças que formam os pares de morbidade-comorbidade. Da mesma forma que a apresentada na Seção 5.2, foram coletados dados na literatura que pudessem sugerir que os genes propostos como candidatos possuem evidências que os relacionassem com as doenças estudadas.

A seguir, apresentamos o levantamento bibliográfico que realizamos sobre a Fenda Palatina, seus possíveis genes candidatos e comorbidades conhecidas.

Anormalidades craniofaciais estão entre os defeitos de nascimento mais comuns. O mais frequente destes são as fendas orofaciais, fenda labial com ou sem Fenda Palatina (CL(P), do termo em inglês Cleft lip with/without Cleft Palate). CL(P) resulta em complicações que afetam a alimentação, fala, audição e desenvolvimento psicológico. O tratamento da doença requer intervenções multidisciplinares. Na idade de aquisição da fala, terapias são normalmente necessárias para corrigir problemas resultantes de defeitos musculares causados pela fenda. Com o crescimento do indivíduo, defeitos no desenvolvimento dentário requerem tratamento cirúrgico. As séries de tratamentos desde o nascimento até a idade adulta é desgastante para o paciente, família e sociedade. Desta forma, existe um grande esforço colaborativo para compreender a etiologia da Fenda Palatina a fim de predizer a sua ocorrência e prevení-la (KOHLI; KOHLI, 2012).

Esta anomalia congênita de etiologia multifatorial (com contribuição genética e ambiental) apresenta prevalência entre 1/700 e 1/1000 nascidos vivos (GROSEN et al., 2011). Quase metade de todos os nascimentos com Fenda Palatina ocorre em crianças com outras anomalias congênitas, fato que favorece nossa abordagem. Assim, podemos abranger comorbidades que apresentam causas genéticas e estudar suas ocorrências, relações e associações 
Tabela 5.5: Relação de genes resposáveis para Macrocefalia e Autismo.

\begin{tabular}{|c|c|c|}
\hline Código CID-10 & Descrição Doença & Genes \\
\hline Q75.3 & Macrocefalia & $\begin{array}{r}\text { ADK } \\
\text { AKT1 } \\
\text { ARSB } \\
\text { CCCSX } \\
\text { COL2A1 } \\
\text { EZH2 } \\
\text { FGFR3 } \\
\text { GLI3 } \\
\text { GNAQ } \\
\text { HDAC6 } \\
\text { HSD17B4 } \\
\text { IGBP1 } \\
\text { INPP5E } \\
\text { ISPD } \\
\text { JBTS2 } \\
\text { L1CAM } \\
\text { LRSL } \\
\text { MAN2B } \\
\text { MKS2 } \\
\text { PAPA } \\
\text { PDSS1 } \\
\text { PTEN } \\
\text { SHOC2 } \\
\text { SNX10 } \\
\text { SOST } \\
\text { TBC1D7 } \\
\text { TMEM216 } \\
\text { TPT }\end{array}$ \\
\hline $\begin{array}{l}\text { F84 } \\
\text { F84.0 } \\
\text { F84.1 }\end{array}$ & Autismo & $\begin{array}{r}\text { AUTS1 } \\
\text { AUTS5 } \\
\text { CSS } \\
\text { DPYD } \\
\text { IFNG } \\
\text { NHS } \\
\text { PTEN } \\
\text { SCN8A } \\
\text { TSC1 } \\
\text { TSC2 }\end{array}$ \\
\hline
\end{tabular}

gênicas a partir de registros da literatura.

Apesar da complexidade da etiologia da doença, alguns fatores genéticos e riscos ambientais foram identificados. Estudos de associações têm mostrado uma evidência estatística significativa para genes candidatos como o IRF6 (RAHIMOV et al., 2008) e o FOXE1 (DIXON et al., 2011). Outros genes candidatos sugerem participar de funções incluindo o 


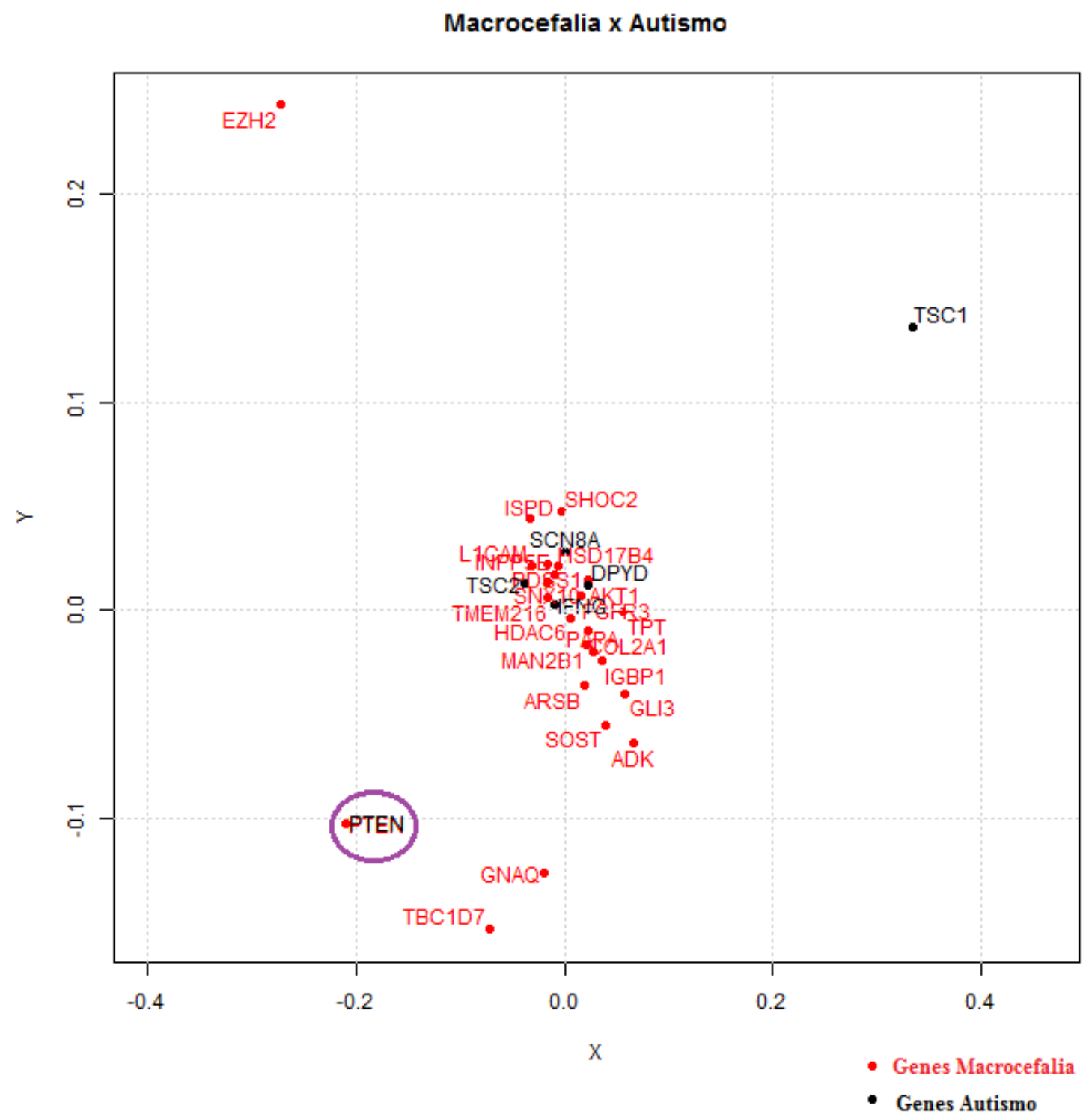

Figura 5.3: Visualização Bidimensional de distâncias entre os genes relacionados à Macrocefalia e Autismo. O destaque em roxo mostra a associação do gene PTEN tanto para Macrocefalia como para Autismo.

BMP4, TP63 (SCAPOLI et al., 2008), JAG2 (RILEY et al., 2007), fatores de crescimento de fibroblastos e seus receptores (FGFs, FGFRs) (RILEY et al., 2007), receptor de poliovírus 1 (PVRL1) (TURHANI et al., 2005; AVILA et al., 2006), proteína secretória rica em cisteína 2 (CRISPLD2), MSX1 (JEZEWSKI et al., ), UBB (ANDRIEUX et al., 2007) e OFD1 (JUGESSUR et al., 2012).

Estudos de Associação de Genômica Ampla (GWAS) também identificaram novos genes candidatos e regiões que são associadas à fenda labial com ou sem Fenda Palatina. O primeiro GWAS para CL(P), identificou uma forte associação a marcadores do gene do lócus 8q24.21 (BIRNBAUM et al., 2009) numa amostra alemã de controle, que foi replicado noutro estudo de europeus (GRANT et al., 2009). Em uma extensão do estudo alemão, (MANGOLD et al., 
2010) reportaram dois novos lócus associados a CL(P) não sindrômica no 17q.22 e 10q25.3. Um GWAS feito em grupos de casos parentais de CL(P) mostrou evidência de associação e ligação de nível de significância genômica para o cromossomo 8q24 e para IRF6 (BEATY et al., 2010) . No mesmo caso parental de estudo, dois outros lócus com evidência para associação de nível de significância genômica foram identificados dentro ou perto de dois novos genes candidatos: ABCA4 em 1p22.1 e MAFB em 20q.12. Eles também relataram 3 genes candidatos potenciais onde marcadores apresentaram significância genômica: PAX7 em .36, VAX1 em 10q25.3, e NTN1 em 17p.13.

Um estudo de replicação usado em uma população de mesoamericanos revelou uma associação significante de CL(P) para IRF6, 8q24 e 10q25 usando análises de associações simples de SNPs (ROJAS-MARTINEZ et al., 2010). Similarmente, outro estudo de replicação na Estônia relatou uma associação significante com um SNP em 10q25, confirmando sua associação com CL(P) na sua população báltica (NIKOPENSIUS et al., 2010).

Alguns fatores ambientais também foram estudados em pesquisas. (ROOIJ et al., 2001) encontraram evidências de que o genótipo GSTT1 (enzima envolvida na biotransformação de compostos halogenados do cigarro), quando combinado com o ato de fumar, pode aumentar o risco do feto apresentar Fenda Palatina. (MUNGER et al., 1996) mostraram que o uso de bebidas alcoólicas durante a gestação aumenta o risco de Fenda Palatina em 1,5 a 4,7 vezes. Além destas evidências, o uso de ácido fólico e multivitaminas, esteroides e anticonvulsivantes podem estar associados a casos de CL/P (GREWAL et al., 2008).

$\mathrm{CL}(\mathrm{P}) \mathrm{s}$ podem ser síndromes isoladas ou associadas. Diversos estudos apontam quais síndromes podem estar associadas a fendas orofaciais. Alterações como a trissomia do cromossomo 13 (Síndrome de Patau), trissomia de 18 (Sindrome de Edwards), trissomia do 21 (Síndrome de Down), e a monossomia 4p podem estar associadas à fenda labial com/sem Fenda Palatina (STEVENSON; HALL; GOODMAN, 1993). Além destas, doenças de entidades monogênicas mendelianas como Holoprosencefalia (ausência do pré-maxilar, hipotelorismo, ciclopia) e a Síndrome de Van der Woude (geralmente a mais associada a CL/P) também são encontradas na literatura como comorbidades de Fenda Palatina.

Devido à presença de muitos genes candidatos à Fenda Palatina, temos que esta doença é interessante ao nosso estudo porque podemos, através dela, explorar quais genes candidatos podem compartilhar diferentes patologias que fazem parte das comorbidades da patologia em questão. Além disso, buscando uma análise das comorbidades e seus genes candidatos, podemos acrescentar conhecimento sobre novos genes que podem estar relacionados por compartilharem comorbidades entre si.

Foi realizada a pesquisa de doenças que compartilham diagnósticos com a Fenda Palatina em registros filtrados de internações hospitalares, a partir do SIH, durante o período de 1998 a 2011, em todo o território brasileiro. A Tabela 5.6 apresenta as principais doenças com maiores valores do cálculo de comorbidade da amostra. 
Tabela 5.6: Principais doenças associadas à Fenda Palatina (Q35).

\begin{tabular}{l|l|r}
\hline CID-10 & Descrição & Comorbidade \\
\hline M86.1 & Outra osteomielite aguda & 5,94 \\
\hline M16.9 & Coxartrose não especificada & 5,83 \\
\hline J32.9 & Sinusite crônica não especificada & 4,69 \\
\hline G47.3 & Apneia do sono & 2,38 \\
\hline Q53.1 & Testículo não-descido, unilateral & 1,31 \\
\hline Q70.9 & Sindactilia não especificada & 1,30 \\
\hline Q05.3 & Espinha bífida sacra com hidrocefalia & 1,09 \\
\hline Q69.9 & Polidactilia não especificada & 1,03 \\
\hline
\end{tabular}

A partir de todo o processamento de triangulação para a transformação dos códigos CID10 em ids referentes à base OMIM pelo UMLS, pudemos coletar genes e fenótipos referentes a cada doença. A Tabela 5.7 mostra alguns genes associados às doenças estudadas.

A partir da coleta dos símbolos de genes e conversão para identificadores da base de dados Entrez, foram realizados os cálculos de similaridade e as montagens das respectivas matrizes para todos os pares de doenças que compartilhavam internações com Fenda Palatina. A seguir, mostramos as visualizações bidimensionais das distâncias entre os genes coletados para cada uma das doenças e suas respectivas análises.

\subsubsection{Fenda Palatina x Coxartrose não especificada}

A Figura 5.4 e as posteriores ilustram a distância entre os genes coletados para Fenda Palatina e a doença em estudo. Os símbolos de genes de cor vermelha são referentes aos genes de Fenda Palatina, enquanto os em preto são referentes à doença que forma par de comorbidade com a Fenda Palatina. Neste caso, os genes relacionados à Coxartrose.

(MELKONIEMI et al., 2003) verificaram que o gene COL11A1 pertence a uma coleção de genes candidatos à Fenda Palatina, como ilustrado na Figura 5.4. Podemos verificar também que em estudos como o realizado por (IKEDA et al., 2002), o gene COL9A3 é considerado um dos genes candidatos à Coxartrose, também ilustrado na figura. Sabemos que ambos os genes estão associados à formação de colágeno. Assim, ambas as doenças podem estar conectadas, ou seja, serem pares de comorbidades por mutações que afetam processos biológicos responsáveis pela formação de colágeno no organismo. A Figura 5.5 mostra como é a ligação entre ambos os genes estudados no interatoma e sua respectiva via de interação entre eles.

Podemos predizer que ambos os genes podem ser compartilhados para as duas doenças analisadas. Além disso, podemos também inferir que a mutação em um gene pode afetar sua via de interação com outros genes, favorecendo o aparecimento da outra doença e assim o surgimento do par morbidade-comorbidade. 
Tabela 5.7: Genes relacionados às doenças.

\begin{tabular}{|c|c|c|}
\hline CID-10 & Descrição & Genes Coletados \\
\hline Q35 & Fenda Palatina & 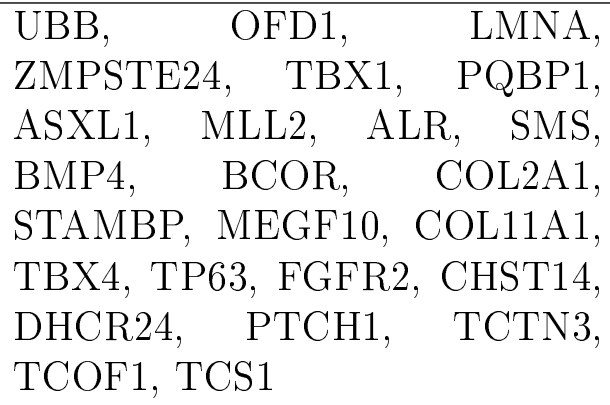 \\
\hline M16.9 & $\begin{array}{l}\text { Coxartrose não especi- } \\
\text { ficada }\end{array}$ & $\begin{array}{l}\text { COL9A3, SMAD3, } \\
\text { GDF5 }\end{array}$ \\
\hline J32.9 & $\begin{array}{l}\text { Sinusite crônica não } \\
\text { especificada }\end{array}$ & $\begin{array}{l}\text { DNAI1, TAPBP, BLNK, PCD, } \\
\text { CCDC103, MGP, TAP1, TAP2, } \\
\text { CD779B }\end{array}$ \\
\hline G47.3 & Apneia do sono & WDR45, PAFAH1B1, EHMT1 \\
\hline M86.1 & $\begin{array}{l}\text { Outra } \quad \text { osteomielite } \\
\text { aguda }\end{array}$ & $\begin{array}{l}\text { TCIRG1, } \\
\text { FAM134B }\end{array}$ \\
\hline Q53.1 & $\begin{array}{l}\text { Testículo não-descido, } \\
\text { unilateral }\end{array}$ & $\begin{array}{l}\text { ANKRD11, AKR1C2M INSL3, } \\
\text { STS, KFSDX, CREBBP, PR- } \\
\text { KAR1A, CUL4B, CAR, FTO, } \\
\text { MECP2, CDR, MPTPS2, } \\
\text { PTPN11, CDKN1C, SEC23A, } \\
\text { NAA10, DKC1, NIPBL, NSD1, } \\
\text { AKR1C, HDAC8, MCOPS8, } \\
\text { ATPAF2 }\end{array}$ \\
\hline Q05.3 & $\begin{array}{l}\text { Espinha bífida sacra } \\
\text { com hidrocefalia }\end{array}$ & $\begin{array}{l}\text { HOXD13, SPD, VANGL2, NF1, } \\
\text { LMX1B, CCL2, FUZ, RBM8A }\end{array}$ \\
\hline Q69.9 & $\begin{array}{l}\text { Polidactilia não espe- } \\
\text { cificada }\end{array}$ & $\begin{array}{ll}\text { GDF5, MKS, CREBBP, MKS1, } \\
\text { RECQ2, PORC, } & \text { TFAP2A, } \\
\text { RECQL3, HESC1, } & \text { PIK3CA, } \\
\text { WHAS, MDS, LBR } & \end{array}$ \\
\hline Q70.9 & $\begin{array}{l}\text { Sindactilia não especi- } \\
\text { ficada }\end{array}$ & 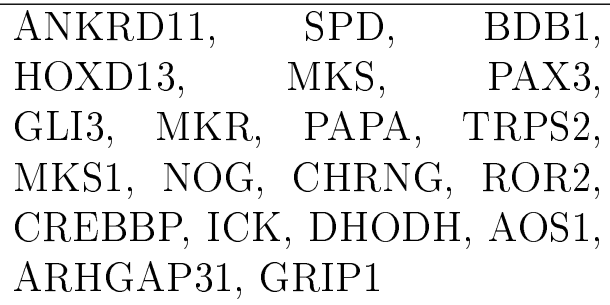 \\
\hline
\end{tabular}

\subsubsection{Fenda Palatina $x$ Sinusite crônica não especificada}

(ALROMAIH et al., 2013) realizaram um estudo mostrando uma grande significância de associação entre os genes CD8A e TAPBP em doenças relacionadas à Sinusite crônica.

O TAPBP é conhecido por realizar o transporte de antígenos entre a membrana do retículo endoplasmático. Assim sendo, suas mutações levam a doenças alérgicas como a sinusite, evidência ilustrada na Figura 5.6. 
Fenda Palatina x Coxartrose não especificada

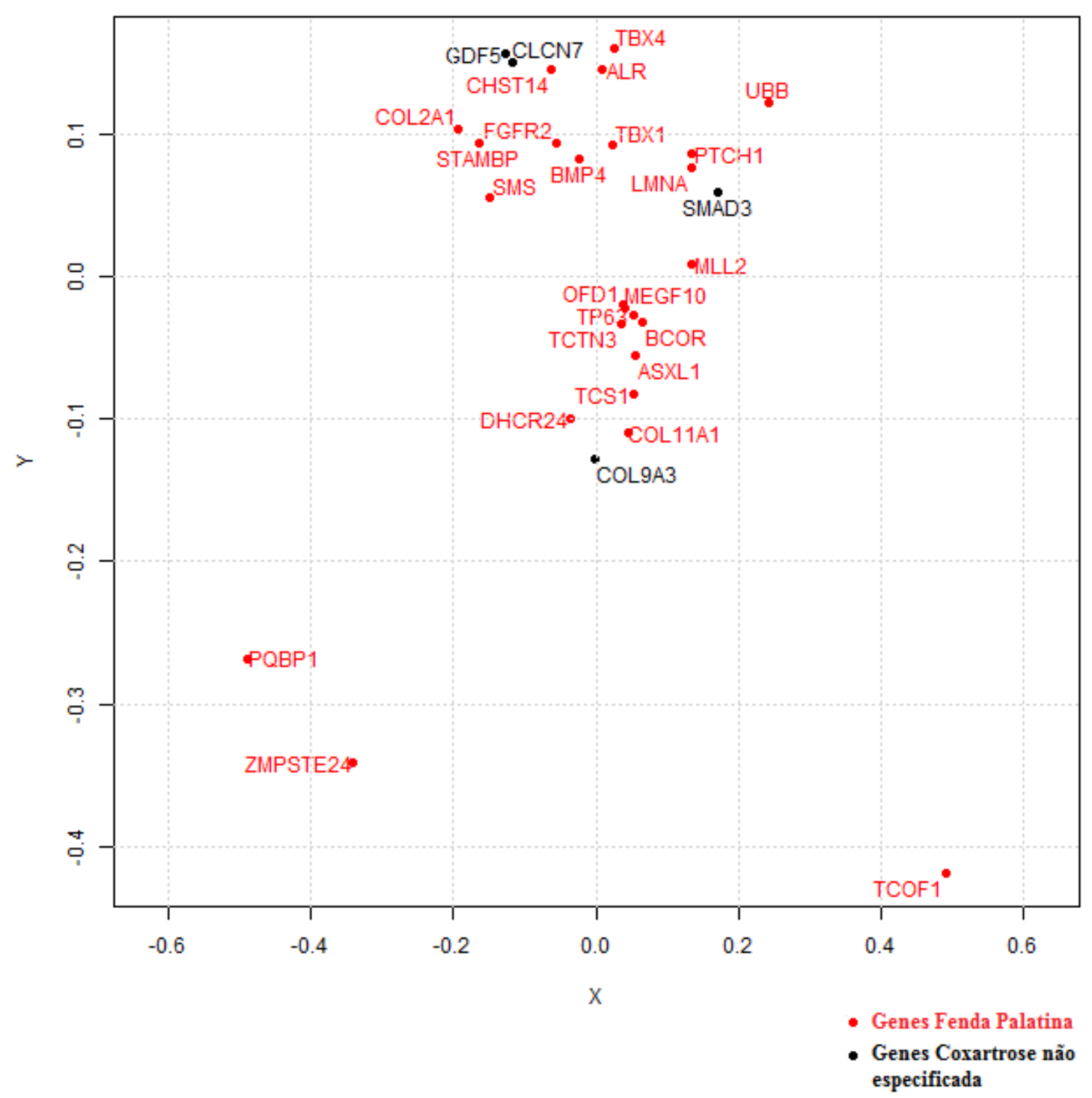

Figura 5.4: Visualização Bidimensional de distância entre os genes relacionados à Fenda Palatina e Coxartrose.

Na pesquisa realizada por (GADOLA et al., 2000), uma análise é feita sobre a Síndrome de Deficiência em TAP. Tal deficiência é causada por defeitos nas expressões dos genes TAP1 e TAP2 e a mesma se manifesta pelas frequentes infecções bacterianas, sinusites crônicas e otites médias, sendo que tais genes podem ser observados no gráfico como sendo associados à Sinusite.

(PANIZZI et al., 2012) realizaram um estudo com indivíduos que apresentavam mutações recessivas no gene CCDC103 e todos possuíam a doença Discinesia Ciliar Primária, contendo como principais sintomas a Sinusite, a Bronquiectasia e infecções do trato respiratório. Essa doença é caracterizada por defeitos nas células ciliares que estão presentes no trato respiratório. (PASCHUALINOTO; AMARAL, 2010) analisaram a hipótese do gene OFD1 estar 


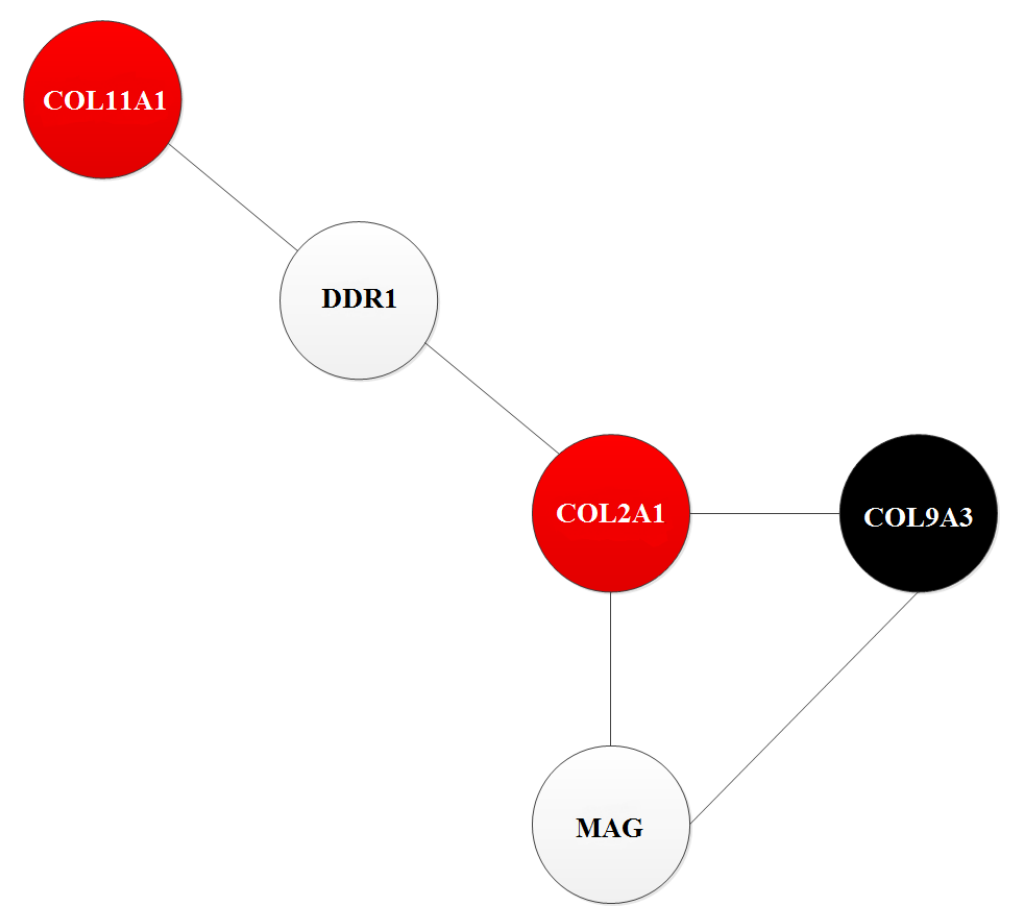

Figura 5.5: Via de interação entre os genes COL9A3 e COL11A1.

presente na associação à doença anterior. Sabe-se que mutações neste gene são responsáveis por doenças orofaciais, como a Fenda Palatina. (ROMIO et al., 2004) mostraram que o produto gênico de OFD1 localiza-se no centrossomo e promove a formação ciliar primária, fato que corrobora para a associação entre complicações como a Sinusite. Analisando o gráfico 5.6, vemos a proximidade do gene OFD1 entre os genes associados à Sinusite. Esta proximidade pode ser relevante, como mostrada através dessas duas últimas evidências da literatura.

\subsubsection{Fenda Palatina x Apneia do Sono}

Podemos analisar no gráfico da Figura 5.7, que os genes mais conhecidos por estarem presentes em distúrbios do sono são WDR45, PAFAH1B1 e EHMT1.

Na pesquisa realizada por (JONES et al., 2008), foi realizado um estudo dos transcritos com alta expressão para fraqueza e distúrbios do sono, apresentando entre vários genes, a alta expressão do gene PAFAH1B1. Além desta pesquisa, em um estudo feito por (HAYFLICK et al., 2013), o gene WDR45, conhecido por ser responsável pela degeneração neuronal com acúmulo de ferro, foi descrito como pertencente a família de proteínas que incluem as proteínas codificadas pelo PAFAH1B1, proteína importante para a sobrevivência neuronal. A degeneração neuronal com acúmulo de ferro apresenta entre outras características a presença de distúrbios fortes de sono.

Recentemente 3 estudos cromossômicos em arrays foram realizados em 15 pacientes não relacionados com retardo no desenvolvimento intelectual e outros defeitos congênitos (HYON 
Fenda Palatina x Sinusite Crônica Não Especificada

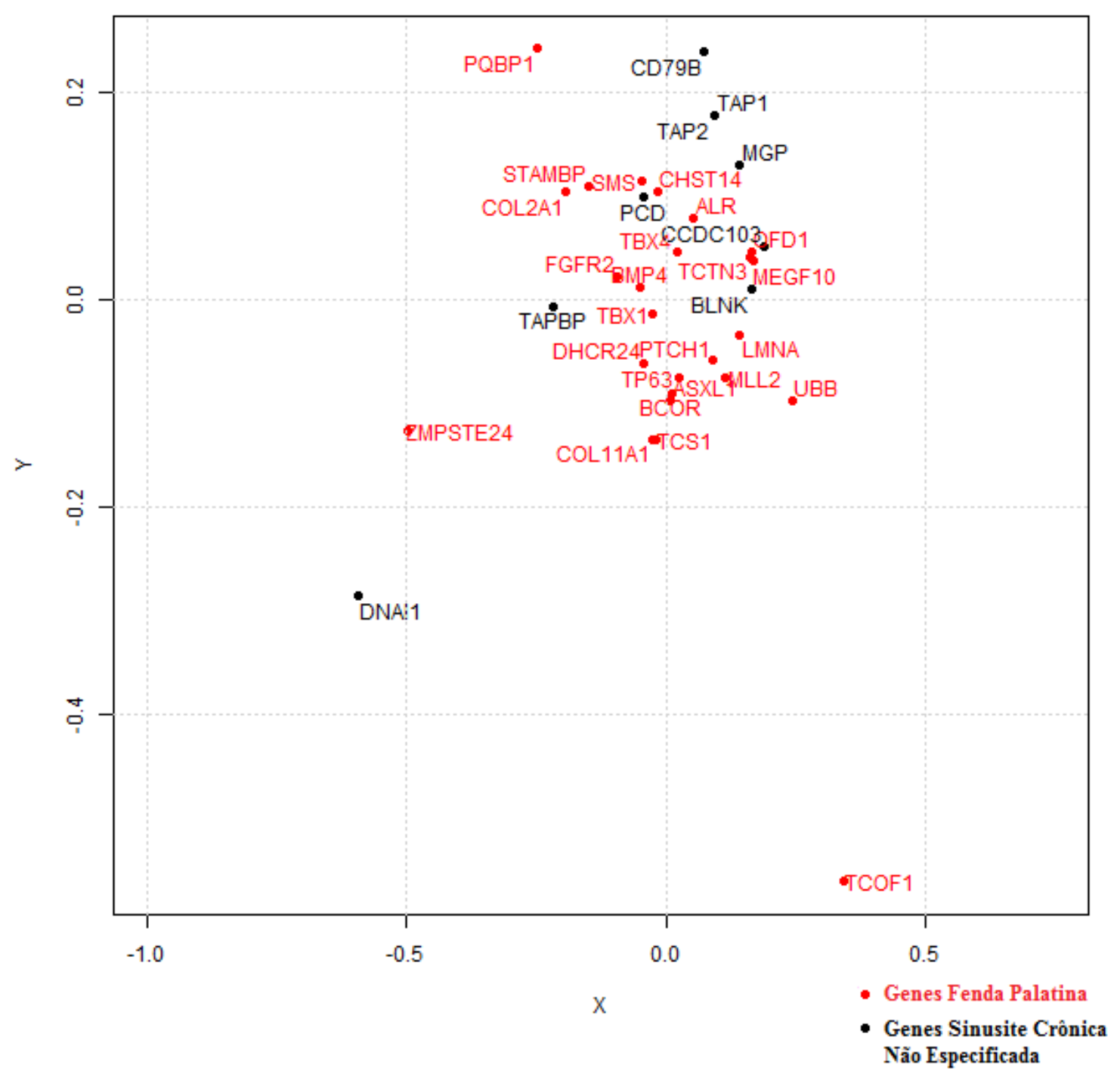

Figura 5.6: Visualização Bidimensional de distâncias entre os genes relacionados à Fenda Palatina e Sinusite.

et al., 2011). Os primeiros 7 casos levaram a identificação de novas desordens genômicas incluindo o gene PAFAH1B1. As características principais fenotípicas incluíram defeitos orofaciais, como a Fenda Palatina. Tais estudos mostram, que este gene pode ser forte candidato à Fenda Palatina.

\subsubsection{Fenda Palatina x Osteomielite}

No gráfico da Figura 5.8 podemos analisar que os genes TCIRG1, DNMT1 e NTRK1, coletados no processo como responsáveis pela Osteomielite, possuem maiores associações, em termos de processos biológicos, com os genes relacionados à Fenda Palatina.

(RAPP et al., 2013) descreveram que a insensibilidade congenital à dor com anidrose é 
Fenda Palatina x Apneia do Sono

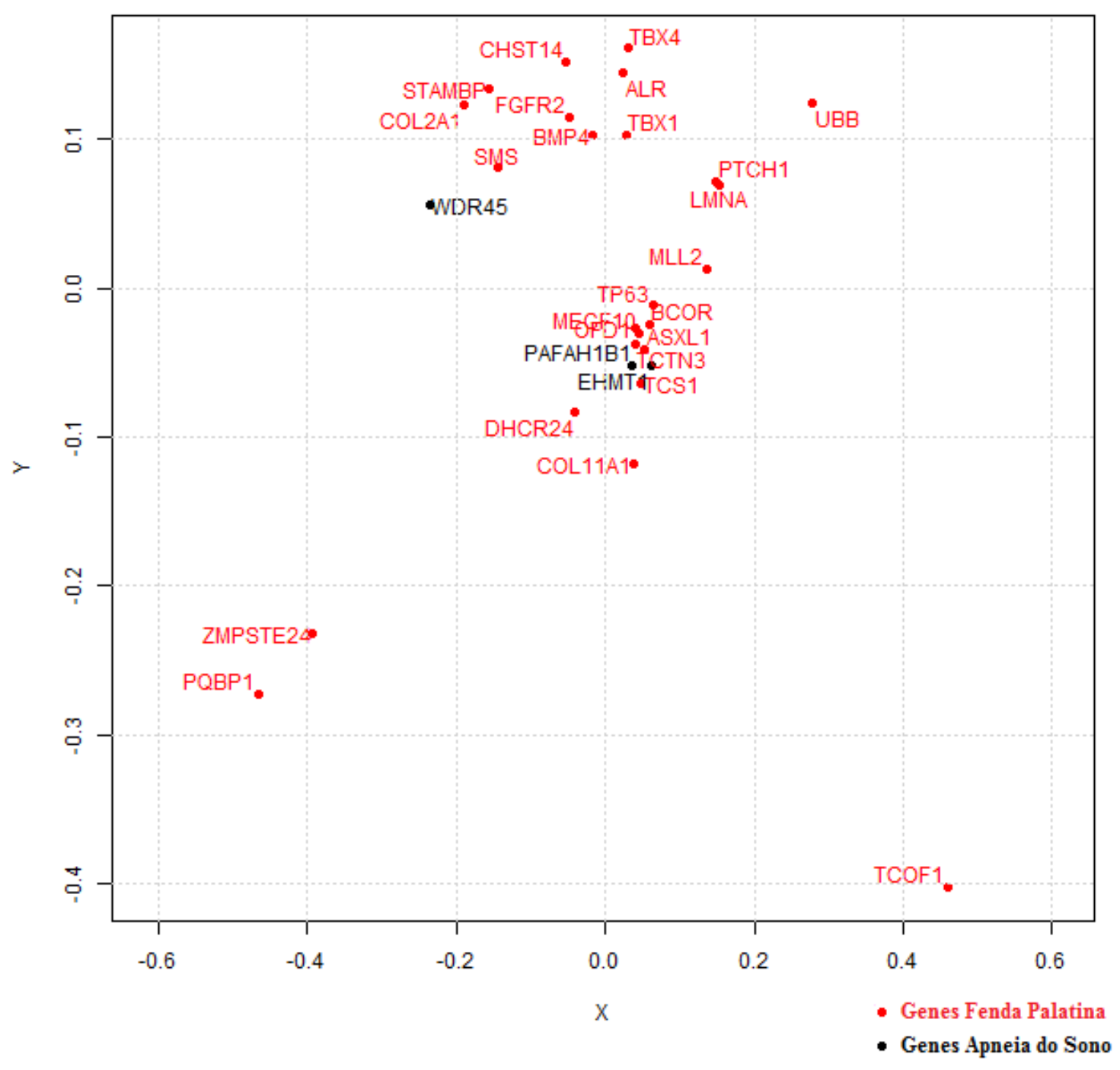

Figura 5.7: Visualização Bidimensional de distâncias entre os genes relacionados à Fenda Palatina e Apneia do Sono.

uma doença autossômica recessiva causada por mutações no gene NTRK1. Este codifica o receptor para o fator de crescimento do nervo. Algumas complicações desta doença já foram relatadas na literatura, o que inclui a Osteomielite, conhecida por infecções nos ossos.

(GAO et al., 2013) relataram que pacientes que apresentavam insensibilidade congenital e defeitos faciais, como a Fenda Palatina, possuíam uma heterozigose composta no gene NTRK1.

Analisando o estudo anterior, vemos que há uma probabilidade do gene NTRK1, responsável por síndromes que apresentam complicações como a Osteomielite, também estar associado a defeitos orofaciais como a Fenda Palatina.

A Figura 5.9 ilustra a ligação na via de interação entre os genes NTRK1 e os genes 
Fenda Palatina x Osteomielite

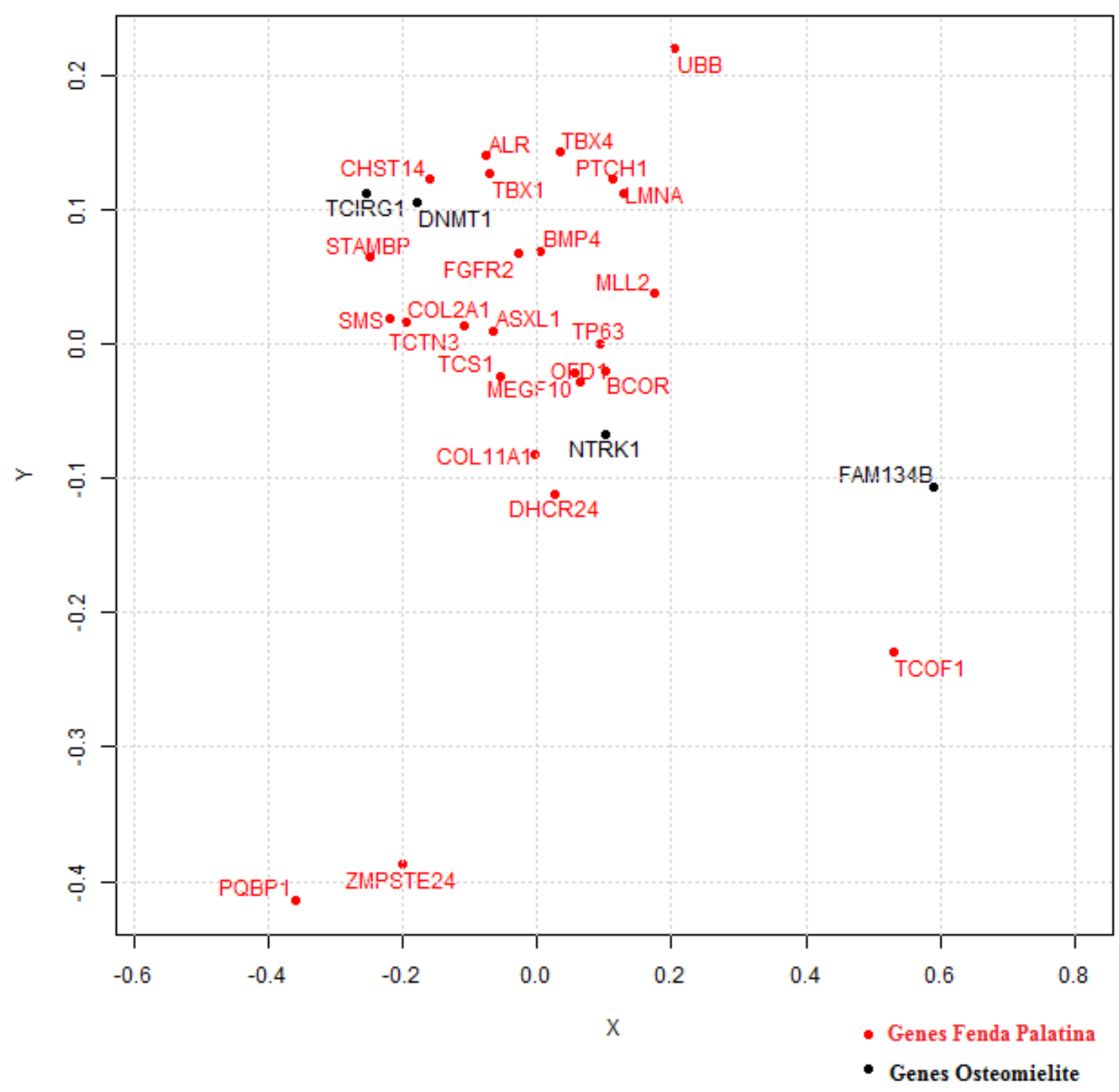

Figura 5.8: Visualização Bidimensional de distâncias entre os genes relacionados à Fenda Palatina e Osteomielite.

de Fenda Palatina. Esta ligação confirma que pode haver associação entre estes genes que favorecem tal comorbidade e que ela pode promover o mesmo a gene candidato à Fenda Palatina.

\subsubsection{Fenda Palatina x Testículo Não Descido}

A partir da análise do gráfico de distâncias mostrado na Figura 5.10, podemos inferir que os genes MBTPS2 e CREBBP são alguns dos mais próximos, em termos de processos biológicos aos genes associados à Fenda Palatina.

(WANG et al., 2014) realizaram uma análise em que mutações no gene MBTPS2 foram 


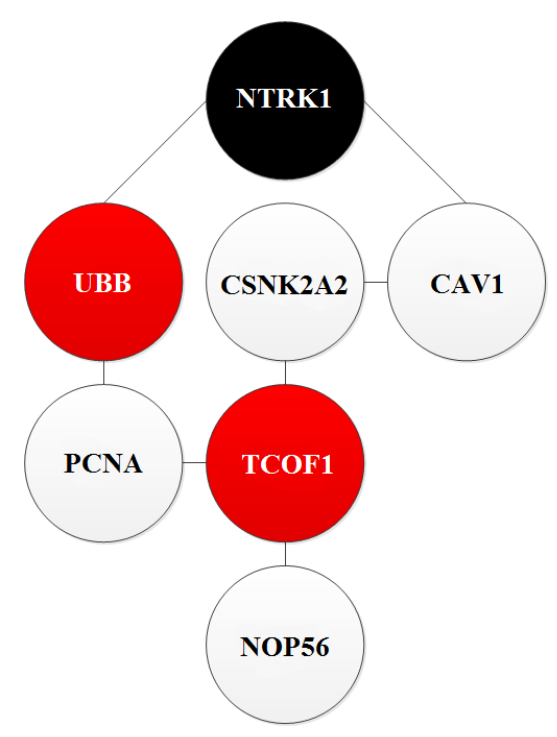

Figura 5.9: Via de interação entre os genes NTRK1, TCOF1, UBB.

associadas à causa de genodermatoses com BRESHECK (síndrome caracterizada por anomalias cerebrais, retardo mental, Displasia Ectodermal, Fenda Palatina e Criptorquismo, doença causada pelo Testículo Não Descido). Esta associação entre Fenda Palatina e o Criptorquismo, com relevância do gene MBTPS2 como ilustrado na Figura 5.10, vem a reforçar que o gene possa ser candidato à doença Fenda Palatina.

Além desta associação de doenças pela síndrome BRESHECK, a Síndrome RubensteinTaybi (RSTS) também é caracterizada pela desabilidade intelectual, anormalidades renais, defeitos congênitos da face, do coração e Criptorquismo. Os genes CREBBP e EP300 são os únicos genes atualmente conhecidos associados à RSTS.

(DEMEER et al., 2013) relataram uma delineação fenotípica e genotípica de 9 pacientes que apresentavam duplicação na região do gene CREBBP, com as seguintes características: Fenda Palatina, Úvula Bífida, Hérnia Inguinal e problemas oculares.

Desta forma, através de estudos de síndromes que apresentam diversas complicações comórbidas, podemos realizar a coleta de genes candidatos para cada complicação isolada e verificar se os mesmos realmente estão associados à doença em questão.

\subsubsection{Fenda Palatina x Espinha Bífida}

Observando o gráfico de distâncias mostrado na Figura 5.11 vemos o gene VANGL2, associado à doença da Espinha Bífida, próximo a genes da Fenda Palatina. Procuramos na literatura evidências que pudessem levar à associação do mesmo gene à Fenda Palatina. Em estudos como os de (LEI et al., 2013; LEI et al., 2014; KIBAR et al., 2010), os autores relatam a presença de mutações no gene VANGL2, em casos de defeitos de tubo neural, que inclui a Espinha Bífida. (YANG et al., 2014) analisaram a expressão dos genes PRICKLE2 e VANGL2 em pacientes filipinos que possuíam Fenda Palatina, com o objetivo de 


\section{Fenda Palatina x Testículo não descido}

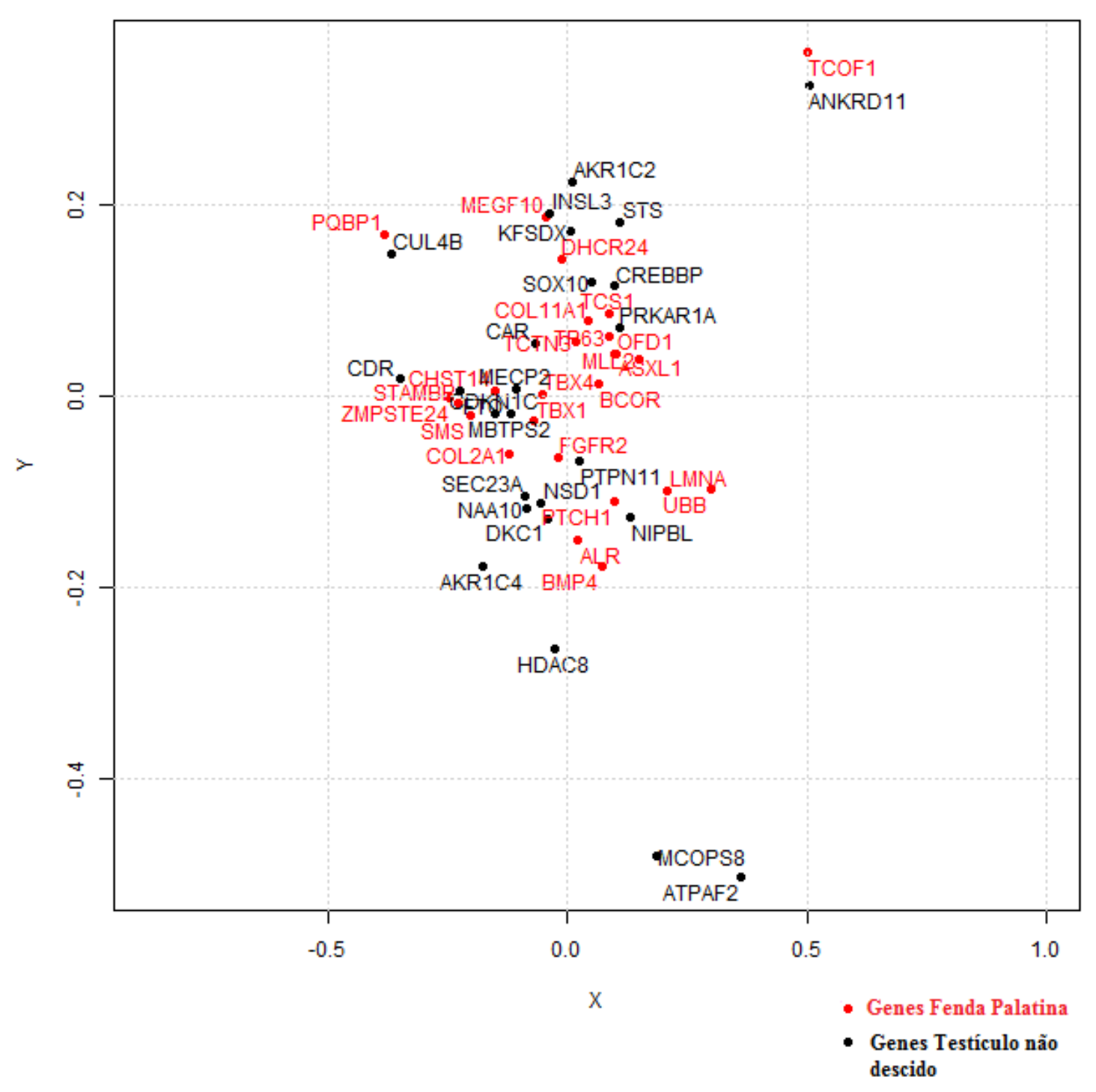

Figura 5.10: Visualização Bidimensional de distâncias entre os genes relacionados à Fenda Palatina e Testículo Não Descido.

identificar genes causadores da doença. Porém, somente o gene PRICKLE2 foi associado diretamente à morfogênese do palato. Logo, vemos que o gene VANGL2 possivelmente não possui associação à Fenda Palatina.

Além do gene VANGL2, podemos observar a alta proximidade do gene FUZ com o grupo de genes de Fenda Palatina. (JURILOFF; HARRIS, 2012) mostraram que mutações em genes de polaridade celular planar (PCP- estruturas de polarização e funções de células epiteliais que trabalham ao longo do plano dos tecidos) podem causar uma variedade de defeitos incluindo defeitos no tubo neural, como a Espinha Bífida. Dentre estes genes podemos incluir o gene FUZ. (ZHANG et al., 2011) relataram que a expressão deste gene primeiramente aparece em tubos dorsais e por último em tecidos ventrais e regiões craniofaciais, durante o 
desenvolvimento embrionário. Mutações neste gene exibem deformidades craniofaciais como ausência da língua, mandíbula hipoplásica e a Fenda Palatina. Ambos os estudos mostram como o gene FUZ pode trabalhar tanto em processos relacionados ao desenvolvimento do tubo neural como também no desenvolvimento craniofacial, favorecendo fenótipos como a Espinha Bífida e a Fenda Palatina. Assim, podemos validar o compartilhamento de mutações neste gene entre o par morbidade-comorbidade estudado.

\section{Fenda Palatina x Espinha Bífida}

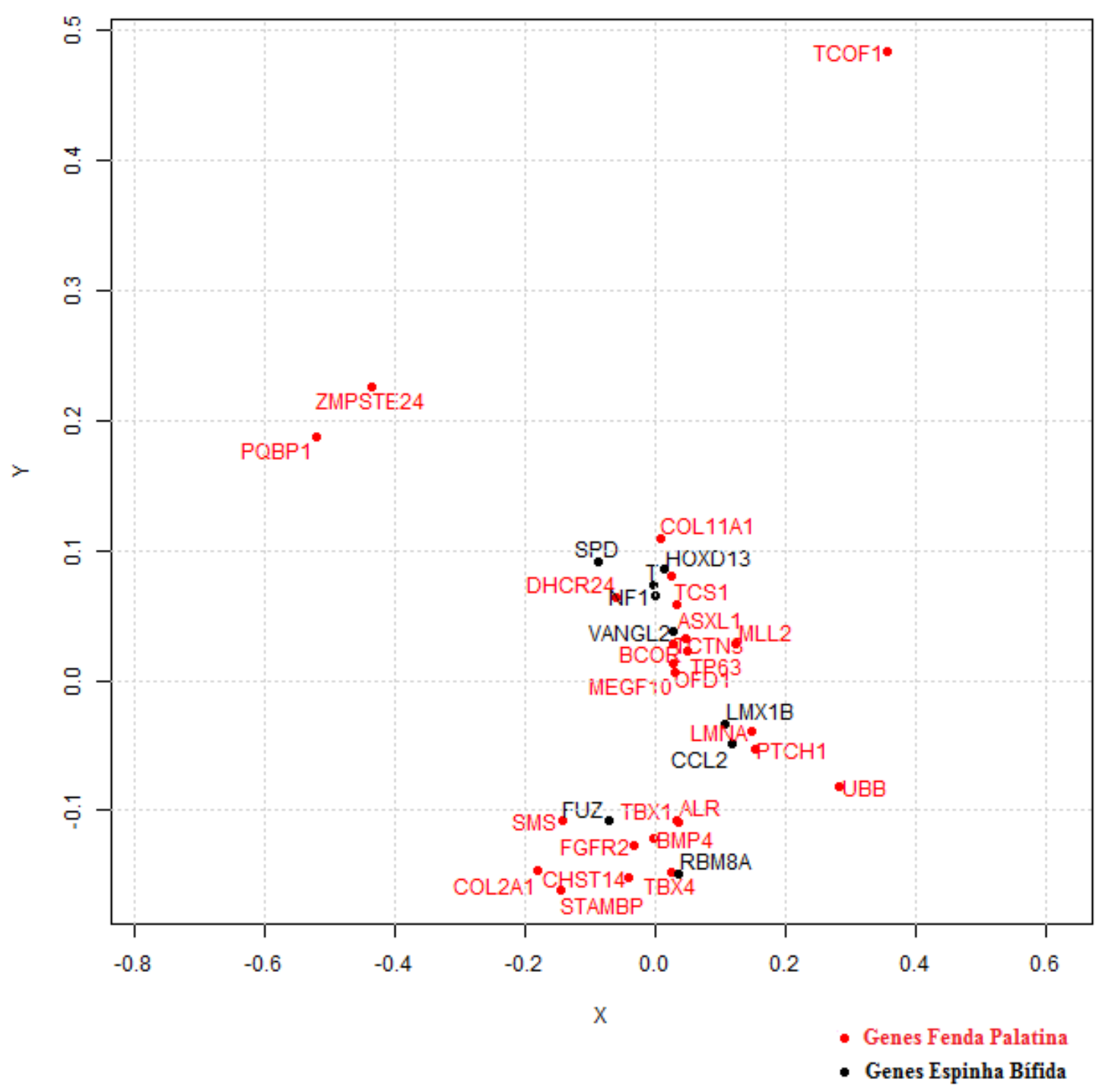

Figura 5.11: Visualizaçẫo Bidimensional de distâncias entre os genes relacionados à Fenda Palatina e Espinha Bifida.

\subsubsection{Fenda Palatina x Polidactilia}

Um dos genes associados à Polidactilia, conforme ilustração gráfica da Figura 5.12, é o TFAP2A. Tal gene é relatado por (MARTINELLI et al., 2011) como responsável pelo 
desenvolvimento orofacial e um ótimo candidato para Fenda Labial com ou sem Fenda Palatina. (STOETZEL et al., 2009) confirmaram o envolvimento do mesmo gene na Síndrome Branquia-Óculo-Facial (BOFS), sendo que a mesma apresenta como principais características anomalias oculares, Polidactilia e a Fenda Palatina.

Fenda Palatina x Polidactilia

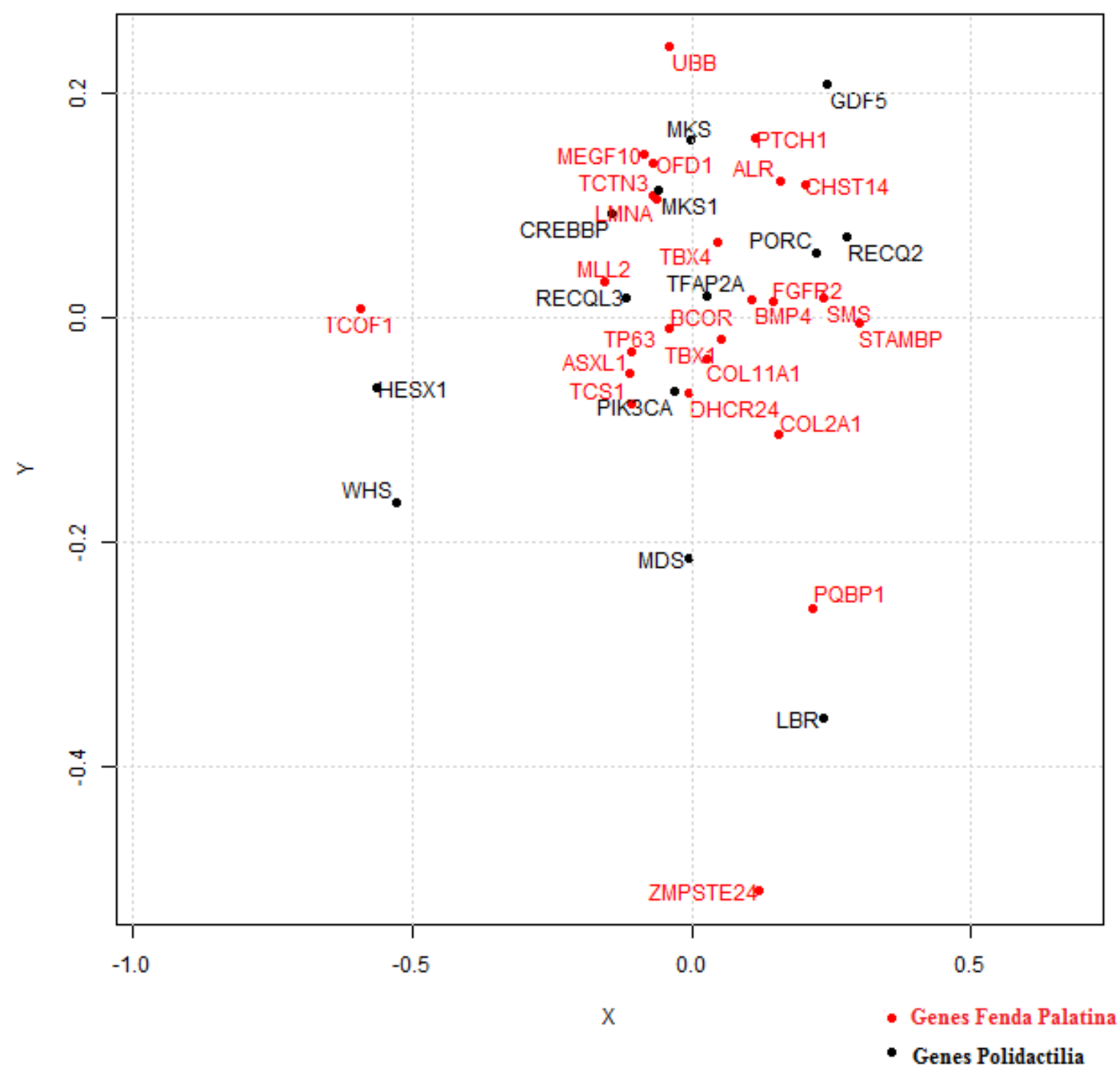

Figura 5.12: Visualização Bidimensional de distâncias entre os genes relacionados à Fenda Palatina e Polidactilia.

A Figura 5.13 ilustra a via de interação do gene TFAP2A com genes associados à Fenda Palatina, que mostra a possibilidade de interação entre estes genes, favorecendo a comorbidade e promovendo o gene como candidato à Fenda Palatina. 


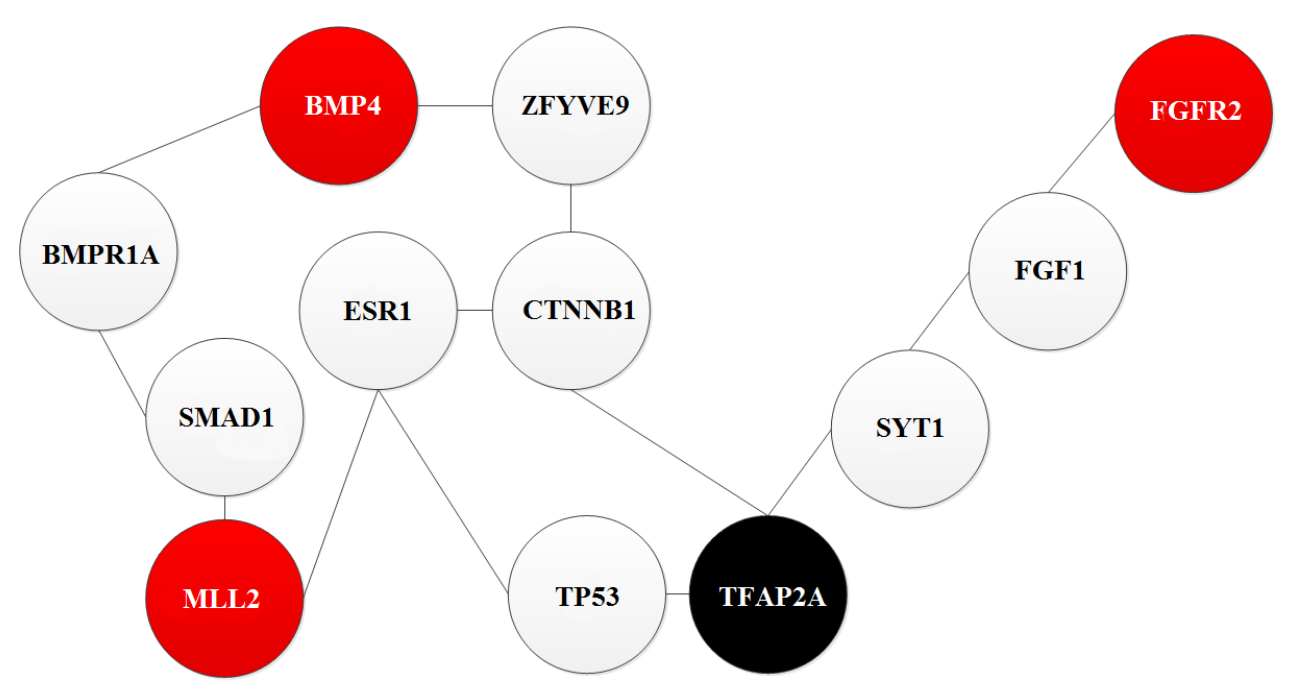

Figura 5.13: Via de interação entre os genes TFAP2A e os associados à Fenda Palatina.

\subsubsection{Fenda Palatina $\mathrm{x}$ Sindactilia}

Um dos genes observados no gráfico da Figura 5.14, que está associado à Sindactilia, é o GLI3. Tal gene foi analisado por (JAMSHEER et al., 2012), estudo que retrata o quanto mutações neste podem estar relacionadas a diversos fenótipos diferentes. A Síndrome Cefalopolisindactilia de Greg é uma doença rara autossômica dominante, causada por mutações no gene GLI3. Esta síndrome se caracteriza principalmente por anormalidades craniofaciais (macrocefalia e hipotelorismo) e malformações do membro como a Sindactilia. (HUANG et al., 2008) observaram uma alta incidência de Fenda Palatina em ratos com presença de mutações no gene GLI3, fato que contribui para a relação de mutações neste gene com a Fenda Palatina.

Além do gene GLI3, o gene ROR2 foi relatado por (LV et al., 2009) como sendo responsável pela Sindactilia em uma população de chineses e por causar a síndrome de Robinow, que apresenta dentre outros sintomas, a Fenda Palatina e a Sindactilia.

Esta análise evidencia que síndromes que apresentam diversas complicações como as citadas acima podem contribuir para a busca de genes candidatos dessas complicações isoladas.

\subsection{Discussão dos Resultados}

Como discussão dos resultados apresentados neste capítulo, temos de ser capazes de responder às perguntas realizadas na construção dos objetivos do projeto.

A partir do método construído, conseguimos realizar uma análise de integração de comorbidades presentes nos registros de internações hospitalares que constituem o SIH do SUS com os dados gênicos das mesmas comorbidades. Por meio dos pares de doenças de diagnóstico principal e secundário, fomos capazes então de coletar genes candidatos para 


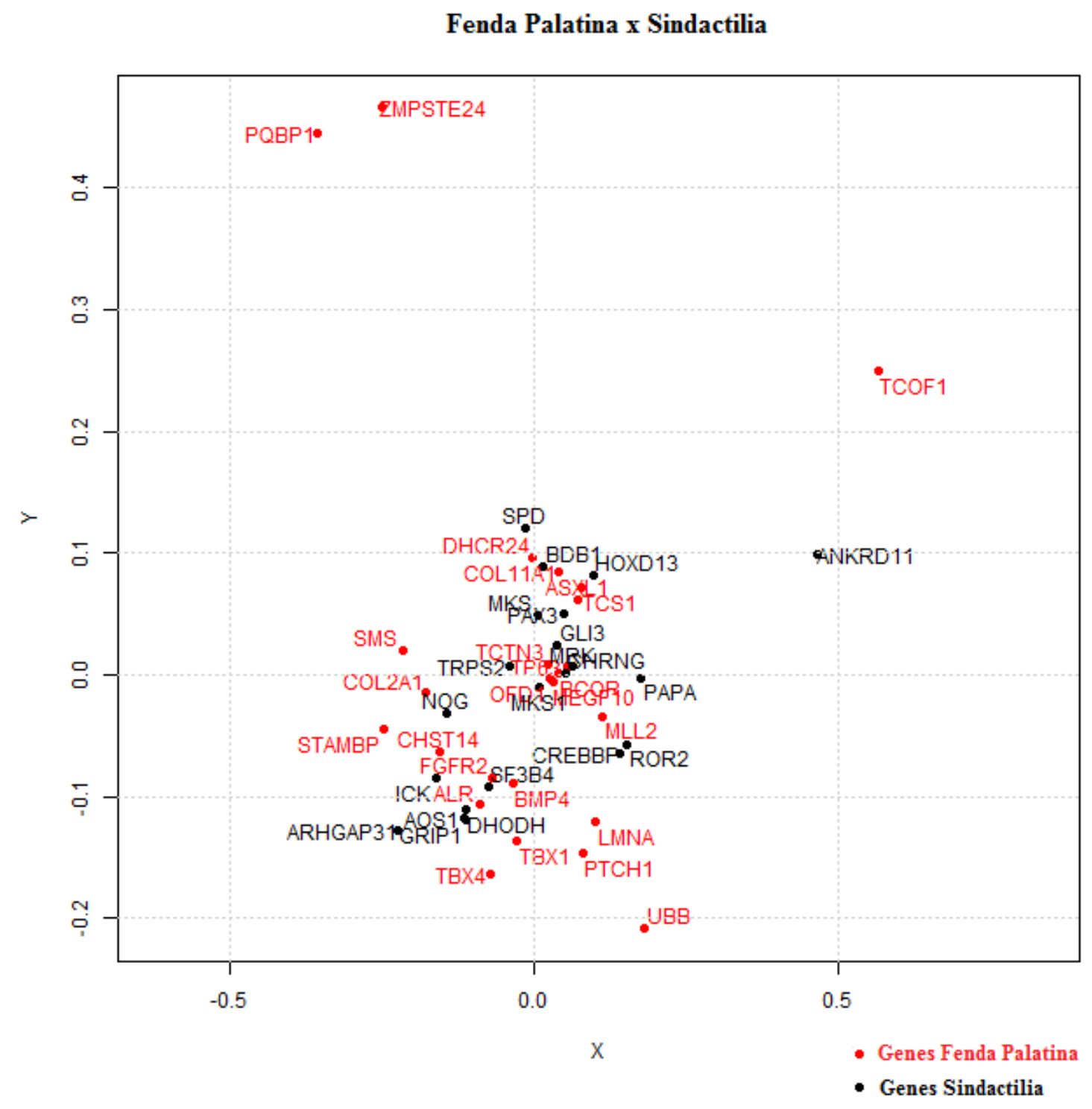

Figura 5.14: Visualização Bidimensional de distância entre os genes relacionados à Fenda Palatina e Sindactilia.

cada uma das doenças que compõem esses diagnósticos. Posteriormente, foi possível realizar uma análise desses dois conjuntos de genes a fim de introduzir mais genes candidatos a cada doença. Isto foi feito através da seleção de evidências em buscas na literatura e análise de vias de interação dos genes que compõem ambos os conjuntos de candidatos dessas doenças.

Analisando os achados de genes candidatos através das evidências encontradas após o processamento de coleta de genes de cada doença que forma par morbidade-comorbidade estudado, obtivemos resultados considerados relevantes. Casos como o do Autismo e da Macrocefalia, onde há evidências da literatura que sinalizam o compartilhamento de mutações no gene PTEN, comprovam a precisão do método desenvolvido neste projeto, onde podemos ver através do gráfico final de distâncias que há claramente o compartilhamento deste gene 
candidato para ambas as doenças.

Em outros casos como o da Esquizofrenia e Autismo, vimos que alguns genes candidatos a uma doença participam de vias de interação com os genes candidatos a outra doença, comprovando o efeito pleiotrópico afirmado na Seção 2.1 deste documento. Assim podemos inferir que a mutação em um gene pode afetar funções de outros genes que compartilham vias entre eles, podendo favorecer o aparecimento de pares morbidade-comorbidade.

Outro resultado significativo foi que alguns genes, coletados como responsáveis por uma doença, também apresentaram evidências através da literatura de serem responsáveis por outra doença que forma o par morbidade-comorbidade.

Não pudemos validar a presença da comorbidade nos registros de internação hospitalar do par de doenças Macrocefalia e Autismo. Não houve registro deste, nem na base remanescente após a filtragem, nem na base completa de registros de internações. Tal ausência não significa que o corte realizado na base de dados é incorreto, porém uma análise mais profunda precisa ser realizada.

Quanto às comorbidades coletadas na literatura referentes à Fenda Palatina, não foi possível encontrar registros nas internações hospitalares de pares de doenças de Fenda Palatina com Trissomias dos cromossomos 13, 18, 21 e a Holoprosencefalia. Tal ausência de registros para o estudo de comorbidades se deve ao fato de que estas doenças são muito raras na população. As Trissomias do 13 e 18, por exemplo, apresentam incidência de nativivos de 1 em 10.000 , sendo que $50 \%$ das crianças afetadas morrem na primeira semana e a sobrevida além de 1 ano é muito incomum.

Desse modo, podemos inferir que o estudo de comorbidades através de evidências de internações hospitalares não é apropriado a casos como os relatados acima, em que as complicações são raras e a sobrevida de indivíduos com as mesmas é incomum. 


\section{Capítulo 6}

\section{Considerações Finais}

Este capítulo sintetiza as conclusões que foram obtidas através da aplicação deste projeto de pesquisa, dificuldades encontradas ao longo de seu desenvolvimento e alguns pontos imprescendíveis na realização de trabalhos futuros.

\subsection{Conclusões}

Através do método proposto e dos resultados encontrados por meio dos estudos de validação e estudos de casos, podemos concluir que a análise gênica de comorbidades pode ser relevante para métodos de predição de genes candidatos.

Os resultados mostram que mutações de genes podem ser compartilhadas entre pares de morbidade-comorbidade, além de apresentarem evidência de que a ação de uma mutação gênica pode interferir na função de outros genes que participam da mesma via de interação. Esta interferência pode justificar a presença de comorbidades altas dentre internações hospitalares.

O método proposto confirma que a abordagem de coleta de genes candidatos através do estudo de comorbidades é efetiva. Ela também pode ser relevante como uma coleta abrangente de genes responsáveis por doenças, que leva em consideração dados da literatura, compostos pela comunidade científica e que foram analisados através do projeto OMIM. Sendo assim, o método proposto serve como integrador desses dados epidemiológicos e genéticos, otimizando o trabalho manual de profissionais da saúde que desejam estudar e analisar quais genes já foram relacionados para uma determinada doença.

\subsection{Dificuldades Encontradas}

Uma dificuldade encontrada durante a execução deste projeto foi a especificidade de codificação entre fontes de vocabulários biomédicos. No início do projeto foi proposto realizar 
o mapeamento entre as classificações do CID-10 e os genes OMIM através de ferramentas de mineração de textos científicos. Porém, as classificações das doenças apresentam nomes muito específicos que não são os mesmos nomes de doenças preferidos dentre a comunidade científica, o que dificultou a coleta de genes. Este fato nos levou a utilizar o mapeamento CID-10-OMIM através da ferramenta do Metatesauros da UMLS.

Dificuldades encontradas relacionadas a doenças raras, como as relatadas no Capítulo 5, mostram que o método de análise de comorbidades através de registros de internações hospitalares pode não ser apropriado.

Outra dificuldade encontrada neste projeto foi em relação a estrutura dos registros da base de dados de internações hospitalares. Os registros de internações apresentam somente 2 diagnósticos, limitação que dificulta o estudo de comorbidades múltiplas.

\subsection{Trabalhos Futuros}

Como estamos trabalhando com dados públicos do Brasil, as informações são anônimas, ou seja, não temos as informações de mais de uma internação por paciente, dado relevante para o rastreamento de outros diagnósticos que o paciente pode apresentar em uma linha de tempo contínua.

Como trabalho futuro, pretendemos realizar o relacionamento probabilístico destes registros, com o objetivo de unificar as internações hospitalares por pacientes. Desta forma, abrangeremos mais diagnósticos na composição das comorbidades.

Além disto, para refinar a metodologia, será feita uma análise de distribuição dos valores de comorbidades obtidos na fase anterior de filtragem dos registros de internações. Com base nesta análise, será feita uma escolha apropriada ao corte de cormorbidade.

Para aprimorar os resultados, serão aplicados métodos estatísticos de distância para contribuir na análise de proximidade de diferentes genes que possam estar associados e que auxiliem na predição gênica. 


\section{Apêndice A}

\section{Laudo AIH}

A Figura A.1 representa o laudo a ser preenchido pelos profissionais de saúde para a solicitação de autorização de internação hospitalar. O sistema de internações hospitalares (SIH) é alimentado pelas informações desse documento. Nota-se que o mesmo apresenta mais que um campo de CID-10 e CID-10 de causas associadas. Porém os dados disponibilizados ao público através do (DATASUS, 2014) são dados da AIH reduzida, ou seja, não apresentam alguns dados que são preenchidos nesse documento. Desta forma, apenas permanecemos com as informações preenchidas nos campos de CID-10 principal e CID-10 secundário. Algumas informações que alimentam o SIH como valor do procedimento ou datas de entrada e saída do paciente são cruzadas através de outras fontes de documentações e do número do prontuário do paciente. 


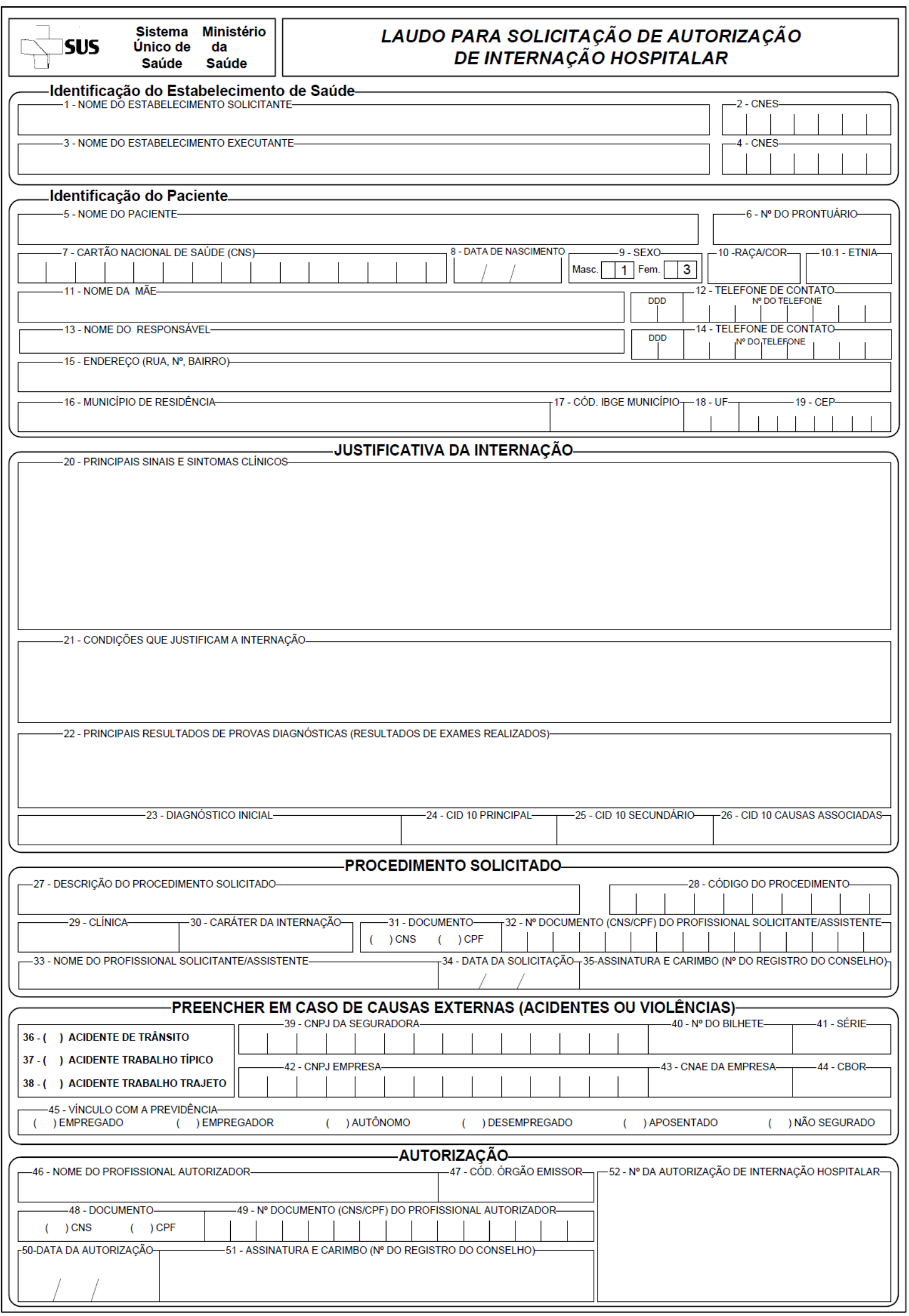

Figura A.1: Laudo de Solicitação de Autorização de Internação Hospitalar. 


\section{Referências Bibliográficas}

AERTS, S. et al. Gene prioritization through genomic data fusion. Nat. Biotechnol., Nature Publishing Group, v. 24, n. 5, p. 537-544, May 2006.

ALROMAIH, S. et al. CD8A gene polymorphisms predict severity factors in chronic rhinosinusitis. International Forum of Allergy and Rhinology, Wiley-Blackwell, v. 3, n. 8, p. 605-611, Aug 2013.

ANDRIEUX, J. et al. Genotype phenotype correlation of 30 patients with Smith-Magenis syndrome (SMS) using comparative genome hybridisation array: cleft palate in SMS is associated with larger deletions. J. Med. Genet., BMJ, v. 44, n. 8, p. 537-540, Aug 2007.

ASHBURNER, M. et al. Gene ontology: tool for the unification of biology. The Gene Ontology Consortium. Nat. Genet., Nature Publishing Group, v. 25, n. 1, p. 25-29, May 2000 .

AVILA, J. R. et al. PVRL1 variants contribute to non-syndromic cleft lip and palate in multiple populations. American Journal of Medical Genetics Part A, Wiley-Blackwell, v. 140, n. 23 , p. $2562-2570$, Dec 2006.

BARABASI, A. L.; GULBAHCE, N.; LOSCALZO, J. Network medicine: a network-based approach to human disease. Nat. Rev. Genet., Nature Publishing Group, v. 12, n. 1, p. 56-68, Jan 2011.

BEATY, T. H. et al. A genome-wide association study of cleft lip with and without cleft palate identifies risk variants near MAFB and ABCA4. Nat. Genet., Nature Publishing Group, v. 42, n. 6, p. 525-529, Jun 2010.

BECKER, K. G. The common variants/multiple disease hypothesis of common complex genetic disorders. Medical Hypotheses, Elsevier BV, v. 62, n. 2, p. 309-317, 2004.

BIRNBAUM, S. et al. Key susceptibility locus for nonsyndromic cleft lip with or without cleft palate on chromosome 8q24. Nat. Genet., Nature Publishing Group, v. 41, n. 4, p. 473-477, Apr 2009.

BODENREIDER, O. The unified medical language system (UMLS): integrating biomedical terminology. Nucleic Acids Research, Oxford University Press (OUP), v. 32, n. 90001, p. 267D-270, Jan 2004.

BROMBERG, Y. Chapter 15: disease gene prioritization. PLoS Comput. Biol., Public Library of Science (PLoS), v. 9, n. 4, p. e1002902, Apr 2013.

CAMPOS, M. L. A. O papel das definições na pesquisa em ontologia. Perspect. ciênc. inf., FapUNIFESP (SciELO), v. 15, n. 1, p. 220-238, Apr 2010. 
CARROLL, J.; CHANG, J.-J. Analysis of individual differences in multidimensional scaling via an n-way generalization of eckart-young decomposition. Psychometrika, Springer-Verlag, v. 35, n. 3, p. 283-319, 1970.

CLIPPERTON-ALlEN, A. E.; PAGE, D. T. Pten haploinsufficient mice show broad brain overgrowth but selective impairments in autism-relevant behavioral tests. Hum. Mol. Genet., Oxford University Press (OUP), v. 23, n. 13, p. 3490-3505, Jul 2014.

DATASUS. 2014. <http://www.datasus.gov.br/catalogo/sihsus.htm>. Último acesso em $28 / 07 / 2014$.

DEMEER, B. et al. Duplication 16p13.3 and the CREBBP gene: confirmation of the phenotype. European Journal of Medical Genetics, Elsevier BV, v. 56, n. 1, p. 26-31, Jan 2013.

DEMLO, L. K.; CAMPBELL, P. M.; BROWN, S. S. Reliability of information abstracted from patients' medical records. Med Care, Lippincott Williams Wilkins, v. 16, n. 12, p. 995-1005, Dec 1978.

DIXON, M. J. et al. Cleft lip and palate: understanding genetic and environmental influences. Nat. Rev. Genet., Nature Publishing Group, v. 12, n. 3, p. 167-178, Mar 2011.

Entrez. 2014. <http://www.ncbi.nlm.nih.gov/Entrez>. Último acesso em 28/07/2014.

GADOLA, S. D. et al. TAP deficiency syndrome. Clin. Exp. Immunol., Wiley-Blackwell, v. 121, n. 2, p. 173-178, Aug 2000.

GADOW, K. D. Association of schizophrenia spectrum and autism spectrum disorder (ASD) symptoms in children with ASD and clinic controls. Res Dev Disabil, Elsevier BV, v. 34, n. 4, p. 1289-1299, Apr 2013.

GAO, L. et al. Oral and craniofacial manifestations and two novel missense mutations of the NTRK1 gene identified in the patient with congenital insensitivity to pain with anhidrosis. PLoS ONE, Public Library of Science (PLoS), v. 8, n. 6, p. e66863, 2013.

GOH, K. I.; CHOI, I. G. Exploring the human diseasome: the human disease network. Brief Funct Genomics, Oxford University Press (OUP), v. 11, n. 6, p. 533-542, Nov 2012.

GOH, K. I.; CUSICK, M. E. The human disease network. Proc Natl Acad Sci USA, Proceedings of the National Academy of Sciences, v. 104, n. 21, p. 8685-8690, 2007.

GOINES, P. E. et al. Increased midgestational IFN-g, IL-4 and IL-5 in women bearing a child with autism: A case-control study. Mol Autism, Springer Science + Business Media, v. 2, n. 1, p. 13, 2011.

GRANT, S. F. et al. A genome-wide association study identifies a locus for nonsyndromic cleft lip with or without cleft palate on 8q24. The Journal of Pediatrics, Elsevier BV, v. 155, n. 6, p. 909-913, Dec 2009.

GREWAL, J. et al. Maternal periconceptional smoking and alcohol consumption and risk for select congenital anomalies. Birth Defects Res. Part A Clin. Mol. Teratol., Wiley-Blackwell, v. 82, n. 7, p. 519-526, Jul 2008.

GROSEN, D. et al. Risk of oral clefts in twins. Epidemiology, Ovid Technologies (Wolters Kluwer Health), v. 22, n. 3, p. 313-319, May 2011. 
GUDIVADA, R. C. C. et al. Identifying disease-causal genes using semantic webbased representation of integrated genomic and phenomic knowledge. Journal of biomedical informatics, Elsevier BV, v. 41, n. 5, p. 717-729, Oct 2008.

HALLERBACK, M. U.; LUGNEGARD, T.; GILLBERG, C. Is autism spectrum disorder common in schizophrenia? Psychiatry Res, Elsevier BV, v. 198, n. 1, p. 12-17, Jun 2012.

HAN, G. B.; MARC, A. D. Opinion: From syndrome families to functional genomics. Nat Rev Genet, Nature Publishing Group, v. 5, n. 7, p. 545-551, Jul 2004.

HAYFLICK, S. J. et al. Beta-Propeller protein-associated neurodegeneration: a new X-linked dominant disorder with brain iron accumulation. Brain, Oxford University Press (OUP), v. 136, n. Pt 6, p. 1708-1717, Jun 2013.

HIDALGO, C. A. et al. A dynamic network approach for the study of human phenotypes. PLoS Comput. Biol., Public Library of Science (PLoS), v. 5, n. 4, p. e1000353, Apr 2009.

HODGKIN, J. Seven types of pleiotropy. Int. J. Dev. Biol., v. 42, n. 3, p. 501-505, 1998.

HUANG, X. et al. GLI3-deficient mice exhibit cleft palate associated with abnormal tongue development. Developmental Dynamics, Wiley-Blackwell, v. 237, n. 10, p. 3079-3087, Oct 2008 .

HYON, C. et al. A new 17p13.3 microduplication including the PAFAH1B1 and YWHAE genes resulting from an unbalanced X;17 translocation. European Journal of Medical Genetics, Elsevier BV, v. 54, n. 3, p. 287-291, 2011.

IKEDA, T. et al. Association analysis of single nucleotide polymorphisms in cartilagespecific collagen genes with knee and hip osteoarthritis in the japanese population. Journal of Bone and Mineral Research, Wiley-Blackwell, v. 17, n. 7, p. 1290-1296, Jul 2002.

JAMSHEER, A. et al. Expanded mutational spectrum of the GLI3 gene substantiates genotype-phenotype correlations. J Appl Genetics, Springer Science + Business Media, v. 53, n. 4, p. 415-422, Nov 2012.

JEZEWSKI, P. A. et al. Complete sequencing shows a role for MSX1 in non-syndromic cleft lip and palate. Journal of Medical Genetics.

JONES, S. et al. Molecular correlates of sleep and wakefulness in the brain of the white-crowned sparrow. Journal of Neurochemistry, Wiley-Blackwell, v. 105, n. 1, p. 46-62, Apr 2008.

JUGESSUR, A. et al. X-linked genes and risk of orofacial clefts: evidence from two population-based studies in Scandinavia. PLoS ONE, Public Library of Science (PLoS), v. 7, n. 6 , p. e39240, 2012.

JURILOFF, D. M.; HARRIS, M. J. A consideration of the evidence that genetic defects in planar cell polarity contribute to the etiology of human neural tube defects. Birth Defects Research Part A: Clinical and Molecular Teratology, Wiley-Blackwell, v. 94, n. 10, p. 824-840, Oct 2012.

KIBAR, Z. et al. Contribution of VANGL2 mutations to isolated neural tube defects. Clinical Genetics, Wiley-Blackwell, v. 80, n. 1, p. 76-82, Jul 2010. 
KIM, H. J. et al. Roles of interferon-gamma and its target genes in schizophrenia: Proteomics-based reverse genetics from mouse to human. Proteomics, Wiley-Blackwell, v. 12, n. 11, p. 1815-1829, Jun 2012.

KIM, Y.-A.; WUCHTY, S.; PRZYTYCKA, T. M. Identifying causal genes and dysregulated pathways in complex diseases. PLoS Computational Biology, Public Library of Science (PLoS), v. 7, n. 3, p. e1001095, Mar 2011.

KING, C. L. B. H. Is schizophrenia on the autism spectrum? Brain Research, Elsevier BV, v. 1380, n. 0, p. 34 - 41, 2011. The Emerging Neuroscience of Autism Spectrum Disorders.

KOHLI, S. S.; KOHLI, V. S. A comprehensive review of the genetic basis of cleft lip and palate. J Oral Maxillofac Pathol, Medknow, v. 16, n. 1, p. 64-72, Jan 2012.

KROM, M. et al. A common variant in DRD3 receptor is associated with autism spectrum disorder. Biol. Psychiatry, Elsevier BV, v. 65, n. 7, p. 625-630, Apr 2009.

LEBRAO, M. L. Análise da fidedignidade dos dados estatísticos hospitalares disponíveis na secretaria de estado da são paulo em 1974. Revista de Saúde Pública, scielo, v. 12, p. 234 249, 061978.

LEE, D. S. et al. The implications of human metabolic network topology for disease comorbidity. Proceedings of the National Academy of Sciences, Proceedings of the National Academy of Sciences, v. 105, n. 29, p. 9880-9885, Jul 2008.

LEI, Y. et al. Mutations in planar cell polarity gene SCRIB are associated with spina bifida. PLoS ONE, Public Library of Science (PLoS), v. 8, n. 7, p. e69262, Jul 2013.

LEI, Y. et al. Identification of novel CELSR1 mutations in spina bifida. PLoS ONE, Public Library of Science (PLoS), v. 9, n. 3, p. e92207, Mar 2014.

LESNICK, T. G. et al. A genomic pathway approach to a complex disease: axon guidance and Parkinson disease. PLoS Genet., Public Library of Science (PLoS), v. 3, n. 6, p. e98, Jun 2007.

LEWIS, S. E. Gene Ontology: looking backwards and forwards. Genome Biol., Springer Science + Business Media, v. 6, n. 1, p. 103, 2005.

LIN, D. An information-theoretic definition of similarity. In: Proceedings of the Fifteenth International Conference on Machine Learning. San Francisco, CA, USA: Morgan Kaufmann Publishers Inc., 1998. (ICML '98), p. 296-304. ISBN 1-55860-556-8.

LV, D. et al. A novel single-base deletion in ROR2 causes atypical brachydactyly type B1 with cutaneous syndactyly in a large chinese family. J Hum Genet, Nature Publishing Group, v. 54, n. 7, p. 422-425, May 2009.

MANGOLD, E. et al. Genome-wide association study identifies two susceptibility loci for nonsyndromic cleft lip with or without cleft palate. Nat Genet, Nature Publishing Group, v. 42, n. 1, p. 24-26, Jan 2010.

Manual-UMLS. 2014. <http://www.ncbi.nlm.nih.gov/books/NBK9676/>. Último acesso em $28 / 07 / 2014$. 
MARTINELLI, M. et al. Evidence of an involvement of TFAP2A gene in non-syndromic cleft lip with or without cleft palate: an Italian study. Int J Immunopathol Pharmacol, v. 24, n. 2 Suppl, p. 7-10, 2011.

MELKONIEMI, M. et al. Collagen XI sequence variations in nonsyndromic cleft palate, Robin sequence and micrognathia. Eur. J. Hum. Genet., Nature Publishing Group, v. 11, n. 3, p. 265-270, Mar 2003.

MENDES; PN. Uma abordagem para a construção e uso de ontologias no suporte à integração e análise de dados genômicos. Instituto de Matemática/NCE da UFRJ., 2005.

MEYRE, D. et al. Variants of ENPP1 are associated with childhood and adult obesity and increase the risk of glucose intolerance and type 2 diabetes. Nat Genet, Nature Publishing Group, v. 37, n. 8, p. 863-867, Aug 2005.

MUNGER, R. G. et al. Maternal alcohol use and risk of orofacial cleft birth defects. Teratology, v. 54, n. 1, p. 27-33, Jul 1996.

NETO, K. F. et al. Desenvolvimento de uma Metodologia para Análise Gênica de Comorbidades a Partir da Integração de Dados Epidemiológicos. XII Workshop de Informática Médica, 2012.

NIKOPENSIUS, T. et al. Susceptibility locus for non-syndromic cleft lip with or without cleft palate on chromosome 10q25 confers risk in Estonian patients. European Journal of Oral Sciences, Wiley-Blackwell, v. 118, n. 3, p. 317-319, Jun 2010.

OMIM. 2014. <http://www.ncbi.nlm.nih.gov/omim>. Último acesso em 28/07/2014.

OTI, M. Predicting disease genes using protein-protein interactions. Journal of Medical Genetics, BMJ, v. 43, n. 8, p. 691-698, Aug 2006.

PANIZZI, J. R. et al. CCDC103 mutations cause primary ciliary dyskinesia by disrupting assembly of ciliary dynein arms. Nat. Genet., Nature Publishing Group, v. 44, n. 6, p. 714-719, Jun 2012.

PASCHUAlinOtO, A. L.; AMARAL, T. M. Discinesia ciliar primária: um caso atípico. Revista Unilus Ensino e Pesquisa, Revista Lusiada, v. 7, n. 12, p. 5-10, Jan 2010.

PESQUITA, C. et al. Metrics for go based protein semantic similarity: a systematic evaluation. BMC Bioinformatics, Springer Science + Business Media, v. 9, n. Suppl 5, p. S4, 2008.

PESQUITA, C. et al. Semantic similarity in biomedical ontologies. PLoS Comput. Biol., Public Library of Science (PLoS), v. 5, n. 7, p. e1000443, Jul 2009.

PIRO, R. M.; CUNTO, F. D. Computational approaches to disease-gene prediction: rationale, classification and successes. FEBS J., Wiley-Blackwell, v. 279, n. 5, p. 678-696, Mar 2012.

PRASAD, T. S. K. et al. Human protein reference database-2009 update. Nucleic Acids Research, Oxford University Press (OUP), v. 37, n. Database, p. D767-D772, Jan 2009.

Python. 2014. <http://www.python.org.br/>. Último acesso em 28/07/2014.

R. 2014. <http://www.r-project.org/>. Último acesso em 28/07/2014. 
RAHIMOV, F. et al. Disruption of an ap- $2 \alpha$ binding site in an irf6 enhancer is associated with cleft lip. Nat Genet, Nature Publishing Group, v. 40, n. 11, p. 1341-1347, Nov 2008.

RAPP, M. et al. Severe complications in wound healing and fracture treatment in two brothers with congenital insensitivity to pain with anhidrosis. Journal of Pediatric Orthopaedics B, Ovid Technologies (Wolters Kluwer Health), v. 22, n. 1, p. 76-80, Jan 2013.

RESNIK, P. Using information content to evaluate semantic similarity in a taxonomy. In: Proceedings of the 14th International Joint Conference on Artificial Intelligence - Volume 1. [S.l.]: Morgan Kaufmann Publishers Inc., 1995. (IJCAI'95), p. 448-453.

RILEY, B. M. et al. Impaired FGF signaling contributes to cleft lip and palate. Proceedings of the National Academy of Sciences, Proceedings of the National Academy of Sciences, v. 104, n. 11, p. 4512-4517, Mar 2007.

ROJAS-MARTINEZ, A. et al. Genetic risk factors for nonsyndromic cleft lip with or without cleft palate in a Mesoamerican population: Evidence for IRF6 and variants at 8q24 and 10q25. Birth Defects Research Part A: Clinical and Molecular Teratology, Wiley-Blackwell, v. 88, n. 7, p. 535-537, Jul 2010.

ROMIO, L. et al. OFD1 is a centrosomal/basal body protein expressed during mesenchymal-epithelial transition in human nephrogenesis. J. Am. Soc. Nephrol., American Society of Nephrology (ASN), v. 15, n. 10, p. 2556-2568, Oct 2004.

ROOIJ, I. A. van et al. Smoking, genetic polymorphisms in biotransformation enzymes, and nonsyndromic oral clefting: a gene-environment interaction. Epidemiology, v. 12, n. 5, p. 502-507, Sep 2001.

ROQUE, F. S. et al. Using electronic patient records to discover disease correlations and stratify patient cohorts. PLoS Computational Biology, Public Library of Science (PLoS), v. 7, n. 8, p. e1002141, Aug 2011.

SCAPOLI, L. et al. Genes causing clefting syndromes as candidates for non-syndromic cleft lip with or without cleft palate: a family-based association study. European Journal of Oral Sciences, Wiley-Blackwell, v. 116, n. 6, p. 507-511, Dec 2008.

SCHUYLER, P. L. et al. The UMLS Metathesaurus: representing different views of biomedical concepts. Bull Med Libr Assoc, v. 81, n. 2, p. 217-222, Apr 1993.

SIVAKUMARAN, S. et al. Abundant pleiotropy in human complex diseases and traits. Am. J. Hum. Genet., Elsevier BV, v. 89, n. 5, p. 607-618, Nov 2011.

STEVENSON, R. E.; HALL, J. G.; GOODMAN, R. M. Human malformations and related anomalies. Oxford University Press, BMJ, v. 92, n. 3, p. 280-280, Mar 1993.

STOETZEL, C. et al. Confirmation of TFAP2A gene involvement in branchio-oculo-facial syndrome (BOFS) and report of temporal bone anomalies. American Journal of Medical Genetics Part A, Wiley-Blackwell, v. 149A, n. 10, p. 2141-2146, Oct 2009.

SUN, J. et al. A multi-dimensional evidence-based candidate gene prioritization approach for complex diseases-schizophrenia as a case. Bioinformatics, Oxford University Press (OUP), v. 25, n. 19, p. 2595-6602, Oct 2009. 
TURHANI, D. et al. Mutation analysis of CLPTM 1 and PVRL 1 genes in patients with non-syndromic clefts of lip, alveolus and palate. Journal of Cranio-Maxillofacial Surgery, Elsevier BV, v. 33, n. 5, p. 301-306, Oct 2005.

UMLS. 2014. <http://www.nlm.nih.gov/research/umls/>. Último acesso em 28/07/2014.

URRACA, N. et al. Association study of DRD3 gene in schizophrenia in Mexican sib-pairs. Psychiatry Res, Elsevier BV, v. 190, n. 2-3, p. 367-368, Dec 2011.

VERAS, C. M. T.; MARTINS, M. S. A confiabilidade dos dados nos formulários de autorização de internação hospitalar (AIH). Cadernos de Saúde Pública, Scielo, v. 10, p. 339 - 355, 091994.

WANG, H. J. et al. Recurrent splice-site mutation in MBTPS2 underlying ifap syndrome with olmsted syndrome-like features in a chinese patient. Clin Exp Dermatol, Wiley-Blackwell, v. 39, n. 2, p. 158-161, Mar 2014.

WU, L.; RUIZ, E. E. S. Estudo e aplicação de medidas de similaridade semântica na visualização das interações gênicas em esquizofrênia. WIM CSBC, 2012.

YANG, T. et al. Analysis of PRICKLE1 in human cleft palate and mouse development demonstrates rare and common variants involved in human malformations. Molecular Genetics Genomic Medicine, Wiley-Blackwell, v. 2, n. 2, p. 138-151, Mar 2014.

YU, G. et al. Gosemsim: an R package for measuring semantic similarity among go terms and gene products. Bioinformatics, Oxford University Press (OUP), v. 26, n. 7, p. 976-978, Apr 2010.

YU, S. et al. Gene prioritization and clustering by multi-view text mining. $B M C$ Bioinformatics, Springer Science + Business Media, v. 11, n. 1, p. 28, 2010.

ZHANG, Z. et al. FUZ regulates craniofacial development through tissue specific responses to signaling factors. PLoS ONE, Public Library of Science (PLoS), v. 6, n. 9, p. e24608, 2011. 